\title{
UK Renal Registry 11th Annual Report (December 2008): Chapter 10 Biochemistry profile of patients receiving dialysis in the UK in 2007: national and centre-specific analyses
}

\author{
Alex Hodsman ${ }^{\mathrm{a}}$, Edmund J Lamb ${ }^{\mathrm{b}}$, Retha Steenkamp ${ }^{\mathrm{a}}$ and Graham Warwick \\ ${ }^{\mathrm{a} U K}$ Renal Registry, Bristol, UK; ${ }^{\mathrm{b}}$ Kent \& Canterbury Hospital, Kent, UK; ' ${ }^{\mathrm{L}}$ eicester General Hospital, Leicester, UK
}

\section{Key Words}

Bicarbonate - Biochemical variables - Calcium - Cholesterol · Dialysis - Haemodialysis - Parathyroid hormone - Peritoneal Dialysis · Phosphate · Quality improvement

\begin{abstract}
Introduction: The UK Renal Association Clinical Practice Guidelines include clinical performance measures for biochemical parameters in dialysis patients [1]. The UK Renal Registry (UKRR) annually audits dialysis centre performance against these measures as part of its role in promoting continuous quality improvement. Methods: Cross sectional performance analyses were undertaken to compare dialysis centre achievement of clinical audit measures for prevalent haemodialysis (HD) and peritoneal dialysis (PD) cohorts in 2007. The biochemical variables studied were phosphate, adjusted calcium, parathyroid hormone, bicarbonate and total cholesterol. In addition longitudinal analyses were performed (2000-2007) to show changes in achievement of clinical performance measures over time. Results: Serum phosphate was between $1.1-1.8 \mathrm{mmol} / \mathrm{L}$ in $53 \%$ of HD and 64\% of PD patients. Since 2003 there has been annual improvement in phosphate control for both HD and PD patients, largely through a reduction in phosphate $>1.8 \mathrm{mmol} / \mathrm{L}$. PD patients this year also showed a reduction
\end{abstract}

\section{KARGER}

Fax +4161306 1234 E-Mail karger@karger.ch www.karger.com
C 2009 S. Karger AG, Basel

$1160-2110 / 09 / 1115-0185 \$ 26.00 / 0$

Accessible online at: www.karger.com/nec in the percentage with a low phosphate. Adjusted calcium was between $2.2-2.6 \mathrm{mmol} / \mathrm{L}$ in $73 \%$ of $\mathrm{HD}$ and $78 \%$ of PD patients. Parathyroid hormone was between 16-32 pmol/L in $25 \%$ of $\mathrm{HD}$ and $27 \%$ of PD patients. The audit measure for bicarbonate was achieved in $71 \%$ of $\mathrm{HD}$ and $50 \%$ of PD patients. There was inter-centre variation for all variables studied. Conclusions: The UKRR consistently demonstrates inter-centre variation in achievement of biochemical clinical audit measures. Understanding the causes of this variation is an important part of improving the care of dialysis patients in the UK.

\section{Introduction}

The UKRR collected routine biochemical data from clinical information systems in renal centres in England, Wales and Northern Ireland. Annual cross sectional analyses were undertaken on some of these variables to determine centre level performance against national (Renal Association) clinical performance measures. This enabled UK renal centres to compare their own performance against each other and to the UK average performance [2]. The UK Renal Association Clinical Practice Guidelines were revised and the final version 
of the 4th edition of these guidelines was published in November 2007 (although a draft version was available for some time prior to this) [1]. Audit data for 2007 therefore spanned the adoption of these guidelines which included revision of some of the audit measures. Audit measures for kidney disease increasingly include tighter specification limits in conjunction with a growing evidence base. Out of range observations (e.g. hyperphosphataemia and hypophosphataemia) needed to be interpreted cautiously as they may relate to different clinical problems or population characteristics. These will therefore require different strategies to improve centre performance of clinical audit measures. The format of data presentation has been revised compared to previous UKRR reports [2]. To supplement these performance analyses, summary statistical data enhanced understanding of the population characteristics of each centre and longitudinal analyses demonstrated changes over time.

\section{Methods}

These analyses relate to biochemical variables in the prevalent dialysis cohort in England, Wales and Northern Ireland in 2007. The cohort studied were patients prevalent on dialysis treatment on 31/12/07. HD and PD cohorts were analysed separately.

The biochemical variables analysed were phosphate, calcium, parathyroid hormone, bicarbonate and cholesterol. The method of data collection and validation by the UKRR has been described elsewhere [3]. For each quarter of 2007 the UKRR extracted biochemical data electronically from clinical information systems in UK dialysis centres. The UKRR does not collect data regarding different assay methods mainly because a single dialysis centre may process samples in several different laboratories. For centres providing adjusted calcium values, these data were analysed directly as it is these values on which clinical decisions within centres are based. For centres providing unadjusted calcium values, a formula in widespread use was used to calculate adjusted calcium [2]. The audit measure for adjusted calcium in the 4th edition of the Renal Association Clinical Practice Guidelines depends on a local reference range [1]. To enable comparative audit the UKRR has continued to use adjusted calcium between $2.2-2.6 \mathrm{mmol} / \mathrm{L}$ as an audit measure. There are also a variety of methods and reference ranges in use to measure parathyroid hormone. To enable some form of comparative audit the UKRR has chosen 2-4 times the median upper laboratory value as the audit measure. This equates to $16-32 \mathrm{pmol} / \mathrm{L}$ and is comparable to KDOQI $(15-31 \mathrm{pmol} / \mathrm{L})[2,4,5]$. The measure used for serum bicarbonate in the PD cohort was $25-29 \mathrm{mmol} / \mathrm{L}$ (the same as previous years) as the new audit measure specifies that serum bicarbonate should be maintained in the 'normal range'. A summary of the current Renal Association audit measures and conversion factors to SI units are given in table 10.1.

Quarterly values were extracted from the database for the last two quarters of 2007 for calcium, bicarbonate and phosphate, the last three quarters for iPTH and the entire year for cholesterol. Patients who did not have these data were excluded from the analyses. The completeness of data were analysed at centre and country level. All patients were included in analyses but centres with less than $50 \%$ completeness were excluded from plots showing centre performance. Data were also excluded from plots when there were less than 20 patients with data at centre level. These data were analysed to calculate summary statistics (maximum, minimum, mean and median values in addition to standard deviation and quartile ranges). Where applicable, the percentage achieving the Renal Association or other surrogate clinical performance measure was also calculated. The number preceding the centre name in each figure indicates the percentage of missing data for that centre. Funnel plot analysis was used to identify 'outlying units' [6]. The percentage achieving each standard was plotted against centre size along with the upper and lower 95\% and $99.9 \%$ limits. Centres can be identified on these plots by cross-referencing the ' $n$ ' value with the proportion of patients achieving the audit measure in the relevant table. Longitudinal analyses were performed for some data to calculate overall changes in achievement of a performance measure annually from 2000 to 2007. All data were unadjusted for case-mix.

\section{Results}

\section{Mineral and bone parameters \\ Phosphate}

The 4th edition of the Renal Association Clinical Practice Guidelines states:

Table 10.1. Summary of clinical audit measures and conversion factors from SI units

\begin{tabular}{lcc}
\hline Biochemical variable & Clinical audit measure & Conversion factor from SI units \\
\hline Phosphate & $1.1-1.8 \mathrm{mmol} / \mathrm{L}$ & $\mathrm{mg} / \mathrm{dl}=\mathrm{mmol} / \mathrm{L} \times 3.1$ \\
Calcium & Normal range $/ \mathrm{dl}=\mathrm{mmol} / \mathrm{L} \times 4$ & $\mathrm{ng} / \mathrm{L}=\mathrm{pmol} / \mathrm{L} \times 9.5$ \\
& (ideally $<2.5 \mathrm{mmol} / \mathrm{L})$ & $\mathrm{mg} / \mathrm{dl}=\mathrm{mmol} / \mathrm{L} \times 6.1$ \\
Parathyroid hormone & 2-4 times upper limit of normal & $\mathrm{mg} / \mathrm{dl}=\mathrm{mmol} / \mathrm{L} \times 38.6$ \\
Bicarbonate & HD patients: $20-26 \mathrm{mmol} / \mathrm{L}$ & PD patients: normal range \\
Cholesterol & No audit measure & \\
\hline
\end{tabular}


'Serum phosphate in dialysis patients (measured before a "short gap" dialysis session in HD patients) should be maintained between 1.1 and $1.8 \mathrm{mmol} / \mathrm{L}$.' (Module 2: Complications) [1]

The data for serum phosphate were $90 \%$ complete for HD patients and 95\% complete for PD patients overall although there was considerable variation between centres. Data from HD patients in Coventry and London West and PD patients in London West were not included as there was a problem with data extraction (tables 10.2 and 10.4).

The individual centres' means and standard deviations are shown in tables 10.2 and 10.4.

There was between centre variation in the proportion of patients below, within and above the range specified by the clinical performance measure (figures
10.1-10.12). Fifty three percent (CI 53-54\%) of HD patients and 64\% (CI 62-66\%) of PD patients achieved a phosphate between $1.1-1.8 \mathrm{mmol} / \mathrm{L}$ (tables 10.3 and 10.5). The proportion of HD patients with hyperphosphataemia was $31 \%$ (CI $31-32 \%$ ) compared to $33 \%$ in 2006 and the proportion with hypophosphataemia was $15 \%$ (CI $15-16 \%$ ) compared to $13 \%$ in 2006 (table 10.3 and figure 10.13). The proportion of PD patients with hyperphosphataemia was $26 \%$ (CI $24-27 \%$ ) compared to $25 \%$ in 2006 and the proportion with hypophosphataemia was $10 \%$ (CI 9-11\%) compared to $12 \%$ in 2006 (table 10.5 and figure 10.13).

\section{Adjusted Calcium}

The 4th edition of the Renal Association Clinical Practice Guidelines states:

Table 10.2. Summary statistics for phosphate in all haemodialysis patients in 2007

\begin{tabular}{|c|c|c|c|c|c|c|c|}
\hline Centre & $\begin{array}{c}\% \\
\text { completeness }\end{array}$ & $\begin{array}{c}\text { Number of } \\
\text { patients } \\
\text { with data }\end{array}$ & Mean & $\mathrm{SD}$ & Median & $\begin{array}{c}\text { Lower } \\
\text { quartile }\end{array}$ & $\begin{array}{c}\text { Upper } \\
\text { quartile }\end{array}$ \\
\hline B Heart & 93.6 & 334 & 1.71 & 0.51 & 1.66 & 1.34 & 2.02 \\
\hline $\mathrm{B} \mathrm{QEH}$ & 95.7 & 662 & 1.63 & 0.49 & 1.59 & 1.31 & 1.89 \\
\hline Bangor & 96.7 & 58 & 1.64 & 0.45 & 1.62 & 1.24 & 2.03 \\
\hline Bradfd & 99.4 & 158 & 1.62 & 0.54 & 1.52 & 1.25 & 1.95 \\
\hline Brightn & 99.7 & 297 & 1.53 & 0.50 & 1.51 & 1.18 & 1.81 \\
\hline Bristol & 100.0 & 428 & 1.72 & 0.52 & 1.68 & 1.38 & 2.00 \\
\hline Camb & 56.0 & 186 & 1.58 & 0.57 & 1.54 & 1.17 & 1.83 \\
\hline Cardff & 97.1 & 442 & 1.63 & 0.51 & 1.58 & 1.28 & 1.96 \\
\hline Carlis & 95.1 & 77 & 1.82 & 0.49 & 1.78 & 1.49 & 2.07 \\
\hline Derby & 100.0 & 183 & 1.63 & 0.56 & 1.58 & 1.25 & 1.93 \\
\hline Derry & 100.0 & 41 & 1.73 & 0.66 & 1.64 & 1.23 & 2.01 \\
\hline Donc & 100.0 & 54 & 1.68 & 0.63 & 1.60 & 1.20 & 2.10 \\
\hline Dorset & 100.0 & 139 & 1.63 & 0.51 & 1.57 & 1.28 & 2.00 \\
\hline Dudley & 86.4 & 95 & 1.61 & 0.57 & 1.58 & 1.28 & 1.93 \\
\hline Exeter & 99.2 & 260 & 1.64 & 0.53 & 1.56 & 1.27 & 1.90 \\
\hline Glouc & 99.4 & 161 & 1.62 & 0.48 & 1.56 & 1.28 & 1.95 \\
\hline Hull & 97.7 & 291 & 1.51 & 0.58 & 1.49 & 1.12 & 1.84 \\
\hline Ipswi & 100.0 & 90 & 1.64 & 0.48 & 1.62 & 1.27 & 1.91 \\
\hline L Barts & 99.8 & 550 & 1.63 & 0.53 & 1.61 & 1.29 & 1.91 \\
\hline L Guys & 96.6 & 429 & 1.48 & 0.50 & 1.50 & 1.10 & 1.80 \\
\hline L Kings & 100.0 & 309 & 1.51 & 0.46 & 1.45 & 1.16 & 1.81 \\
\hline
\end{tabular}


Table 10.2. Continued

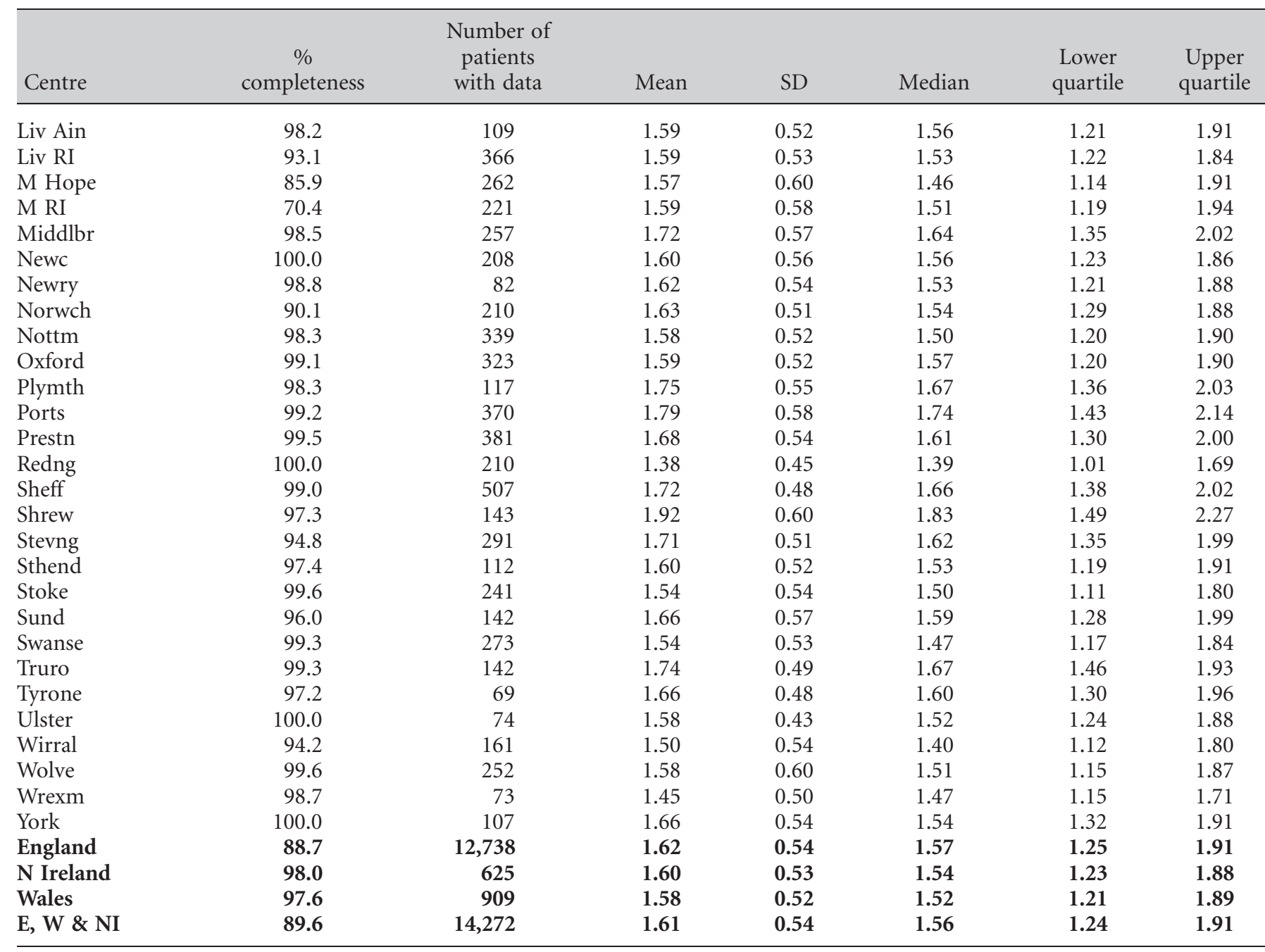

Blank cells denote centres excluded from analyses due to low patient numbers or poor data completeness

Table 10.3. Percentage of haemodialysis patients within, below and above the range for phosphate $(1.1-1.8 \mathrm{mmol} / \mathrm{L})$ in 2007

\begin{tabular}{|c|c|c|c|c|c|c|c|c|c|c|}
\hline Centre & $\mathrm{N}$ & $\begin{array}{c}\% \text { phos } \\
1.1-1.8 \\
\mathrm{mmol} / \mathrm{L}\end{array}$ & $\begin{array}{l}\text { Lower } \\
95 \% \text { CI }\end{array}$ & $\begin{array}{c}\text { Upper } \\
95 \% \text { CI }\end{array}$ & $\begin{array}{c}\% \text { phos } \\
<1.1 \\
\text { mmol/L }\end{array}$ & $\begin{array}{l}\text { Lower } \\
95 \% \text { CI }\end{array}$ & $\begin{array}{c}\text { Upper } \\
95 \% \text { CI }\end{array}$ & $\begin{array}{c}\% \text { phos } \\
>1.8 \\
\mathrm{mmol} / \mathrm{L}\end{array}$ & $\begin{array}{l}\text { Lower } \\
95 \% \text { CI }\end{array}$ & $\begin{array}{l}\text { Upper } \\
95 \% \text { CI }\end{array}$ \\
\hline B Heart & 334 & 54.5 & 49.1 & 59.8 & 9.0 & 6.4 & 12.6 & 36.5 & 31.5 & 41.8 \\
\hline B QEH & 662 & 60.9 & 57.1 & 64.5 & 10.0 & 7.9 & 12.5 & 29.2 & 25.8 & 32.7 \\
\hline Bangor & 58 & 50.0 & 37.4 & 62.6 & 8.6 & 3.6 & 19.1 & 41.4 & 29.5 & 54.3 \\
\hline Bradfd & 158 & 51.3 & 43.5 & 59.0 & 13.9 & 9.4 & 20.2 & 34.8 & 27.8 & 42.6 \\
\hline Brightn & 297 & 54.2 & 48.5 & 59.8 & 20.2 & 16.0 & 25.2 & 25.6 & 21.0 & 30.9 \\
\hline Bristol & 428 & 51.4 & 46.7 & 56.1 & 10.1 & 7.5 & 13.3 & 38.6 & 34.1 & 43.3 \\
\hline Camb & 186 & 54.3 & 47.1 & 61.3 & 18.3 & 13.4 & 24.5 & 27.4 & 21.5 & 34.3 \\
\hline Cardff & 442 & 52.5 & 47.8 & 57.1 & 14.7 & 11.7 & 18.3 & 32.8 & 28.6 & 37.3 \\
\hline Carlis & 77 & 46.8 & 36.0 & 57.9 & 6.5 & 2.7 & 14.7 & 46.8 & 36.0 & 57.9 \\
\hline
\end{tabular}


Table 10.3. Continued

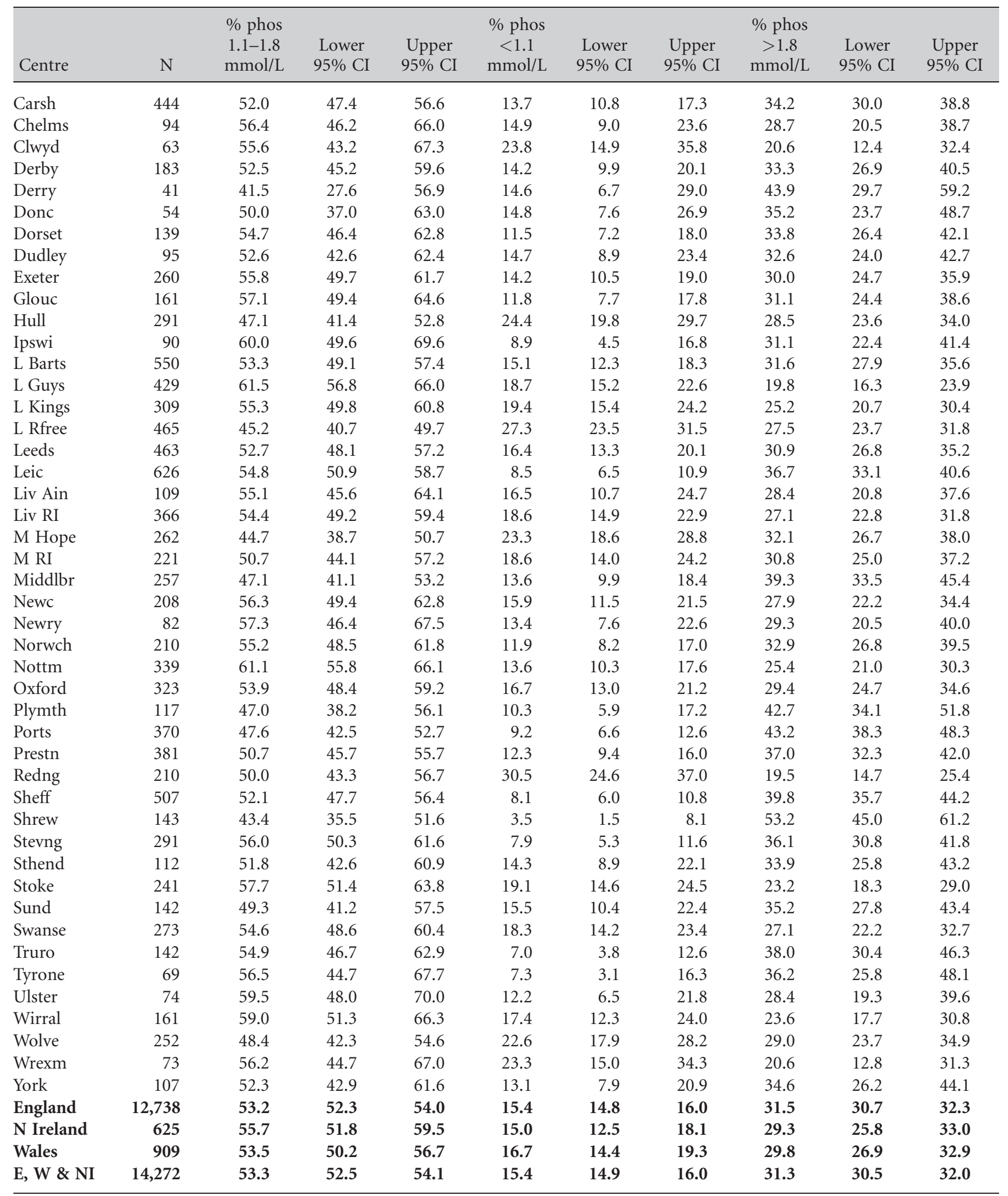


Table 10.4. Summary statistics for phosphate in peritoneal dialysis patients in 2007

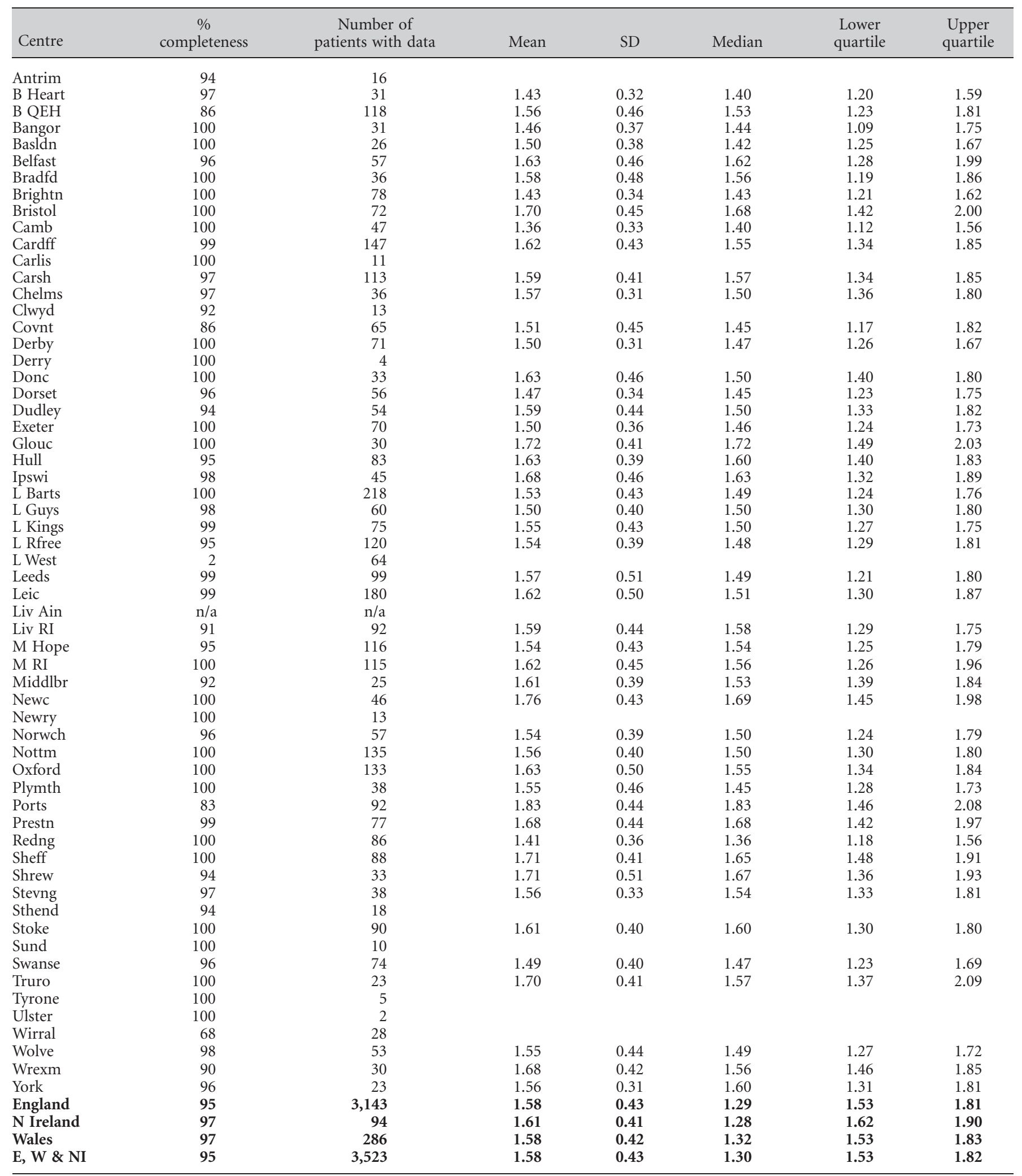

Blank cells denote centres excluded from analyses due to low patient numbers or poor data completeness n/a not applicable 


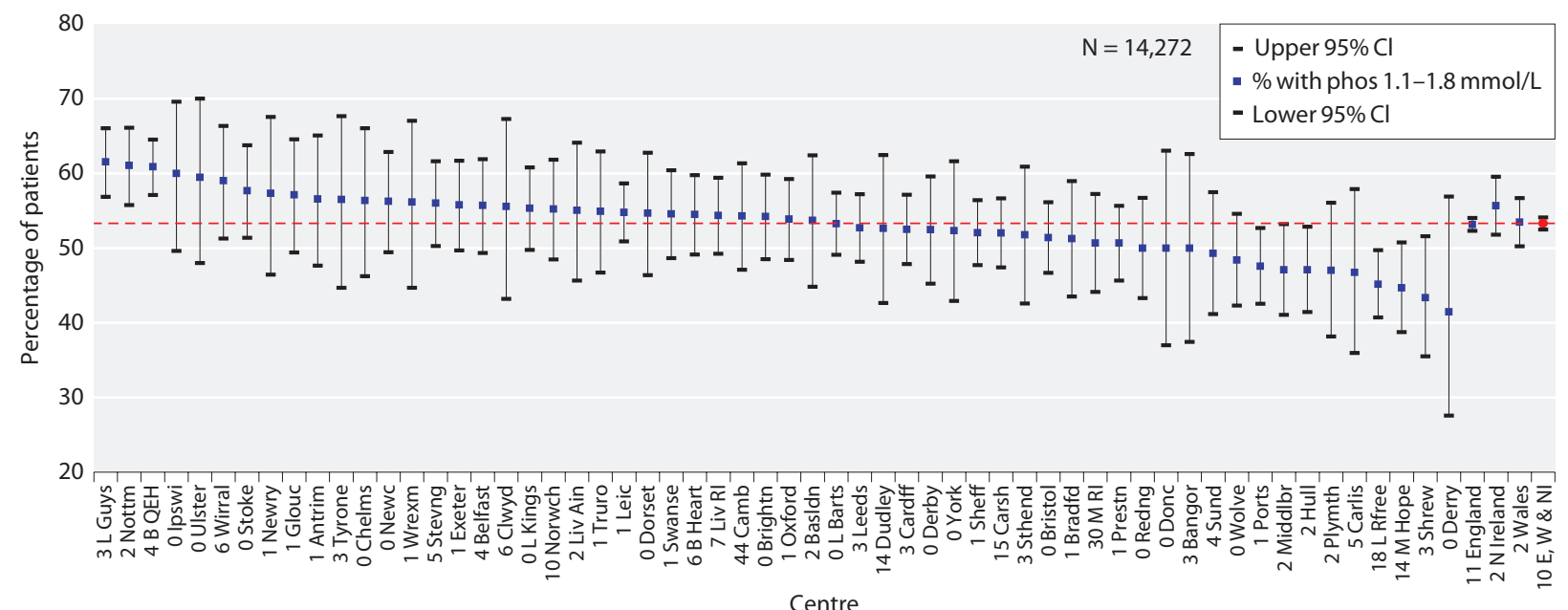

Fig. 10.1. Percentage of haemodialysis patients with phosphate $1.1-1.8 \mathrm{mmol} / \mathrm{L}$ by centre in 2007

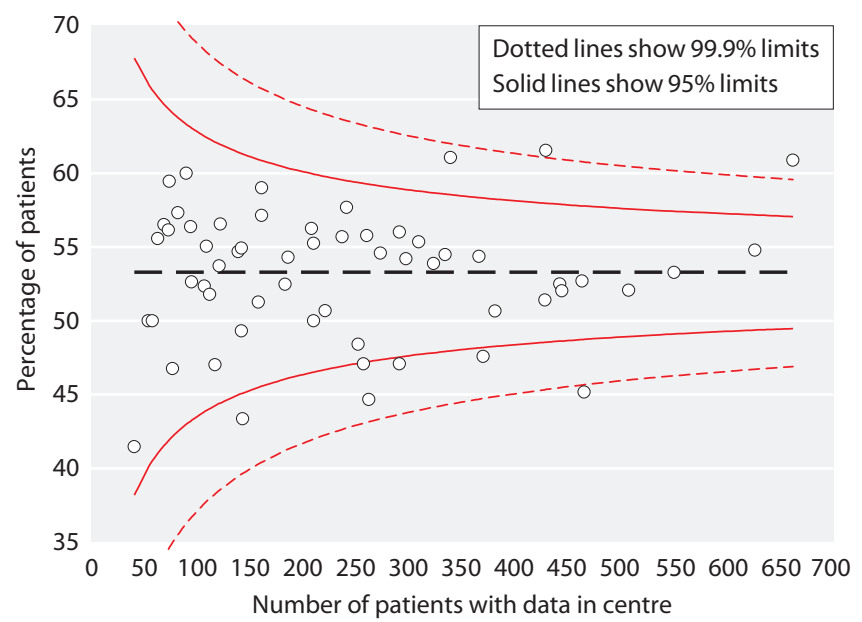

Fig. 10.2. Funnel plot of percentage of haemodialysis patients with phosphate $1.1-1.8 \mathrm{mmol} / \mathrm{L}$ by centre in 2007

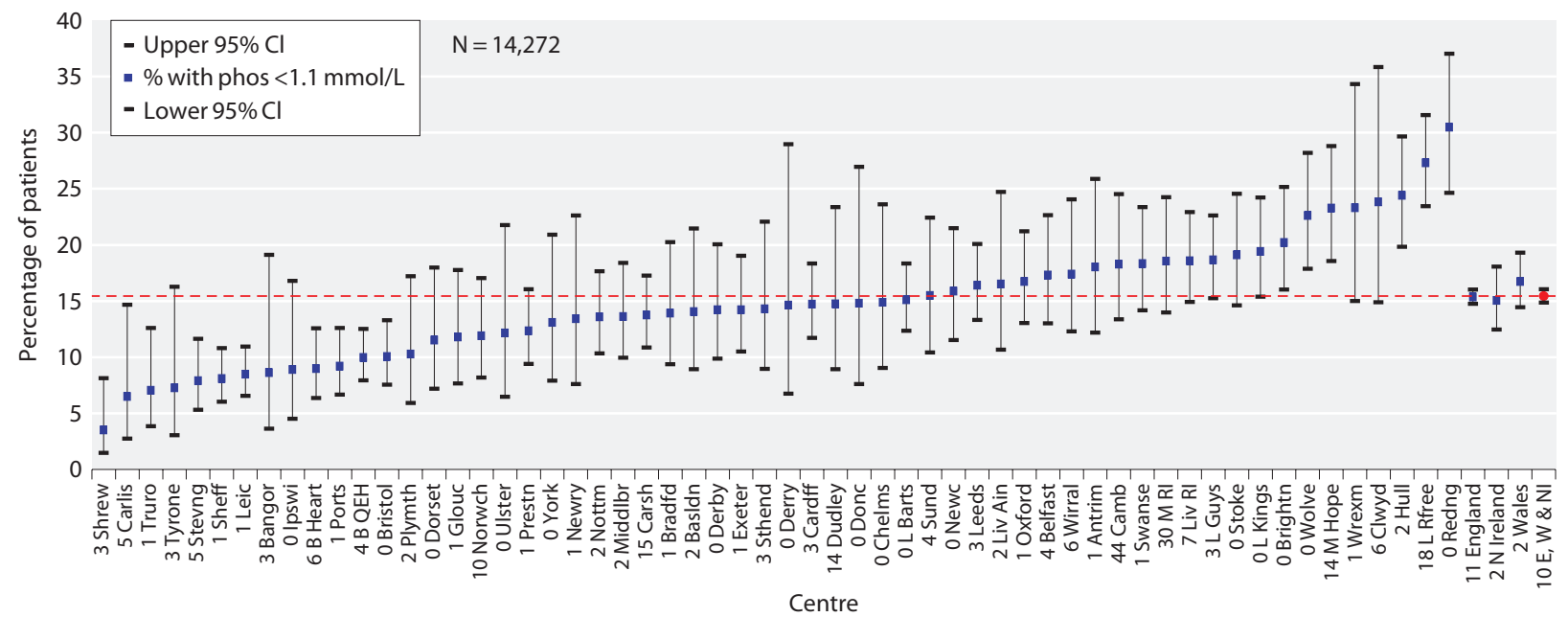

Fig. 10.3. Percentage of haemodialysis patients with phosphate $<1.1 \mathrm{mmol} / \mathrm{L}$ by centre in 2007 


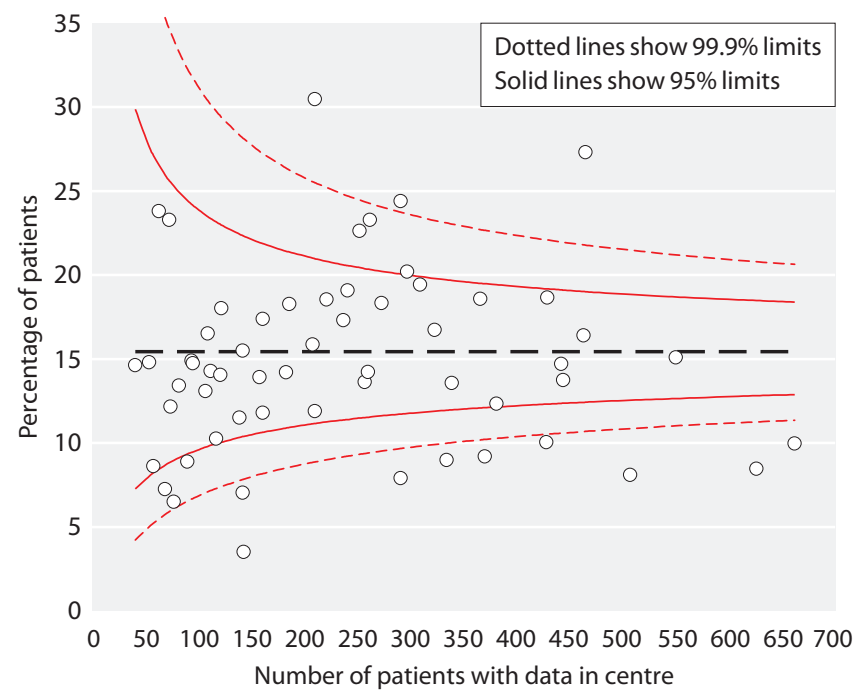

Fig. 10.4. Funnel plot of percentage of haemodialysis patients with phosphate $<1.1 \mathrm{mmol} / \mathrm{L}$ by centre in 2007

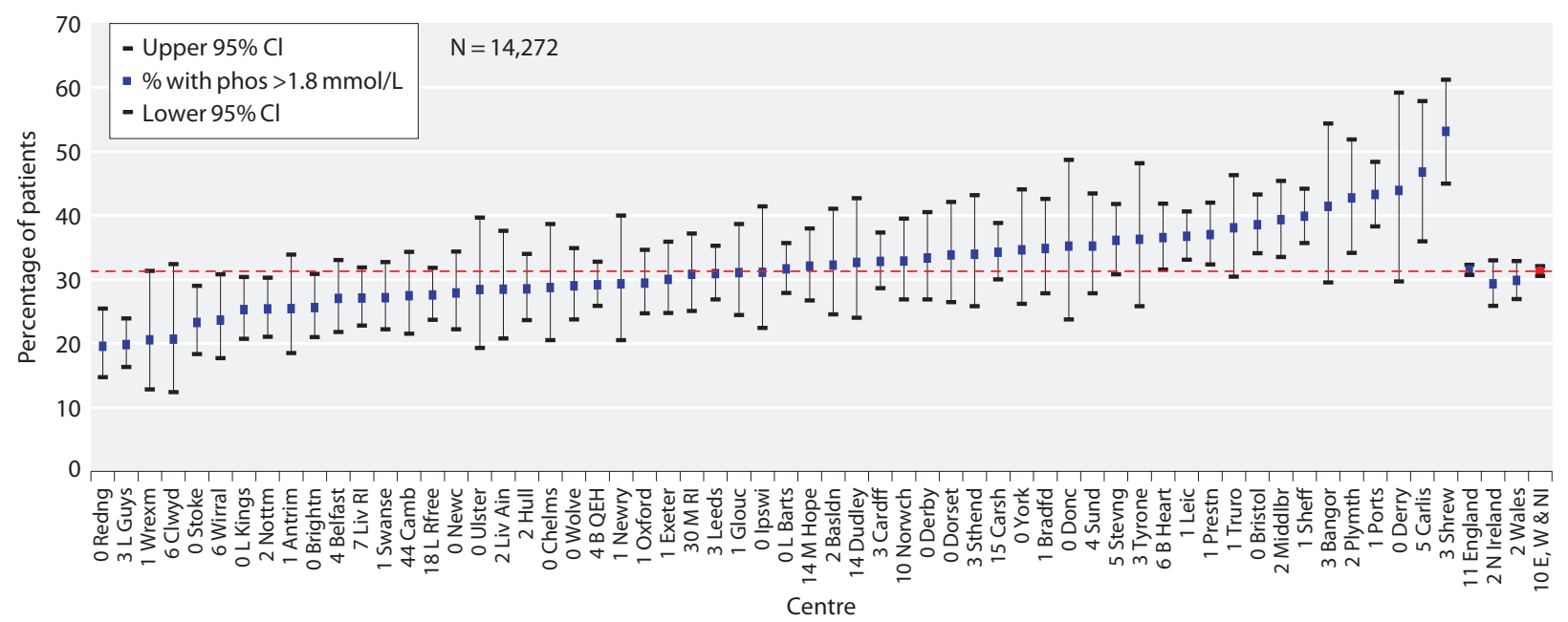

Fig. 10.5. Percentage of haemodialysis patients with phosphate $>1.8 \mathrm{mmol} / \mathrm{L}$ by centre in 2007

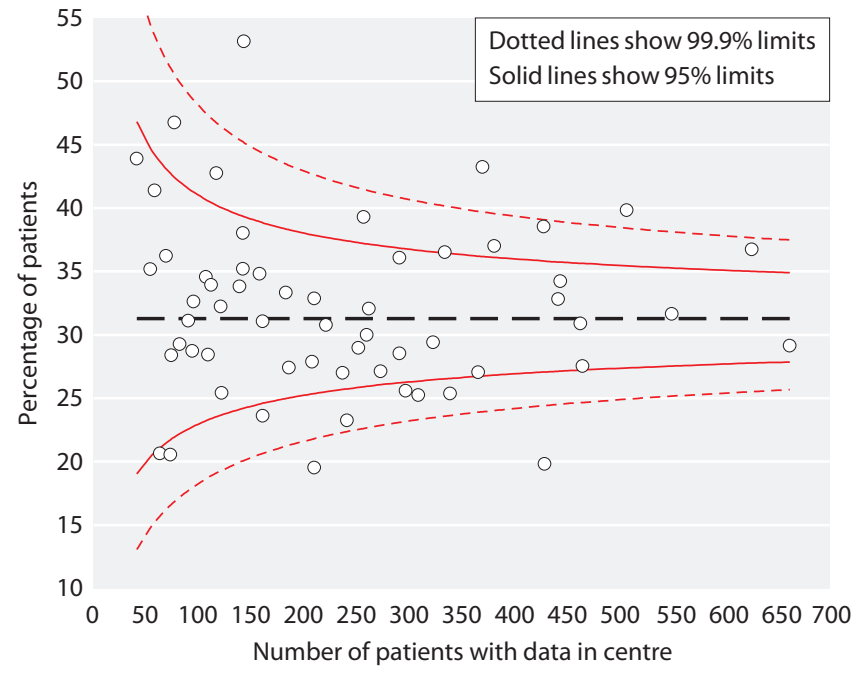

Fig. 10.6. Funnel plot of percentage of haemodialysis patients with phosphate $>1.8 \mathrm{mmol} / \mathrm{L}$ by centre in 2007 


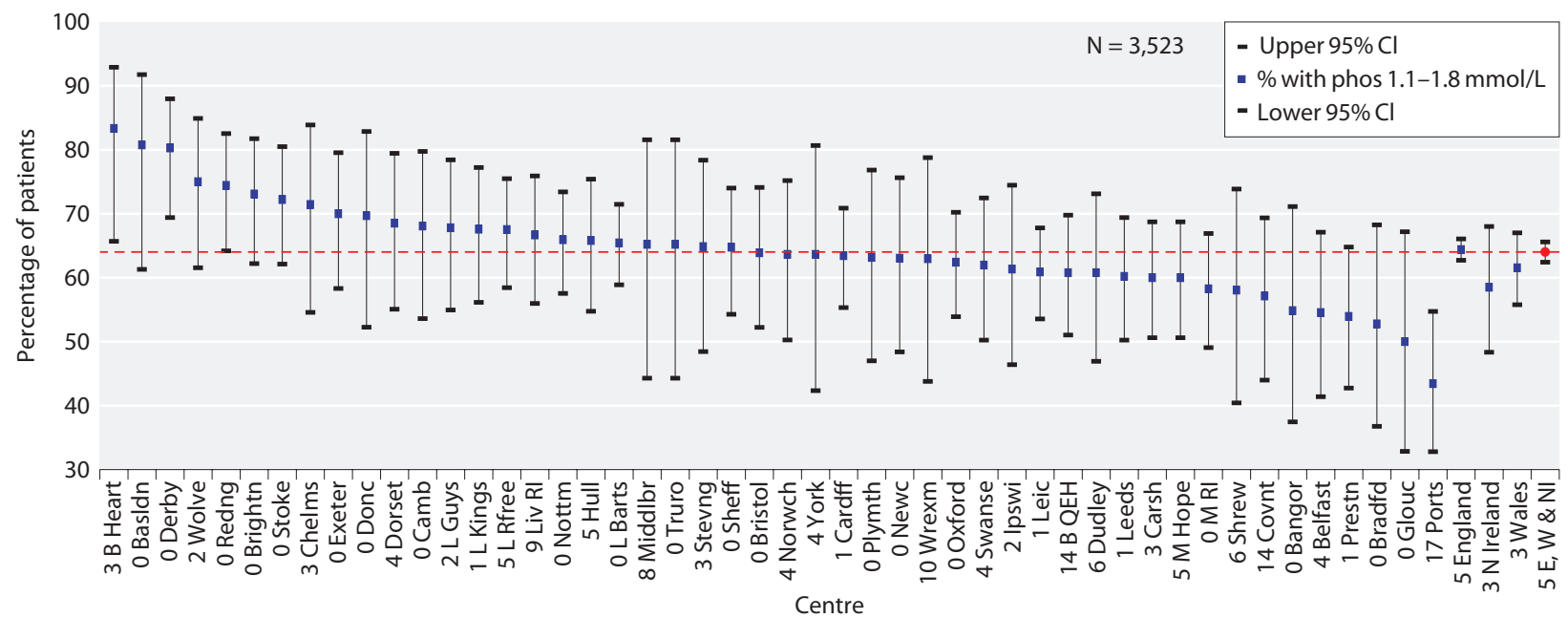

Fig. 10.7. Percentage of peritoneal dialysis patients with phosphate $1.1-1.8 \mathrm{mmol} / \mathrm{L}$ by centre in 2007

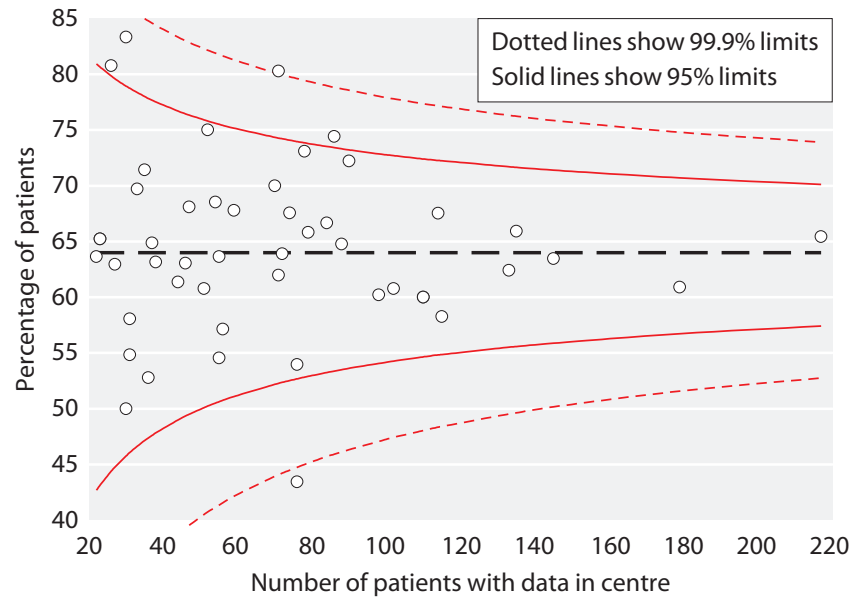

Fig. 10.8. Funnel plot of percentage of peritoneal dialysis patients with phosphate $1.1-1.8 \mathrm{mmol} / \mathrm{L}$ by centre in 2007

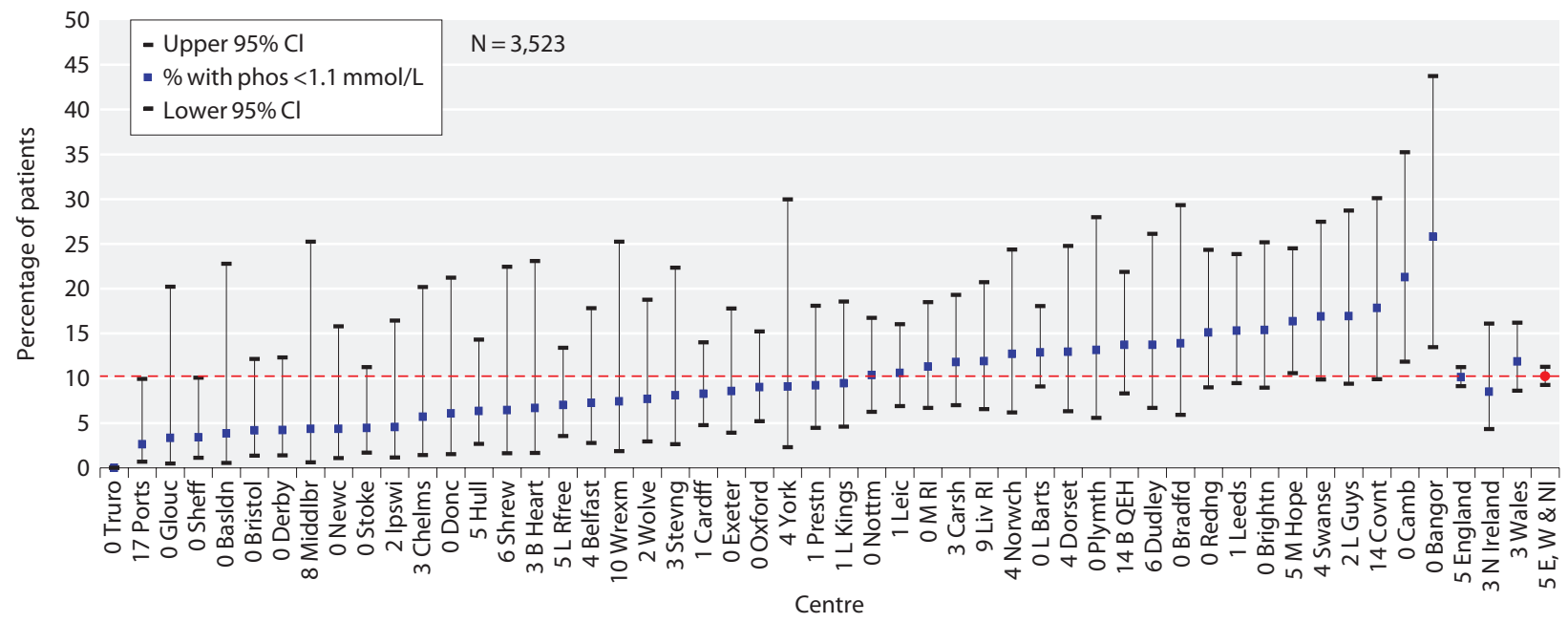

Fig. 10.9. Percentage of peritoneal dialysis patients with phosphate $<1.1 \mathrm{mmol} / \mathrm{L}$ by centre in 2007 


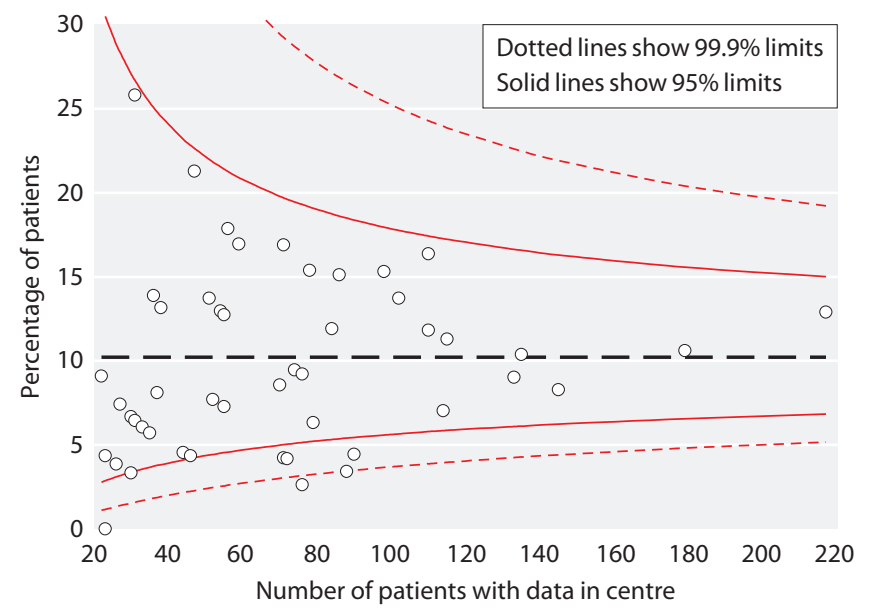

Fig. 10.10. Funnel plot of percentage of peritoneal dialysis patients with phosphate $<1.1 \mathrm{mmol} / \mathrm{L}$ by centre in 2007

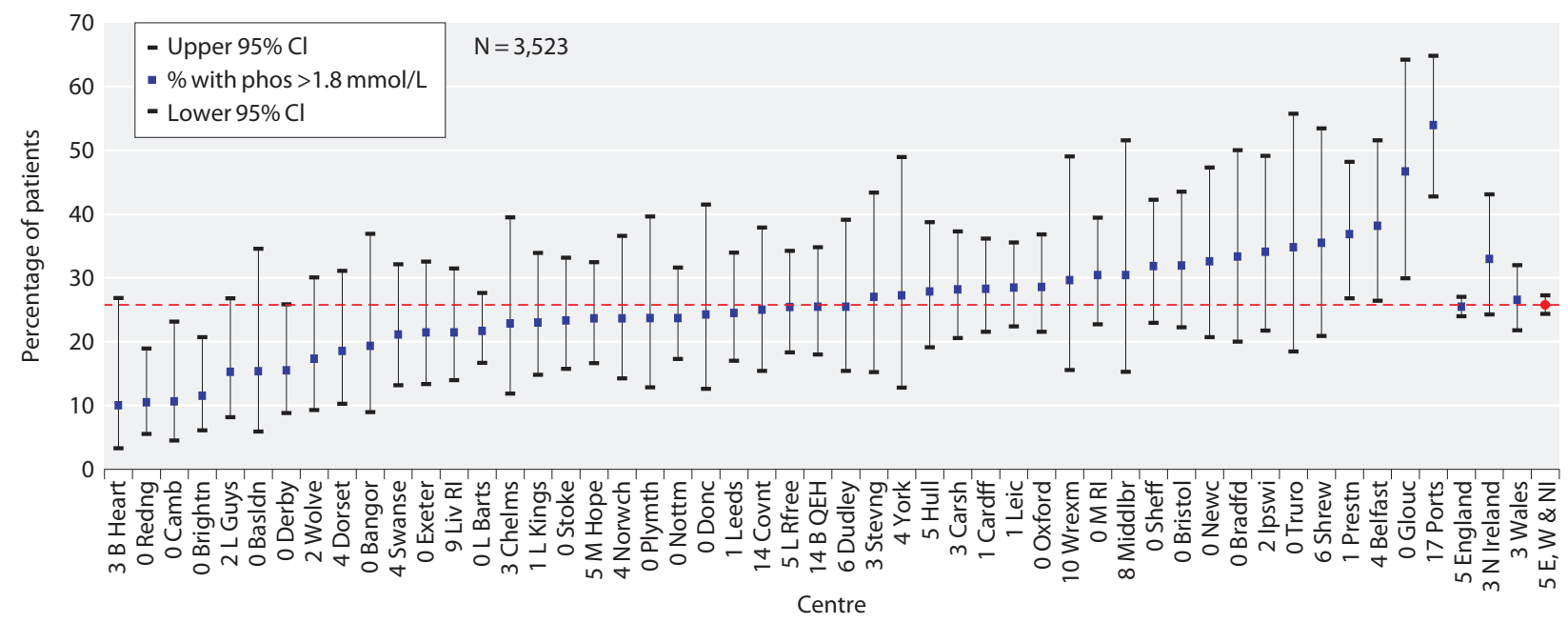

Fig. 10.11. Percentage of peritoneal dialysis patients with phosphate $>1.8 \mathrm{mmol} / \mathrm{L}$ by centre in 2007

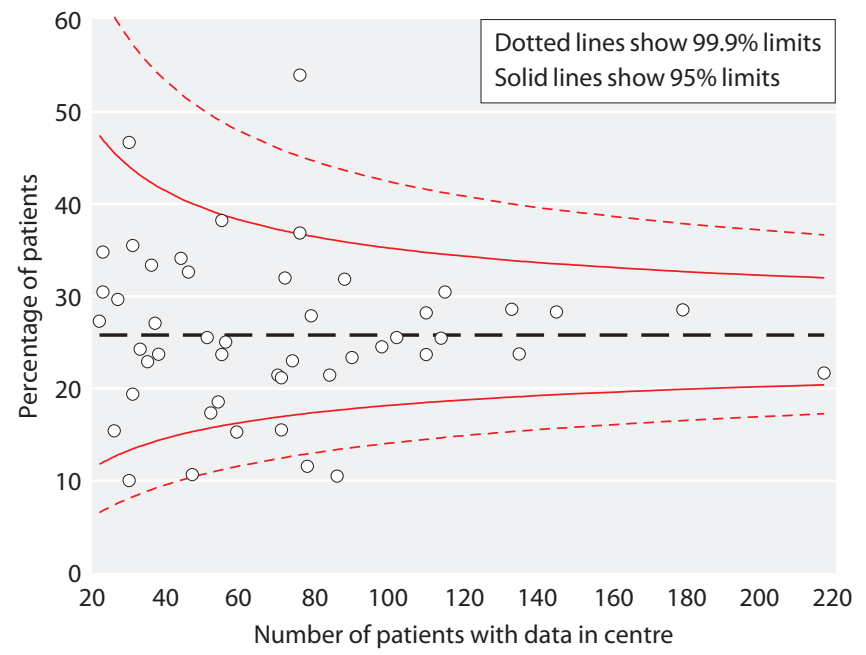

Fig. 10.12. Funnel plot of percentage of peritoneal dialysis patients with phosphate above the range $(>1.8 \mathrm{mmol} / \mathrm{L})$ by centre in 2007 
Table 10.5. Percentage of peritoneal dialysis patients within, below and above the range for phosphate (1.1-1.8 mmol/L) in 2007

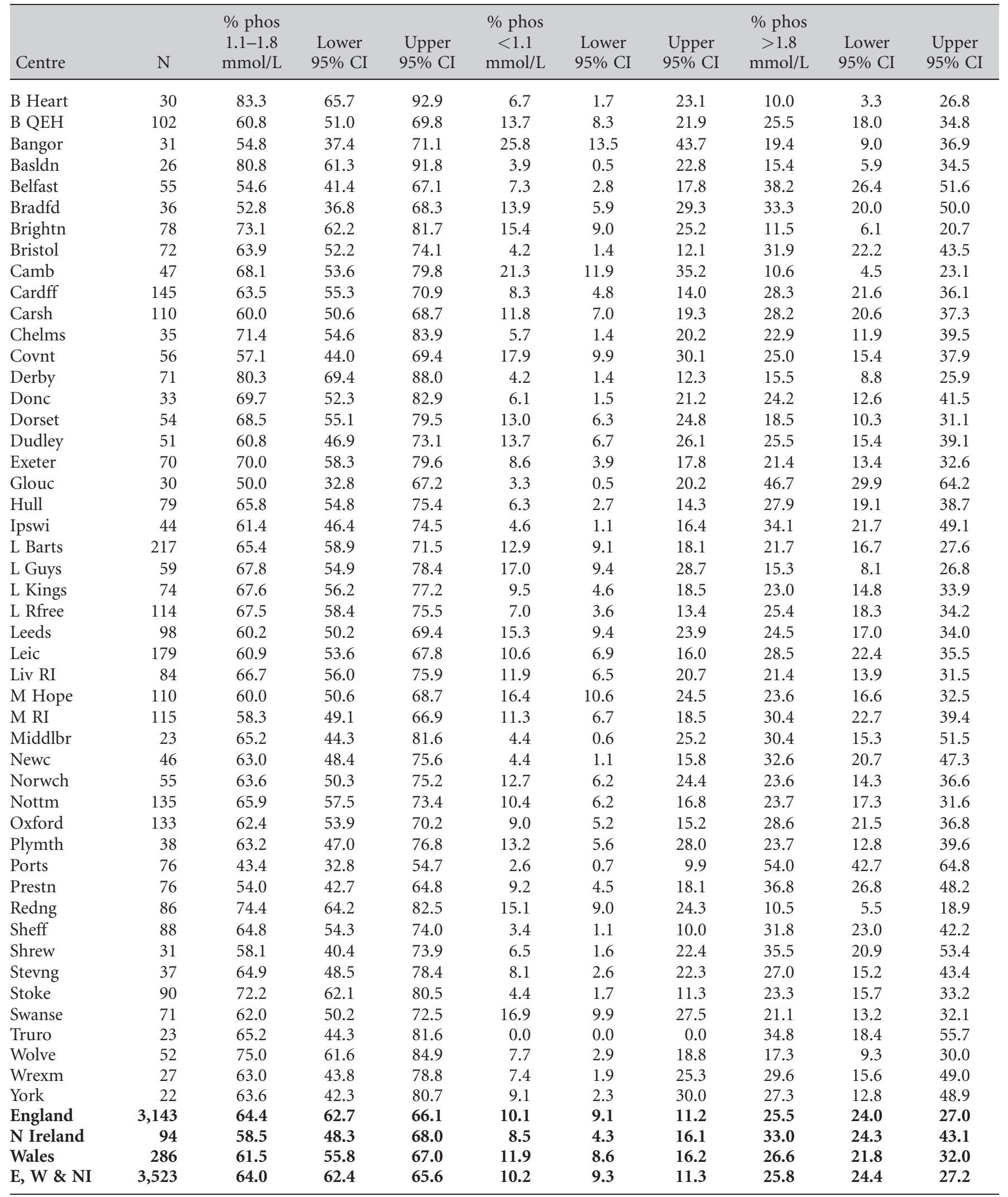




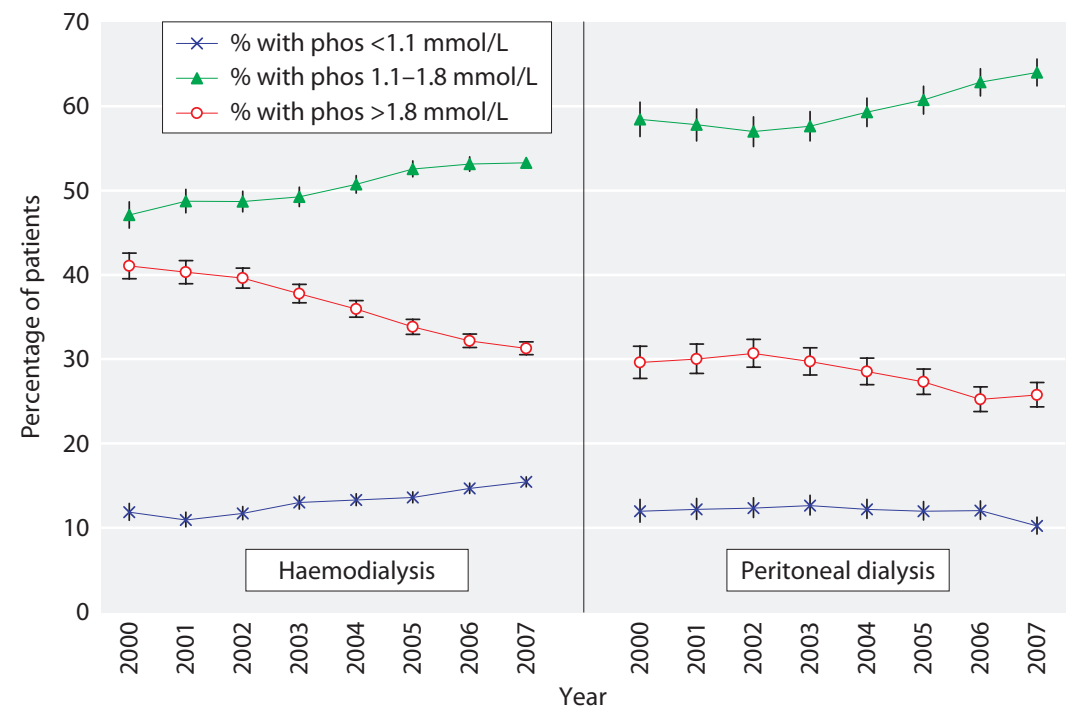

Fig. 10.13. Longitudinal change in percentage of patients with phosphate $<1.1 \mathrm{mmol} / \mathrm{L}, 1.1-1.8 \mathrm{mmol} / \mathrm{L}$ and $>1.8 \mathrm{mmol} / \mathrm{L}$ by dialysis modality 2000 2007
'Serum calcium, adjusted for albumin concentration should be maintained within the normal reference range for the laboratory used (measured before a "short gap" dialysis session in HD patients) and ideally kept below $2.5 \mathrm{mmol} / \mathrm{L}$.' (Module 2: Complications) [1]

The audit measure for calcium in the 4th edition of the Renal Association clinical practice guidelines does not specify a lower limit for calcium and advises that adjusted calcium should be ideally within the normal range. For this reason the UKRR has continued to use $2.2-2.6 \mathrm{mmol} / \mathrm{L}$ as an audit measure for 2007 data. The guideline does however recommend that adjusted calcium should be $<2.5 \mathrm{mmol} / \mathrm{L}$. The UKRR is considering using 2.2-2.5 $\mathrm{mmol} / \mathrm{L}$ as the audit measure for adjusted calcium in subsequent analyses. The data for adjusted calcium were 91\% complete for HD patients and 96\% complete for PD patients overall although there was between centre variation. Data from HD patients in London West were not included as there was a problem with data extraction (tables 10.6 and 10.8). Seventy three percent (CI 72$73 \%$ ) of HD patients and 78\% (CI 77-80\%) of PD patients achieved adjusted calcium between $2.2-2.6 \mathrm{mmol} / \mathrm{L}$ (tables 10.7 and 10.9). The proportion of HD patients with hypercalcaemia was 7\% (CI 7-8\%) compared to 9\% in 2006 and the proportion with hypocalcaemia was $20 \%$ (CI 20-21\%) compared to $17 \%$ in 2006 (table 10.7). The proportion of PD patients with hypercalcaemia was 9\% (CI 8-10\%) compared to $25 \%$ in 2006 and the proportion with hypocalcaemia was $13 \%$ (CI $12-14 \%$ ) compared to $10 \%$ in 2006 (table 10.9 and figure 10.26).

As was the case for phosphate, there was between centre variation in unadjusted analyses for the proportion of patients below, within and above the range specified by the clinical performance measure (figures 10.14-10.25). There was greater variation in the proportion of patients within range for adjusted calcium compared to phosphate most notably for HD patients. The funnel plot shows a greater number of centres outlying the $3 \mathrm{SD}$ limit i.e. there is over dispersion.

Table 10.6. Summary statistics for adjusted calcium in haemodialysis patients in 2007

\begin{tabular}{|c|c|c|c|c|c|c|c|}
\hline Centre & $\begin{array}{c}\% \\
\text { completeness }\end{array}$ & $\begin{array}{c}\text { Number of } \\
\text { patients } \\
\text { with data }\end{array}$ & Mean & $\mathrm{SD}$ & Median & $\begin{array}{c}\text { Lower } \\
\text { quartile }\end{array}$ & $\begin{array}{c}\text { Upper } \\
\text { quartile }\end{array}$ \\
\hline Antrim & 99 & 122 & 2.35 & 0.16 & 2.32 & 2.26 & 2.46 \\
\hline B Heart & 94 & 334 & 2.28 & 0.21 & 2.28 & 2.17 & 2.39 \\
\hline B QEH & 96 & 666 & 2.30 & 0.19 & 2.31 & 2.20 & 2.42 \\
\hline Bangor & 95 & 57 & 2.37 & 0.19 & 2.34 & 2.26 & 2.45 \\
\hline Basldn & 98 & 121 & 2.41 & 0.15 & 2.40 & 2.32 & 2.52 \\
\hline Belfast & 96 & 237 & 2.32 & 0.19 & 2.31 & 2.20 & 2.42 \\
\hline Bradfd & 99 & 158 & 2.42 & 0.16 & 2.44 & 2.34 & 2.50 \\
\hline Brightn & 71 & 211 & 2.29 & 0.19 & 2.31 & 2.17 & 2.42 \\
\hline
\end{tabular}


Table 10.6. Continued

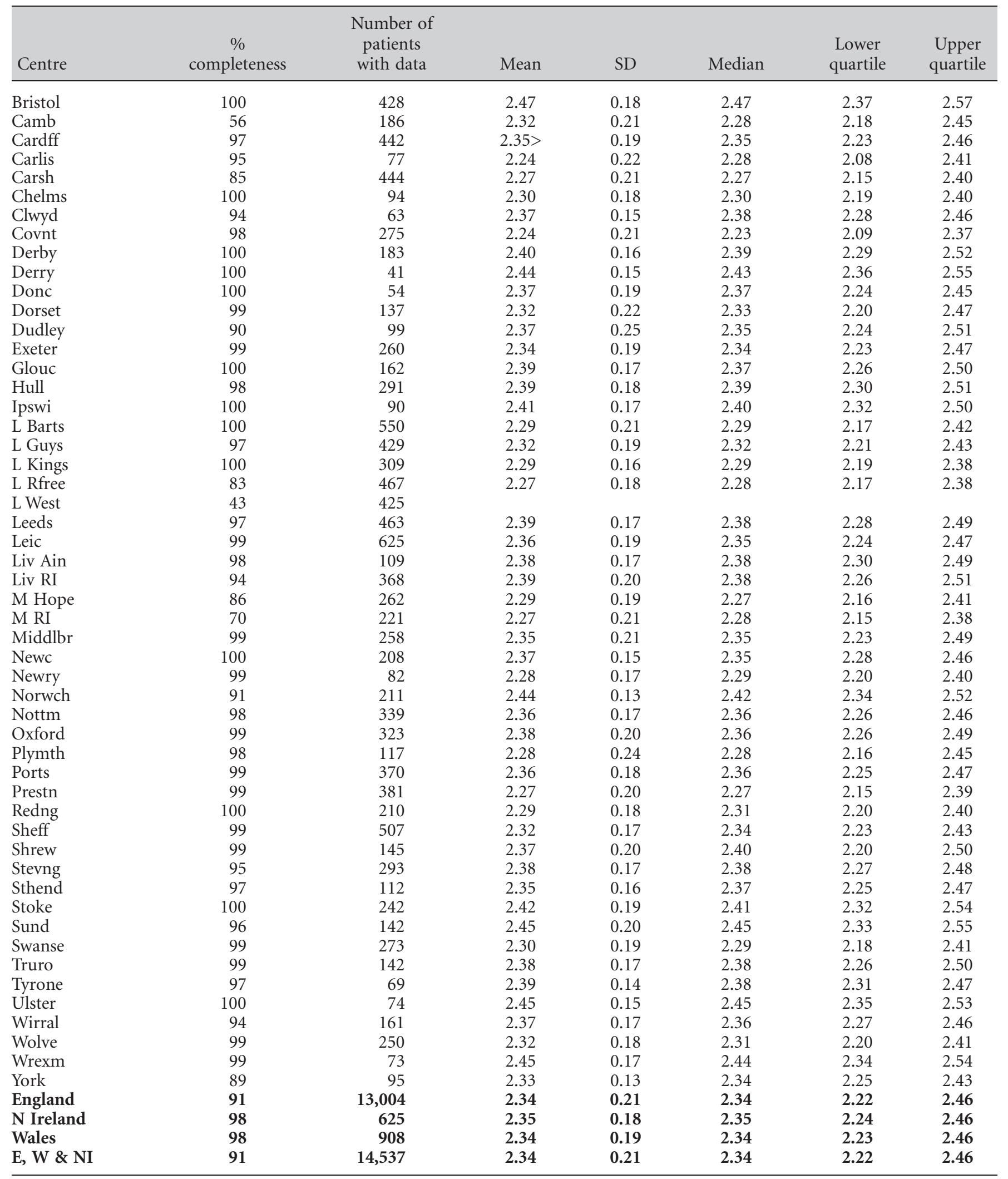

Blank cells denote centres excluded from analyses due to low patient numbers or poor data completeness 
Table 10.7. Percentage of haemodialysis patients within, below and above the range for adjusted calcium (2.2-2.6 mmol/L) in 2007

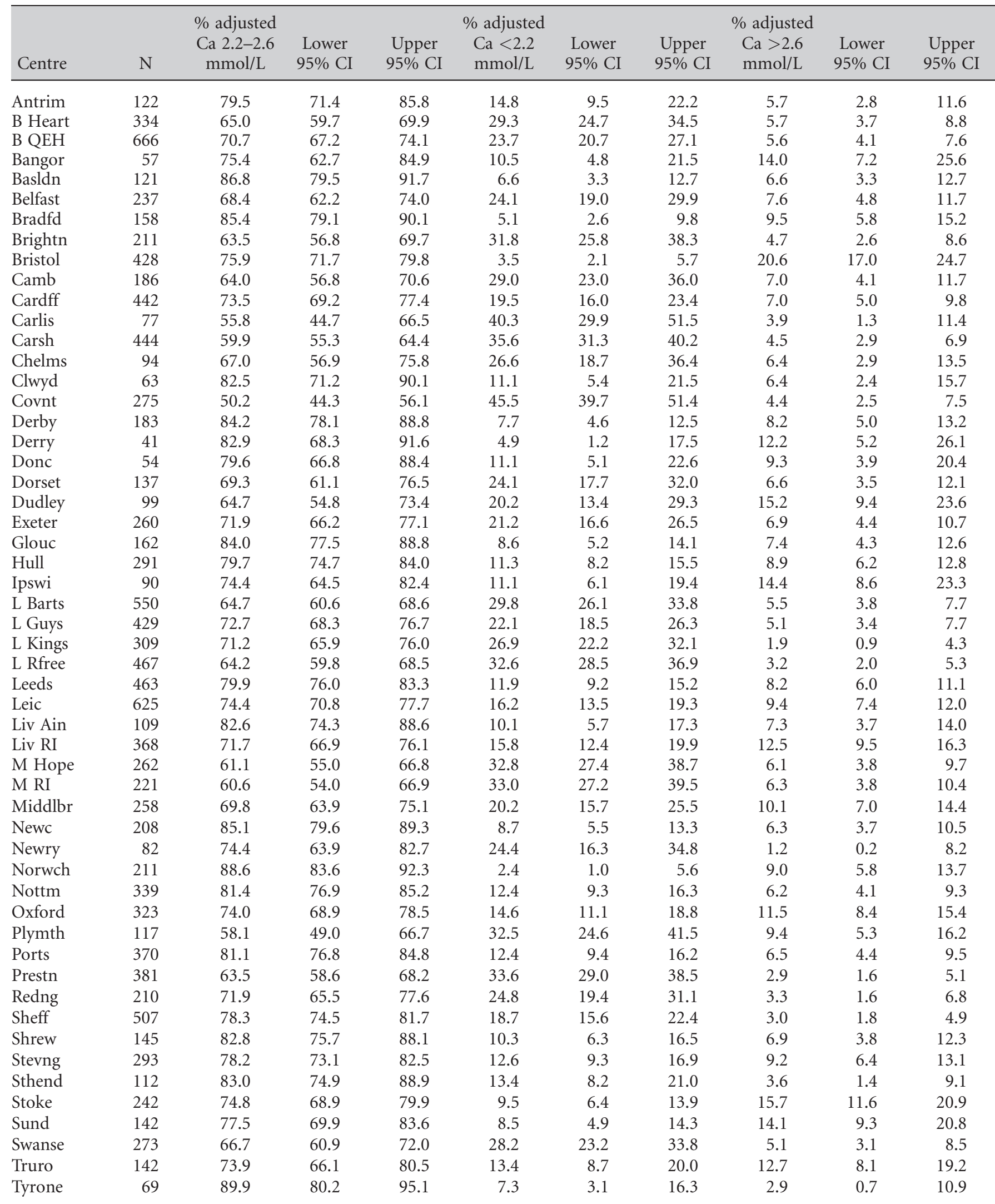


Table 10.7. Continued

\begin{tabular}{|c|c|c|c|c|c|c|c|c|c|c|}
\hline Centre & $\mathrm{N}$ & $\begin{array}{c}\% \text { adjusted } \\
\mathrm{Ca} 2.2-2.6 \\
\mathrm{mmol} / \mathrm{L}\end{array}$ & $\begin{array}{l}\text { Lower } \\
95 \% \text { CI }\end{array}$ & $\begin{array}{c}\text { Upper } \\
95 \% \text { CI }\end{array}$ & $\begin{array}{c}\% \text { adjusted } \\
\mathrm{Ca}<2.2 \\
\mathrm{mmol} / \mathrm{L}\end{array}$ & $\begin{array}{l}\text { Lower } \\
95 \% \text { CI }\end{array}$ & $\begin{array}{l}\text { Upper } \\
95 \% \text { CI }\end{array}$ & $\begin{array}{c}\% \text { adjusted } \\
\mathrm{Ca}>2.6 \\
\mathrm{mmol} / \mathrm{L}\end{array}$ & $\begin{array}{l}\text { Lower } \\
95 \% \text { CI }\end{array}$ & $\begin{array}{c}\text { Upper } \\
95 \% \text { CI }\end{array}$ \\
\hline Wirral & 161 & 80.8 & 73.9 & 86.1 & 13.0 & 8.7 & 19.2 & 6.2 & 3.4 & 11.2 \\
\hline Wolve & 250 & 71.2 & 65.3 & 76.5 & 23.2 & 18.4 & 28.8 & 5.6 & 3.3 & 9.2 \\
\hline Wrexm & 73 & 79.5 & 68.7 & 87.2 & 4.1 & 1.3 & 12.0 & 16.4 & 9.6 & 26.8 \\
\hline N Ireland & 625 & 76.3 & 72.8 & 79.5 & 16.8 & 14.1 & 19.9 & 6.9 & 5.1 & 9.2 \\
\hline Wales & 908 & 72.7 & 69.7 & 75.5 & 19.7 & 17.3 & 22.4 & 7.6 & 6.1 & 9.5 \\
\hline $\mathrm{E}, \mathrm{W} \& \mathrm{NI}$ & 14,537 & 72.5 & 71.7 & 73.2 & 20.2 & 19.6 & 20.9 & 7.3 & 6.9 & 7.8 \\
\hline
\end{tabular}

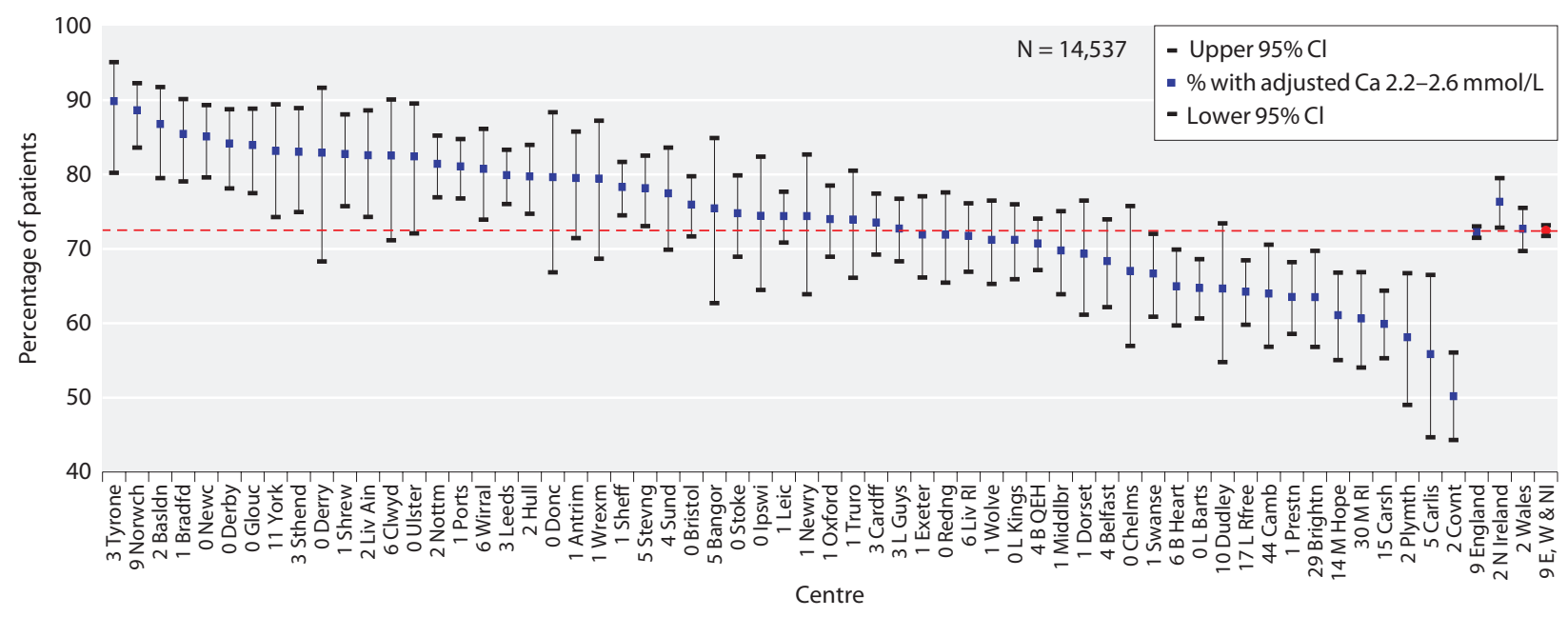

Fig. 10.14. Percentage of haemodialysis patients with adjusted calcium $2.2-2.6 \mathrm{mmol} / \mathrm{L}$ by centre in 2007

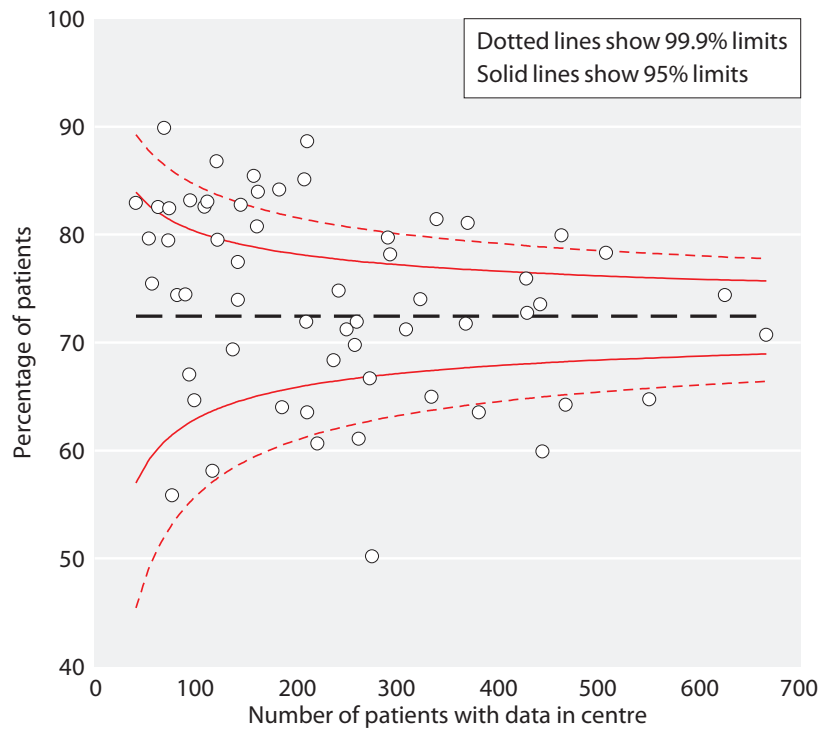

UK management of biochemical variables
Fig. 10.15. Funnel plot of percentage of haemodialysis patients with adjusted calcium $2.2-2.6 \mathrm{mmol} / \mathrm{L}$ by centre in 2007 


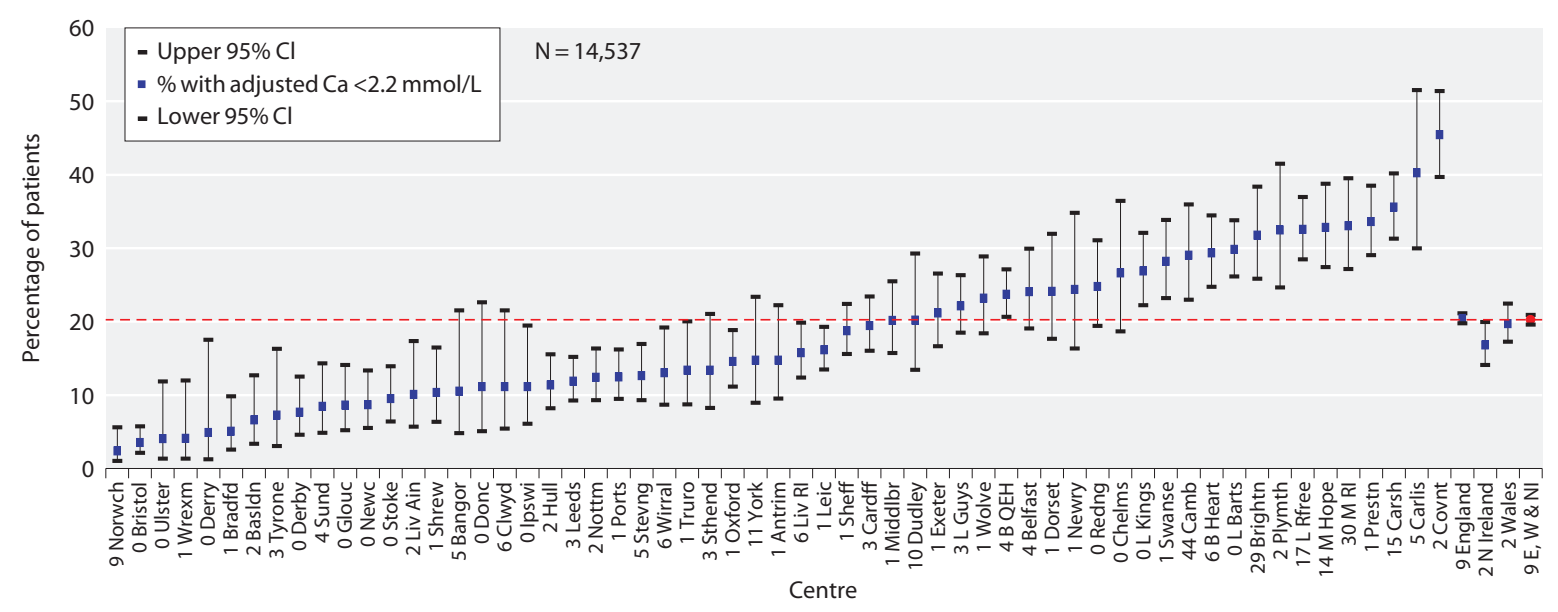

Fig. 10.16. Percentage of haemodialysis patients with adjusted calcium $<2.2 \mathrm{mmol} / \mathrm{L}$ by centre in 2007

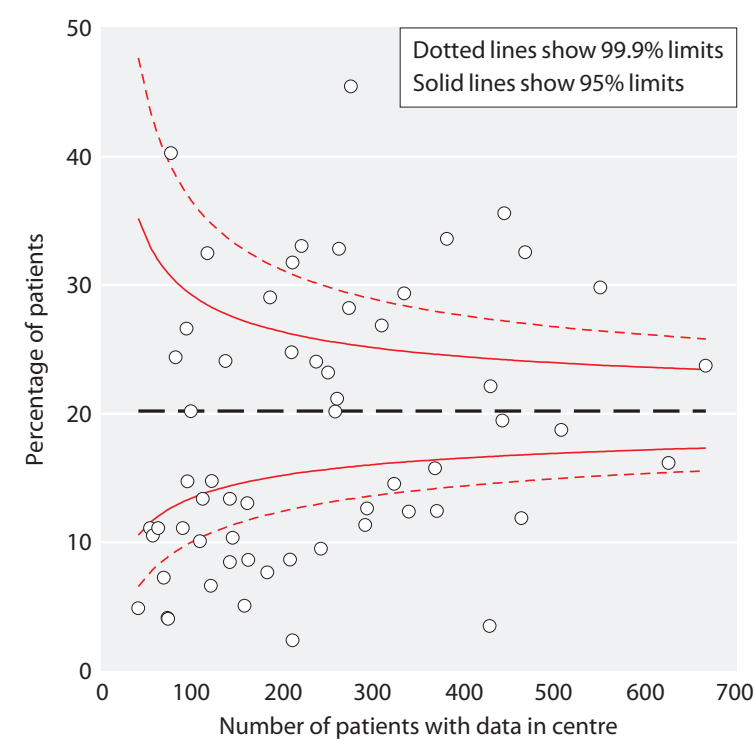

Fig. 10.17. Funnel plot of percentage of haemodialysis patients with adjusted calcium $<2.2 \mathrm{mmol} / \mathrm{L}$ by centre in 2007

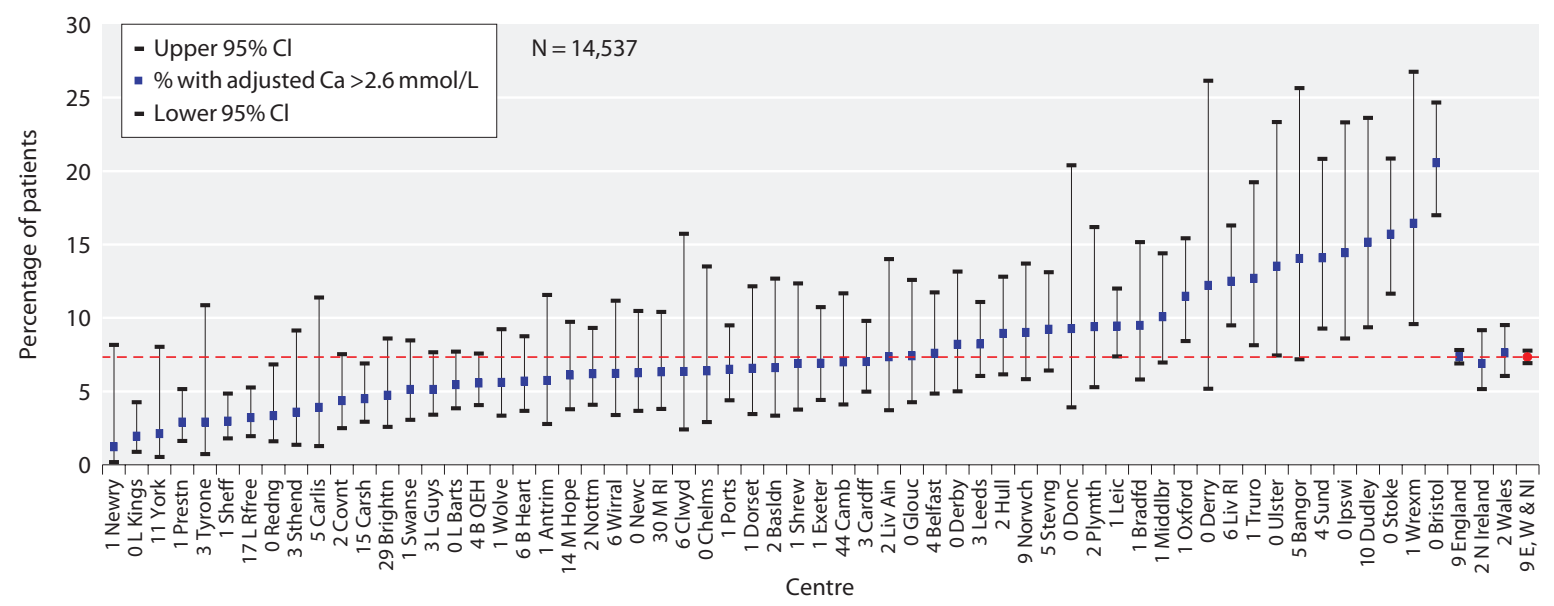

Fig. 10.18. Percentage of haemodialysis patients with adjusted calcium $>2.6 \mathrm{mmol} / \mathrm{L}$ by centre in 2007 


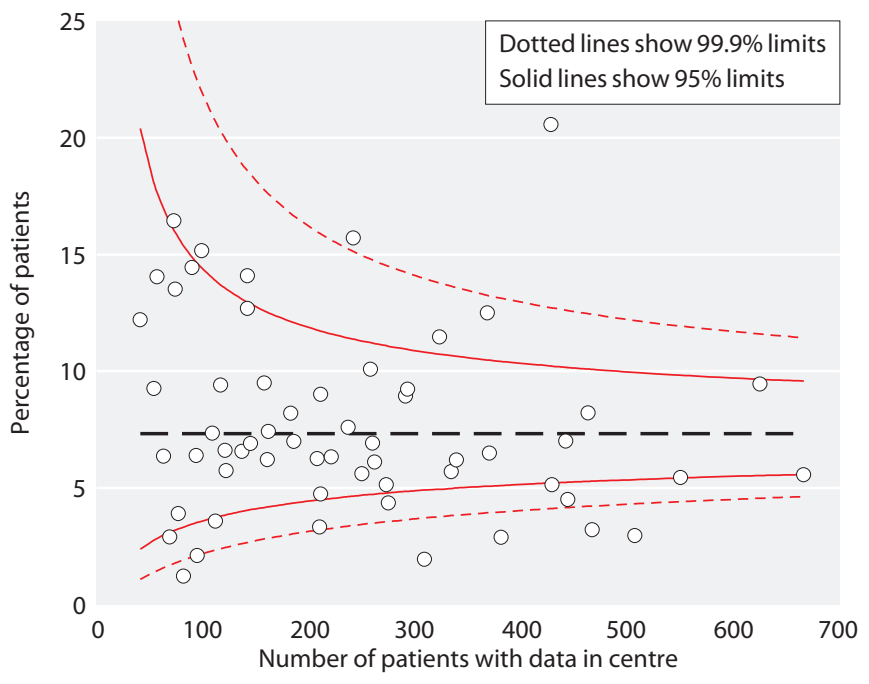

Fig. 10.19. Funnel plot of percentage of haemodialysis patients with adjusted calcium $>2.6 \mathrm{mmol} / \mathrm{L}$ by centre in 2007

Table 10.8. Summary statistics for adjusted calcium in peritoneal dialysis patients in 2007

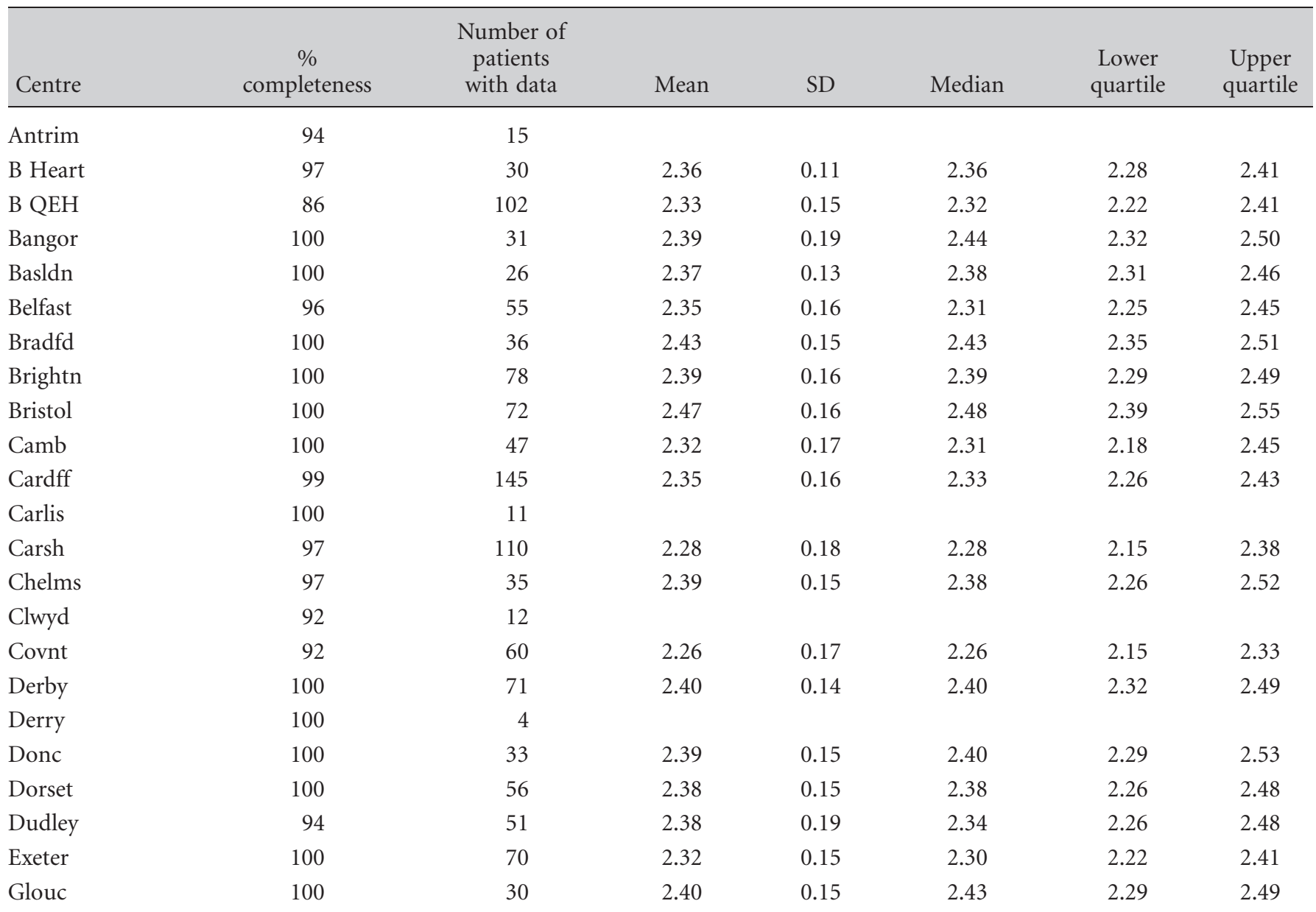


Table 10.8. Continued

\begin{tabular}{|c|c|c|c|c|c|c|c|}
\hline Centre & $\begin{array}{c}\% \\
\text { completeness }\end{array}$ & $\begin{array}{l}\text { Number of } \\
\text { patients } \\
\text { with data }\end{array}$ & Mean & $\mathrm{SD}$ & Median & $\begin{array}{l}\text { Lower } \\
\text { quartile }\end{array}$ & $\begin{array}{c}\text { Upper } \\
\text { quartile }\end{array}$ \\
\hline Hull & 95 & 79 & 2.48 & 0.14 & 2.46 & 2.40 & 2.56 \\
\hline Ipswi & 98 & 44 & 2.44 & 0.14 & 2.44 & 2.37 & 2.52 \\
\hline L Barts & 100 & 217 & 2.37 & 0.20 & 2.34 & 2.24 & 2.47 \\
\hline L Guys & 98 & 59 & 2.37 & 0.14 & 2.38 & 2.26 & 2.45 \\
\hline L Kings & 99 & 74 & 2.29 & 0.14 & 2.29 & 2.22 & 2.36 \\
\hline L Rfree & 95 & 114 & 2.35 & 0.19 & 2.35 & 2.24 & 2.46 \\
\hline L West & 5 & 3 & & & & & \\
\hline Leeds & 99 & 98 & 2.39 & 0.14 & 2.40 & 2.31 & 2.50 \\
\hline Leic & 99 & 179 & 2.42 & 0.16 & 2.42 & 2.32 & 2.53 \\
\hline Liv Ain & $\mathrm{n} / \mathrm{a}$ & 0 & & & & & \\
\hline Liv RI & 92 & 85 & 2.45 & 0.18 & 2.42 & 2.32 & 2.59 \\
\hline M Hope & 95 & 110 & 2.28 & 0.17 & 2.29 & 2.17 & 2.39 \\
\hline M RI & 100 & 115 & 2.31 & 0.16 & 2.32 & 2.23 & 2.41 \\
\hline Middlbr & 92 & 23 & 2.30 & 0.22 & 2.37 & 2.24 & 2.41 \\
\hline Newc & 100 & 46 & 2.43 & 0.20 & 2.43 & 2.27 & 2.56 \\
\hline Newry & 100 & 13 & & & & & \\
\hline Norwch & 96 & 55 & 2.44 & 0.13 & 2.47 & 2.37 & 2.53 \\
\hline Nottm & 100 & 135 & 2.46 & 0.14 & 2.46 & 2.38 & 2.54 \\
\hline Oxford & 100 & 133 & 2.40 & 0.19 & 2.42 & 2.31 & 2.52 \\
\hline Plymth & 100 & 38 & 2.45 & 0.17 & 2.48 & 2.34 & 2.55 \\
\hline Ports & 83 & 76 & 2.40 & 0.19 & 2.39 & 2.29 & 2.51 \\
\hline Prestn & 99 & 76 & 2.38 & 0.17 & 2.38 & 2.24 & 2.50 \\
\hline Redng & 100 & 86 & 2.37 & 0.15 & 2.37 & 2.27 & 2.47 \\
\hline Sheff & 100 & 88 & 2.40 & 0.15 & 2.41 & 2.31 & 2.50 \\
\hline Shrew & 94 & 31 & 2.43 & 0.21 & 2.40 & 2.30 & 2.60 \\
\hline Stevng & 100 & 38 & 2.42 & 0.16 & 2.39 & 2.34 & 2.54 \\
\hline Sthend & 94 & 17 & & & & & \\
\hline Stoke & 100 & 90 & 2.51 & 0.18 & 2.49 & 2.42 & 2.59 \\
\hline Sund & 100 & 10 & & & & & \\
\hline Swanse & 96 & 71 & 2.28 & 0.14 & 2.27 & 2.20 & 2.36 \\
\hline Truro & 100 & 23 & 2.36 & 0.14 & 2.33 & 2.27 & 2.48 \\
\hline Ulster & 100 & 2 & & & & & \\
\hline Wirral & 68 & 19 & & & & & \\
\hline Wolve & 98 & 52 & 2.33 & 0.16 & 2.31 & 2.25 & 2.40 \\
\hline Wrexm & 90 & 27 & 2.45 & 0.14 & 2.43 & 2.34 & 2.52 \\
\hline York & 96 & 22 & 2.36 & 0.12 & 2.38 & 2.29 & 2.46 \\
\hline England & 95 & 3,153 & 2.38 & 0.18 & 2.38 & 2.27 & 2.49 \\
\hline $\mathrm{N}$ Ireland & 97 & 94 & 2.35 & 0.16 & 2.32 & 2.25 & 2.45 \\
\hline Wales & 97 & 286 & 2.34 & 0.16 & 2.33 & 2.25 & 2.44 \\
\hline $\mathrm{E}, \mathrm{W} \& \mathrm{NI}$ & 96 & 3,533 & 2.38 & 0.18 & 2.38 & 2.27 & 2.48 \\
\hline
\end{tabular}

Blank cells denote centres excluded from analyses due to low patient numbers or poor data completeness n/a not applicable 
Table 10.9. Percentage of peritoneal dialysis patients within, below and above the range for adjusted calcium (2.2-2.6 mmol/L) in 2007

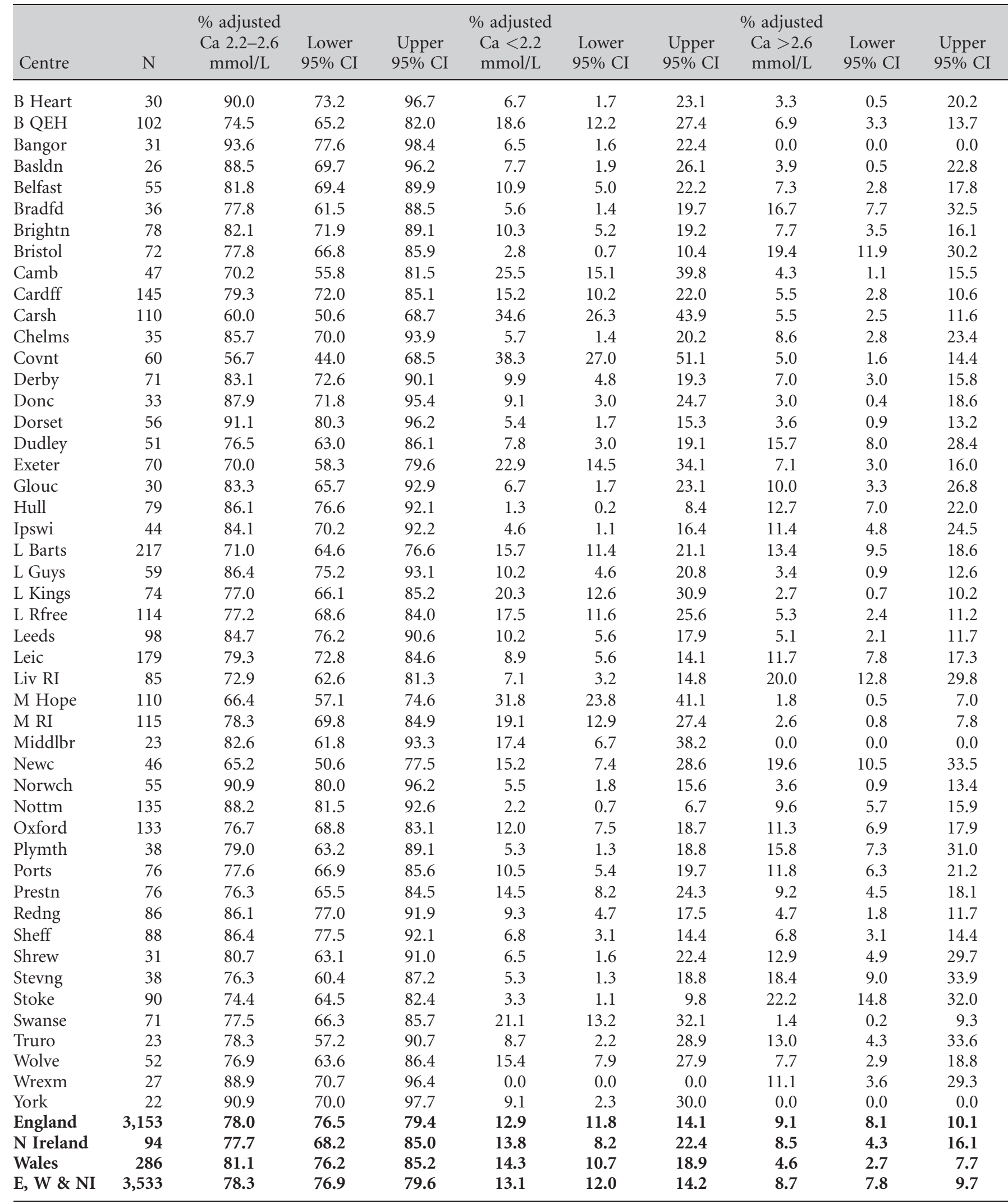




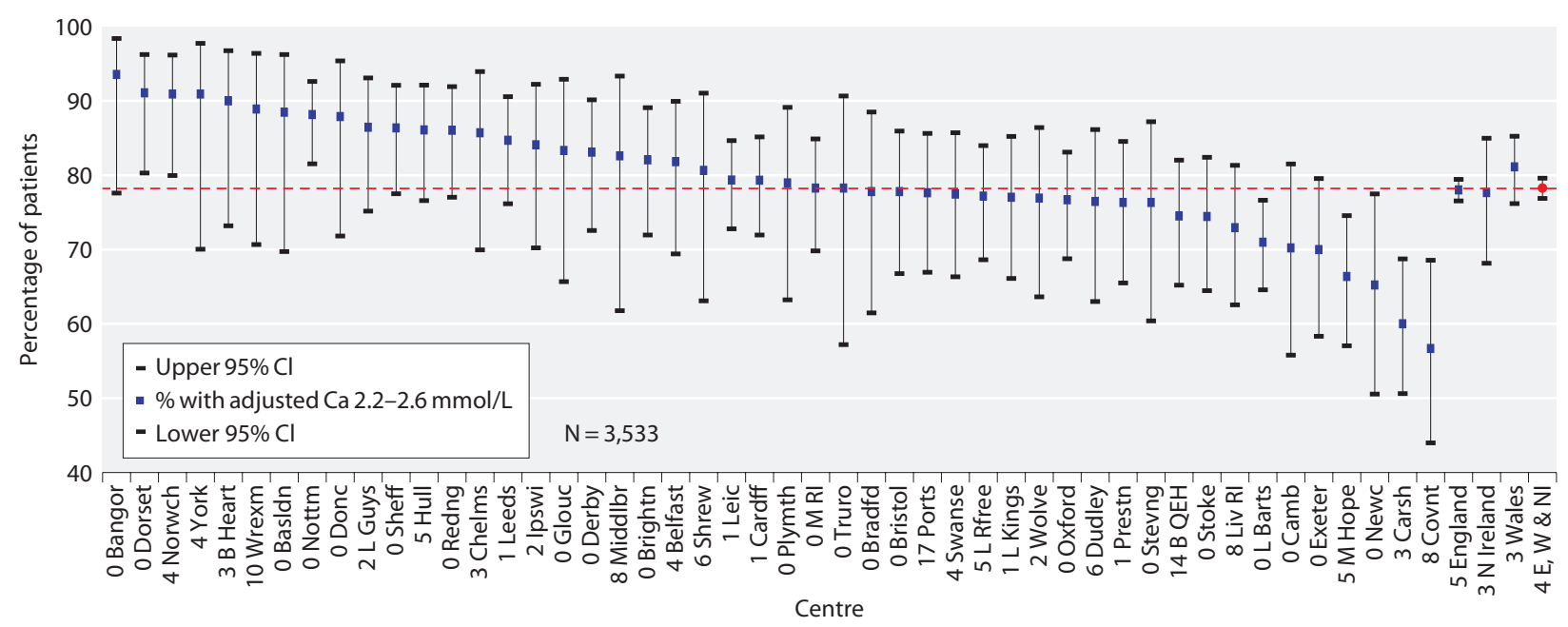

Fig. 10.20. Percentage of peritoneal dialysis patients with adjusted calcium $2.2-2.6 \mathrm{mmol} / \mathrm{L}$ by centre in 2007

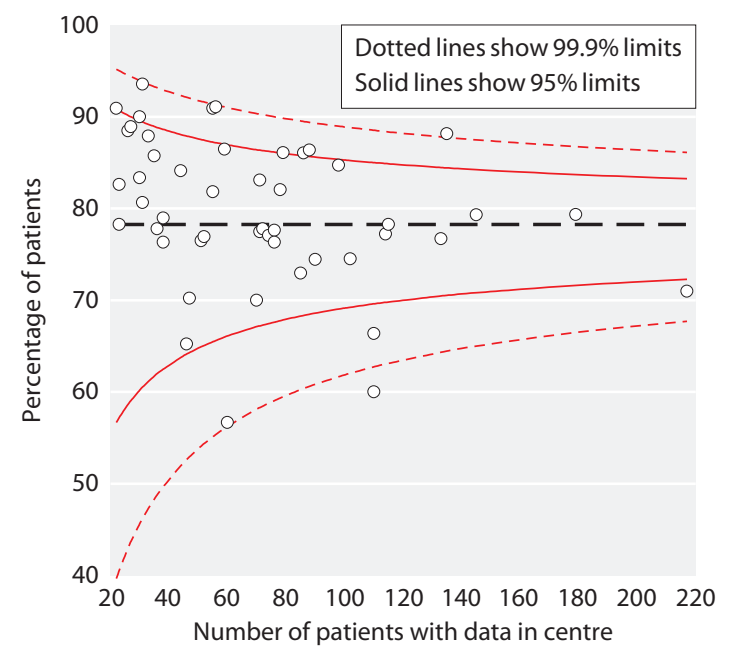

Fig. 10.21. Funnel plot of percentage of peritoneal dialysis patients with adjusted calcium $2.2-2.6 \mathrm{mmol} / \mathrm{L}$ by centre in 2007

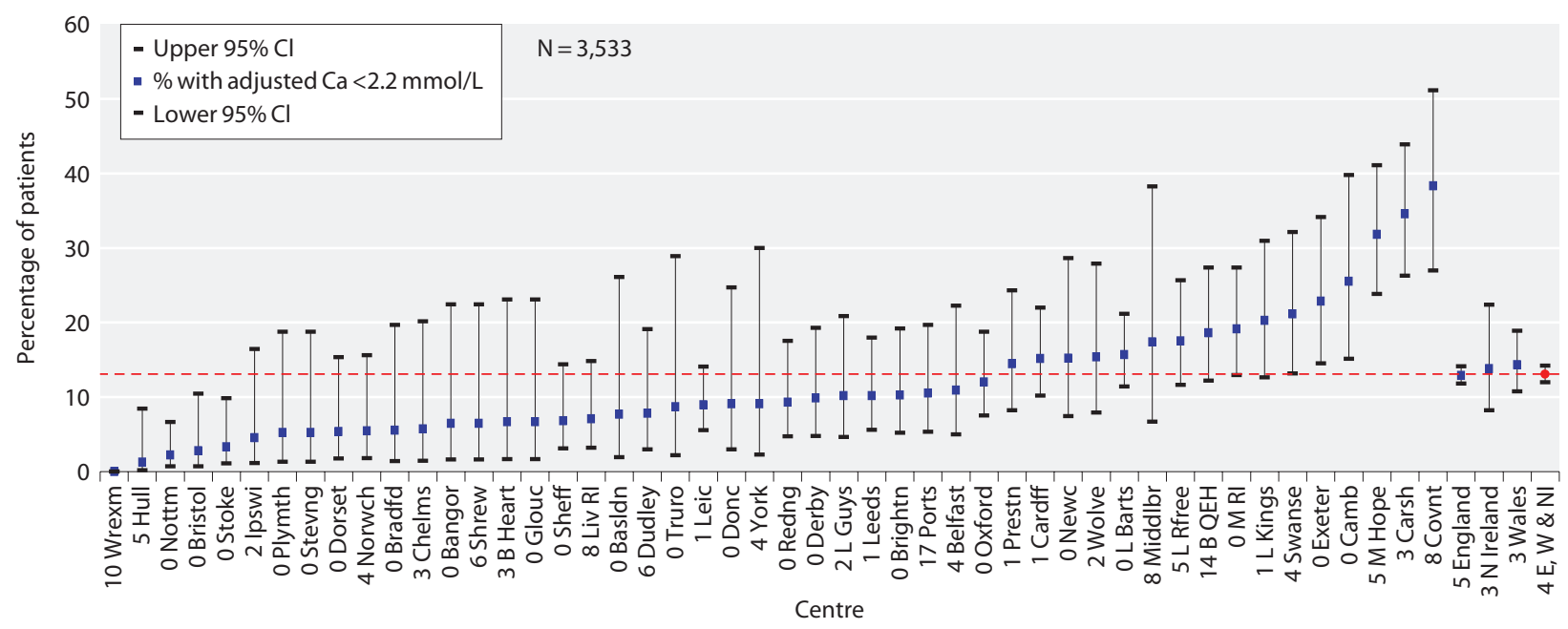

Fig. 10.22. Percentage of peritoneal dialysis patients with adjusted calcium $<2.2 \mathrm{mmol} / \mathrm{L}$ by centre in 2007 


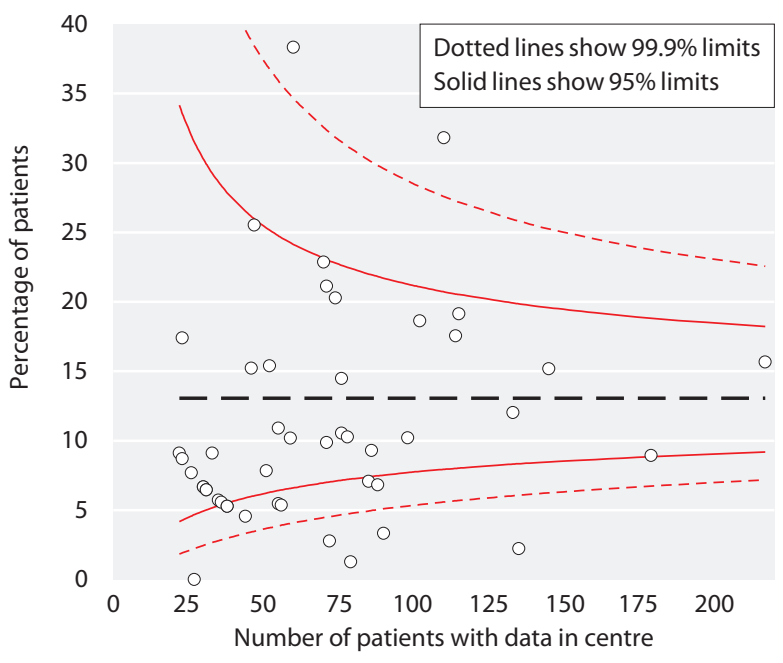

Fig. 10.23. Funnel plot of percentage of peritoneal dialysis patients with adjusted calcium $<2.2 \mathrm{mmol} / \mathrm{L}$ by centre in 2007

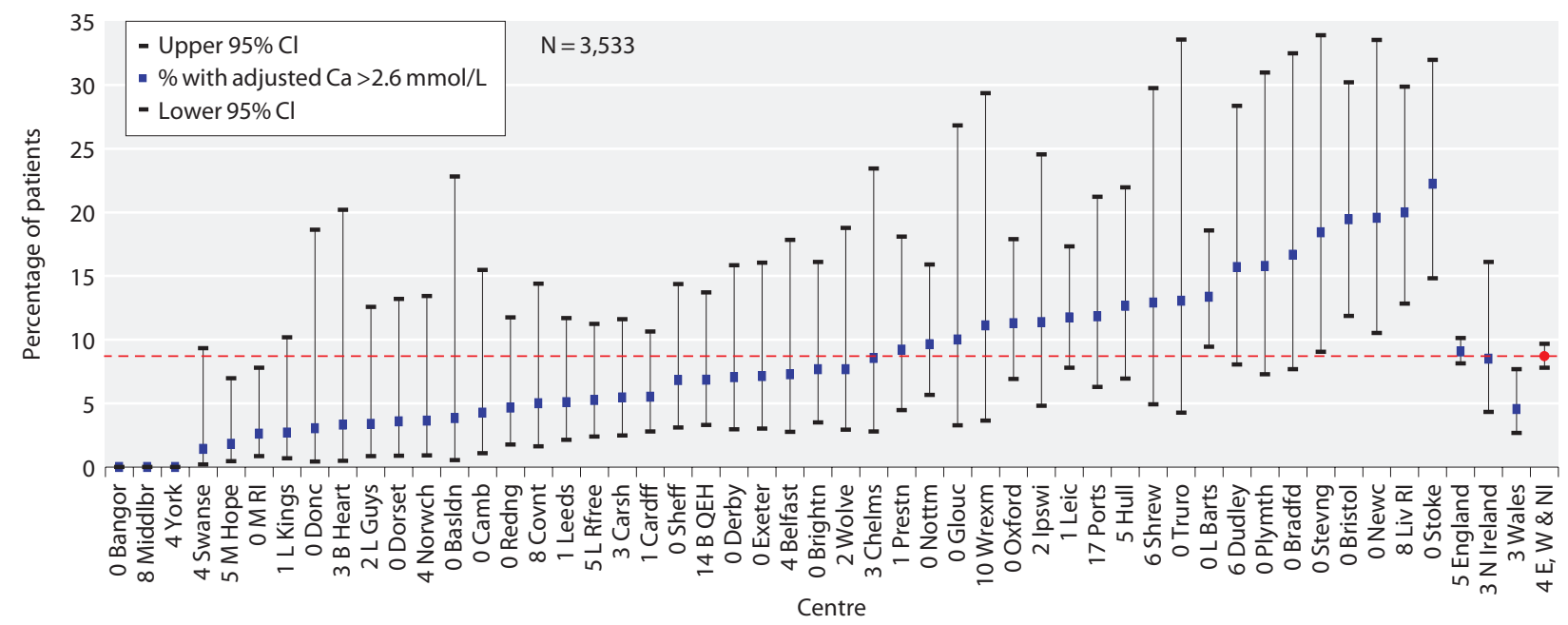

Fig. 10.24. Percentage of peritoneal dialysis patients with adjusted calcium $>2.6 \mathrm{mmol} / \mathrm{L}$ by centre in 2007

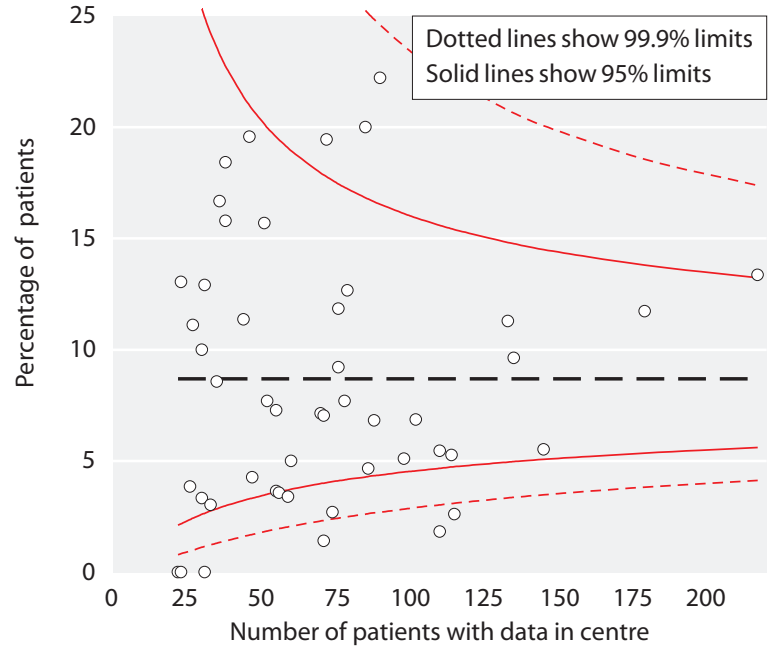

UK management of biochemical variables
Fig. 10.25. Funnel plot of percentage of peritoneal dialysis patients with adjusted calcium $>2.6 \mathrm{mmol} / \mathrm{L}$ by centre in 2007 


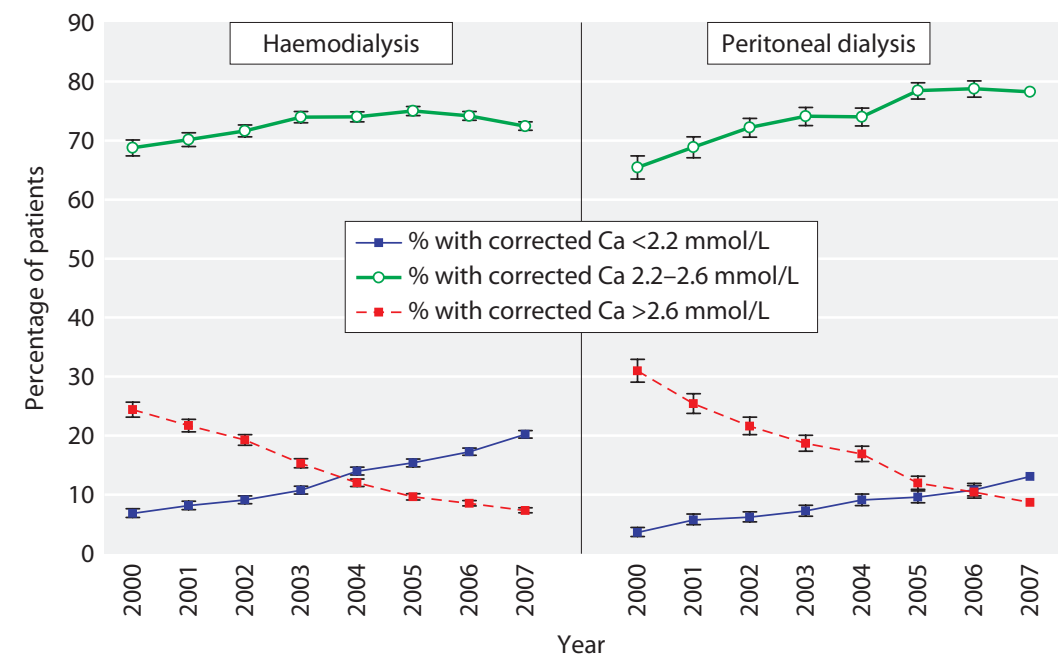

Fig. 10.26. Longitudinal change in percentage of patients with adjusted calcium $<2.2 \mathrm{mmol} / \mathrm{L}, 2.2-2.6 \mathrm{mmol} / \mathrm{L}$ and $>2.6 \mathrm{mmol} / \mathrm{L}$ by dialysis modality 2000-2007

\section{Parathyroid hormone}

The 4th edition of the Renal Association clinical practice guidelines states:

'The target range for parathyroid hormone measured using an intact PTH assay should be between 2 and 4 times the upper limit of normal for the intact PTH assay used. The same target range should apply when using the whole molecule PTH assay.' (Module 2: Complications) [1]

The data for parathyroid hormone were $82 \%$ complete for $\mathrm{HD}$ patients and $84 \%$ complete for PD patients overall although there was between centre variation (tables 10.10 and 10.12). Twenty five percent (CI 24-26\%) of HD patients and 27\% (26-29\%) of PD patients achieved a parathyroid hormone between 16-32 pmol/L (tables
10.11 and 10.13). The proportion of HD patients with a parathyroid hormone above the upper limit of the range was $40 \%$ (CI 40-41\%) and the proportion with parathyroid hormone below the lower limit of the range was 35\% (CI 34-36\%) (table 10.11). The proportion of PD patients with parathyroid hormone above the upper limit of the range was 40\% (CI 39-42\%) and the proportion with parathyroid hormone below the lower limit of the range was 33\% (CI 31-34\%) (table 10.13). The proportion of dialysis patients achieving the Renal Association audit measure has reduced considerably with the introduction of a lower specification of the audit measure. Again there was between centre variation in unadjusted analyses for the proportion of patients below, within and above the range specified by the clinical performance measure (figures 10.27-10.38).

Table 10.10. Summary statistics for PTH in haemodialysis patients in 2007

\begin{tabular}{|c|c|c|c|c|c|c|c|}
\hline Centre & $\begin{array}{c}\% \\
\text { completeness }\end{array}$ & $\begin{array}{c}\text { Number of } \\
\text { patients } \\
\text { with data }\end{array}$ & Mean & $\mathrm{SD}$ & Median & $\begin{array}{c}\text { Lower } \\
\text { quartile }\end{array}$ & $\begin{array}{l}\text { Upper } \\
\text { quartile }\end{array}$ \\
\hline Antrim & 99 & 122 & 32.7 & 33.9 & 22.7 & 11.8 & 41.7 \\
\hline B Heart & 86 & 308 & 41.5 & 38.8 & 29.7 & 15.7 & 56.7 \\
\hline B QEH & 62 & 428 & 24.1 & 15.3 & 22.7 & 11.2 & 36.5 \\
\hline Bangor & 95 & 57 & 27.5 & 32.0 & 20.3 & 8.1 & 34.1 \\
\hline Basldn & 98 & 121 & 43.4 & 49.0 & 29.9 & 13.8 & 49.8 \\
\hline Belfast & 92 & 227 & 40.7 & 35.8 & 29.8 & 15.2 & 53.6 \\
\hline Bradfd & 98 & 156 & 37.9 & 43.1 & 22.5 & 8.9 & 49.2 \\
\hline Brightn & 96 & 287 & 44.5 & 45.3 & 32.5 & 12.6 & 58.8 \\
\hline Bristol & 97 & 413 & 29.3 & 32.3 & 18.5 & 8.3 & 39.2 \\
\hline Camb & 48 & 160 & & & & & \\
\hline Cardff & 90 & 411 & 27.2 & 32.6 & 17.6 & 4.6 & 36.5 \\
\hline Carlis & 94 & 76 & 41.8 & 39.9 & 31.6 & 14.2 & 51.3 \\
\hline
\end{tabular}


Table 10.10. Continued

\begin{tabular}{|c|c|c|c|c|c|c|c|}
\hline Centre & $\begin{array}{c}\% \\
\text { completeness }\end{array}$ & $\begin{array}{c}\text { Number of } \\
\text { patients } \\
\text { with data }\end{array}$ & Mean & $\mathrm{SD}$ & Median & $\begin{array}{c}\text { Lower } \\
\text { quartile }\end{array}$ & $\begin{array}{l}\text { Upper } \\
\text { quartile }\end{array}$ \\
\hline Chelms & 98 & 92 & 42.3 & 44.5 & 26.6 & 16.4 & 53.2 \\
\hline Clwyd & 88 & 59 & 34.1 & 38.3 & 22.0 & 10.0 & 40.0 \\
\hline Covnt & 80 & 224 & 62.9 & 71.3 & 42.0 & 16.5 & 81.0 \\
\hline Donc & 100 & 54 & 50.3 & 52.9 & 28.8 & 9.2 & 71.4 \\
\hline Dorset & 87 & 121 & 34.1 & 29.8 & 27.0 & 12.4 & 44.7 \\
\hline Dudley & 76 & 84 & 54.3 & 102.8 & 23.2 & 9.3 & 47.3 \\
\hline Exeter & 94 & 245 & 22.6 & 32.0 & 12.2 & 4.7 & 26.0 \\
\hline Glouc & 98 & 159 & 28.2 & 35.7 & 17.4 & 9.2 & 31.0 \\
\hline L Kings & 2 & 5 & & & & & \\
\hline L Rfree & 79 & 448 & 36.2 & 36.7 & 25.0 & 13.0 & 46.5 \\
\hline L West & 24 & 238 & & & & & \\
\hline Leeds & 95 & 450 & 27.3 & 27.3 & 18.2 & 10.1 & 34.8 \\
\hline Leic & 96 & 610 & 39.7 & 39.9 & 28.8 & 9.7 & 57.7 \\
\hline Liv Ain & 76 & 84 & 29.8 & 36.9 & 18.5 & 9.0 & 31.5 \\
\hline Liv RI & 90 & 355 & 39.9 & 39.2 & 27.0 & 15.0 & 52.0 \\
\hline M Hope & 80 & 245 & 34.8 & 44.1 & 18.3 & 8.0 & 37.4 \\
\hline M RI & 65 & 203 & 42.0 & 38.9 & 32.8 & 12.2 & 56.8 \\
\hline Middlbr & 90 & 234 & 54.7 & 90.9 & 29.8 & 14.5 & 60.0 \\
\hline Newc & 98 & 204 & 32.9 & 30.1 & 23.5 & 13.0 & 40.9 \\
\hline Sheff & 98 & 502 & 51.0 & 47.7 & 37.3 & 17.2 & 69.6 \\
\hline Shrew & 95 & 140 & 36.0 & 34.8 & 24.9 & 12.6 & 41.7 \\
\hline Stevng & 96 & 296 & 47.8 & 43.3 & 38.0 & 19.0 & 57.0 \\
\hline Sthend & 92 & 106 & 56.6 & 47.9 & 44.3 & 22.6 & 80.5 \\
\hline Stoke & 97 & 234 & 41.5 & 41.9 & 28.7 & 14.2 & 51.9 \\
\hline Sund & 97 & 144 & 25.3 & 27.9 & 14.3 & 6.6 & 33.5 \\
\hline Swanse & 97 & 266 & 43.9 & 127.5 & 20.2 & 9.2 & 52.9 \\
\hline Truro & 99 & 142 & 32.1 & 35.3 & 22.9 & 10.6 & 40.5 \\
\hline Tyrone & 96 & 68 & 43.2 & 30.7 & 34.8 & 22.9 & 58.0 \\
\hline Ulster & 100 & 74 & 36.4 & 32.2 & 25.1 & 13.8 & 46.7 \\
\hline Wirral & 64 & 109 & 40.6 & 40.4 & 28.1 & 14.3 & 53.2 \\
\hline Wolve & 99 & 251 & 25.8 & 35.8 & 14.1 & 6.2 & 30.5 \\
\hline Wrexm & 91 & 67 & 24.2 & 28.5 & 12.9 & 5.5 & 34.7 \\
\hline York & 98 & 105 & 31.7 & 36.5 & 21.8 & 11.2 & 35.7 \\
\hline England & 80 & 11,508 & 38.9 & 44.8 & 25.2 & 11.2 & 49.7 \\
\hline N Ireland & 96 & 612 & 40.6 & 37.9 & 28.6 & 15.2 & 52.8 \\
\hline Wales & 92 & 860 & 32.6 & 76.2 & 18.5 & 6.8 & 40.1 \\
\hline $\mathrm{E}, \mathrm{W} \& \mathrm{NI}$ & 82 & 12,980 & 38.6 & 47.2 & 24.9 & 11.0 & 49.3 \\
\hline
\end{tabular}

Blank cells denote centres excluded from analyses due to low patient numbers or poor data completeness 
Table 10.11. Percentage of haemodialysis patients within, below and above the range for PTH (16-32 pmol/L) in 2007

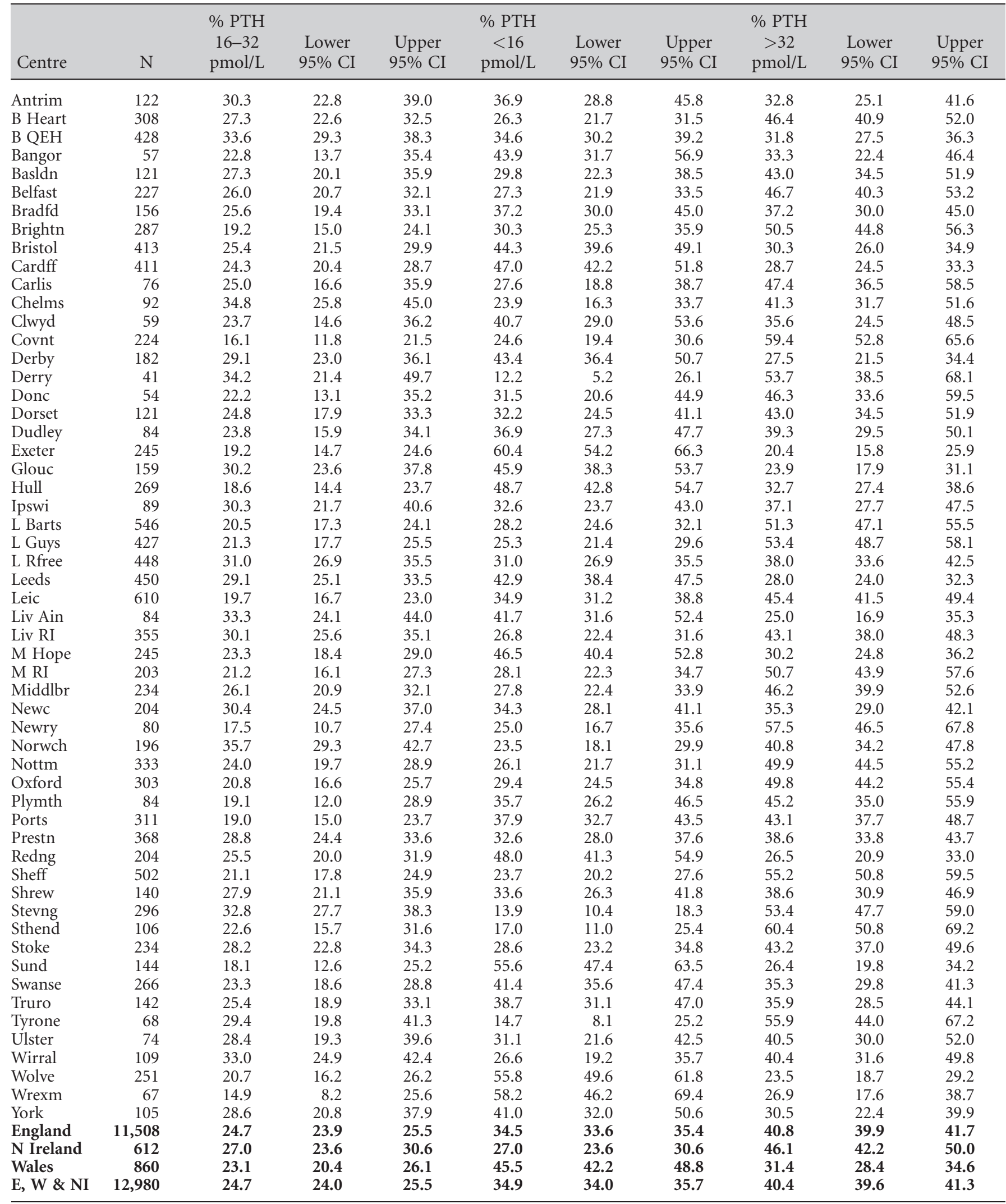




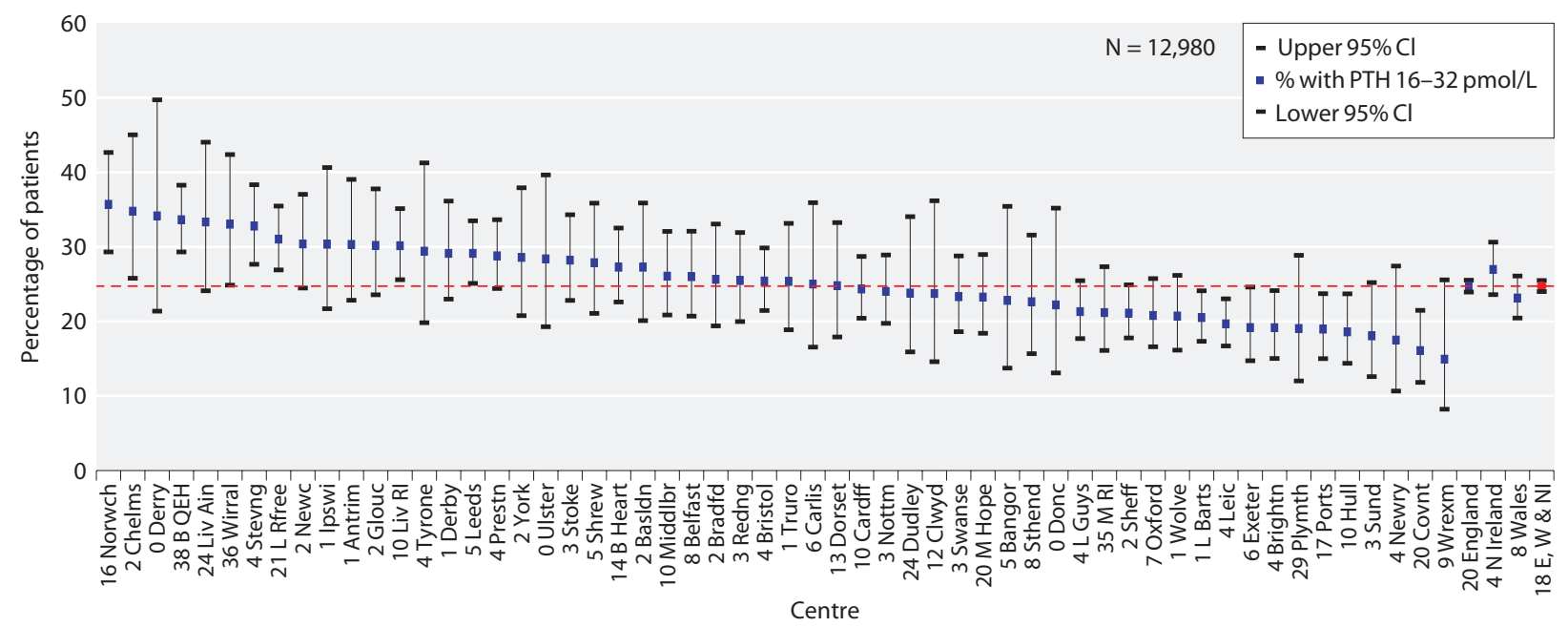

Fig. 10.27. Percentage of haemodialysis patients with PTH $16-32 \mathrm{pmol} / \mathrm{L}$ by centre in 2007

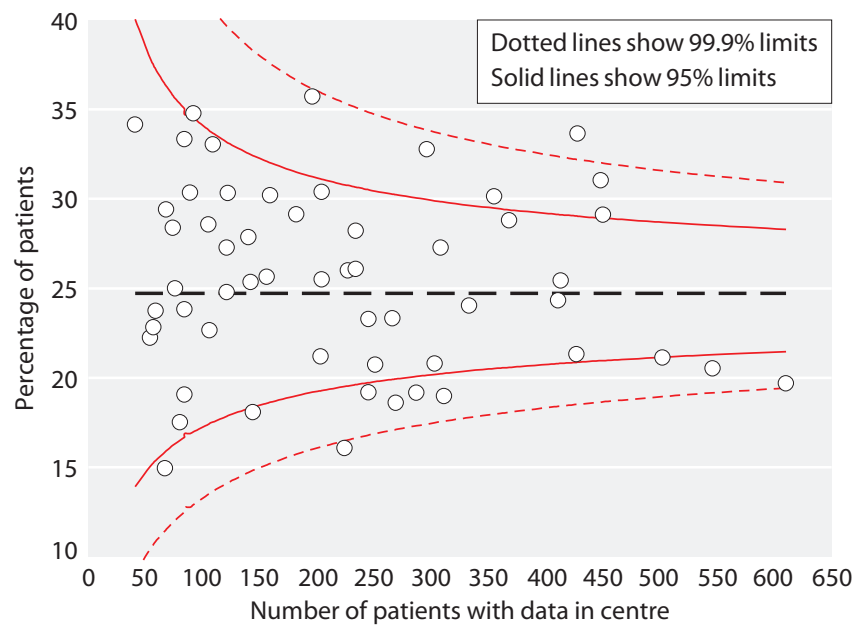

Fig. 10.28. Funnel plot of percentage of haemodialysis patients with PTH 16-32 pmol/L by centre in 2007

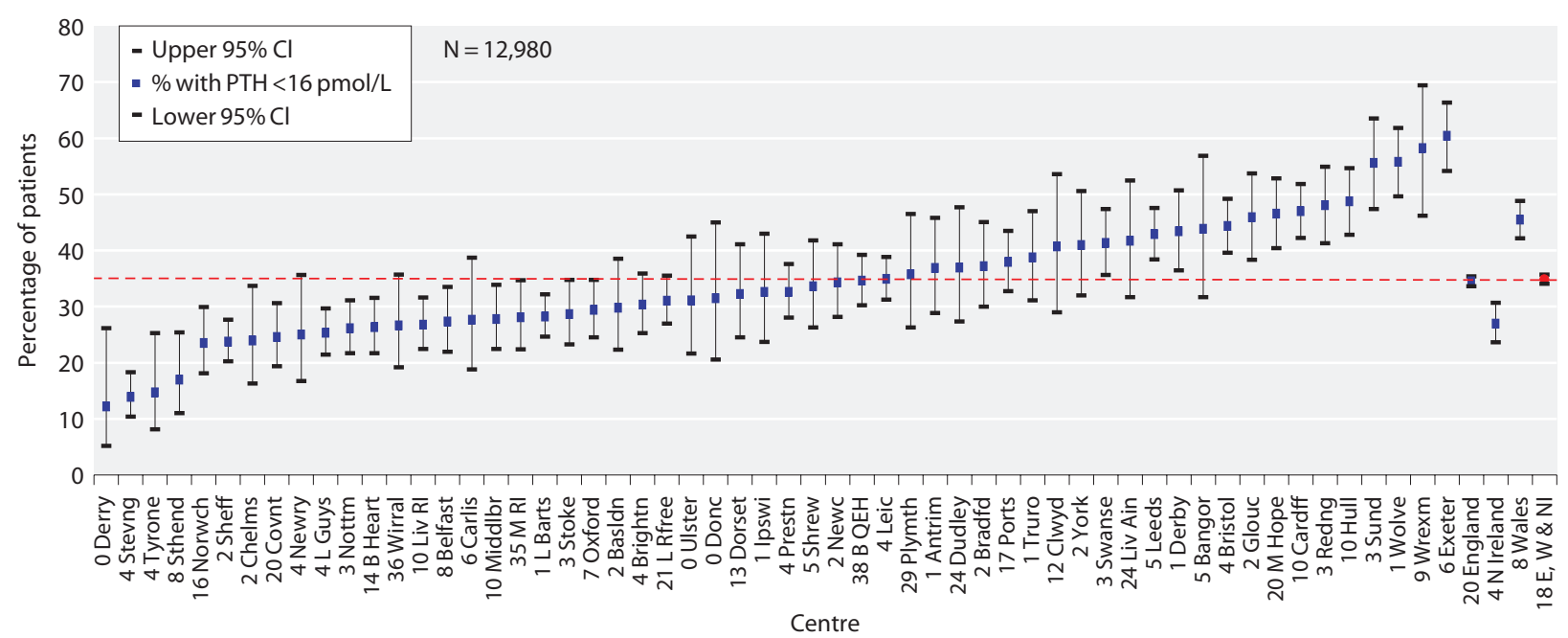

Fig. 10.29. Percentage of haemodialysis patients with $\mathrm{PTH}<16 \mathrm{pmol} / \mathrm{L}$ by centre in 2007 


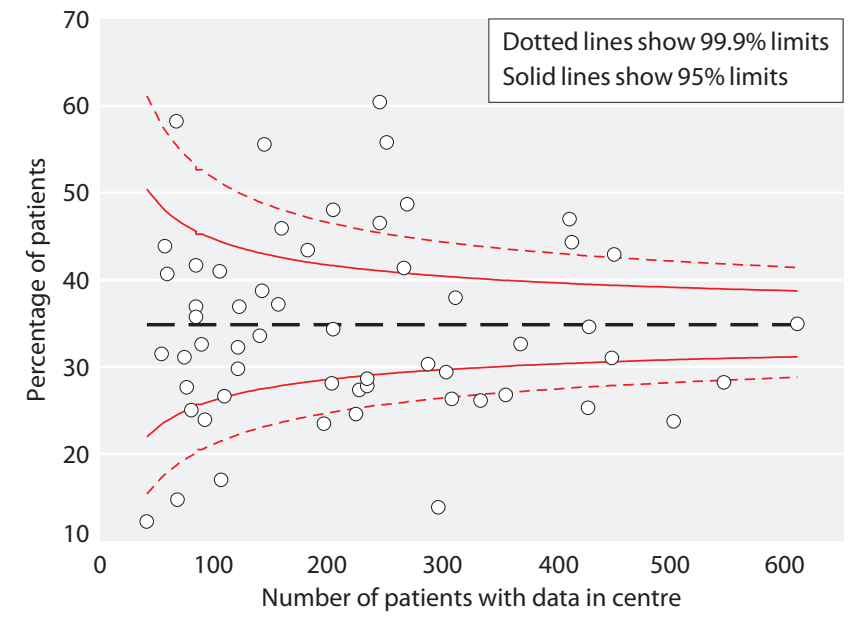

Fig. 10.30. Funnel plot of percentage of haemodialysis patients with $\mathrm{PTH}<16 \mathrm{pmol} / \mathrm{L}$ by centre in 2007

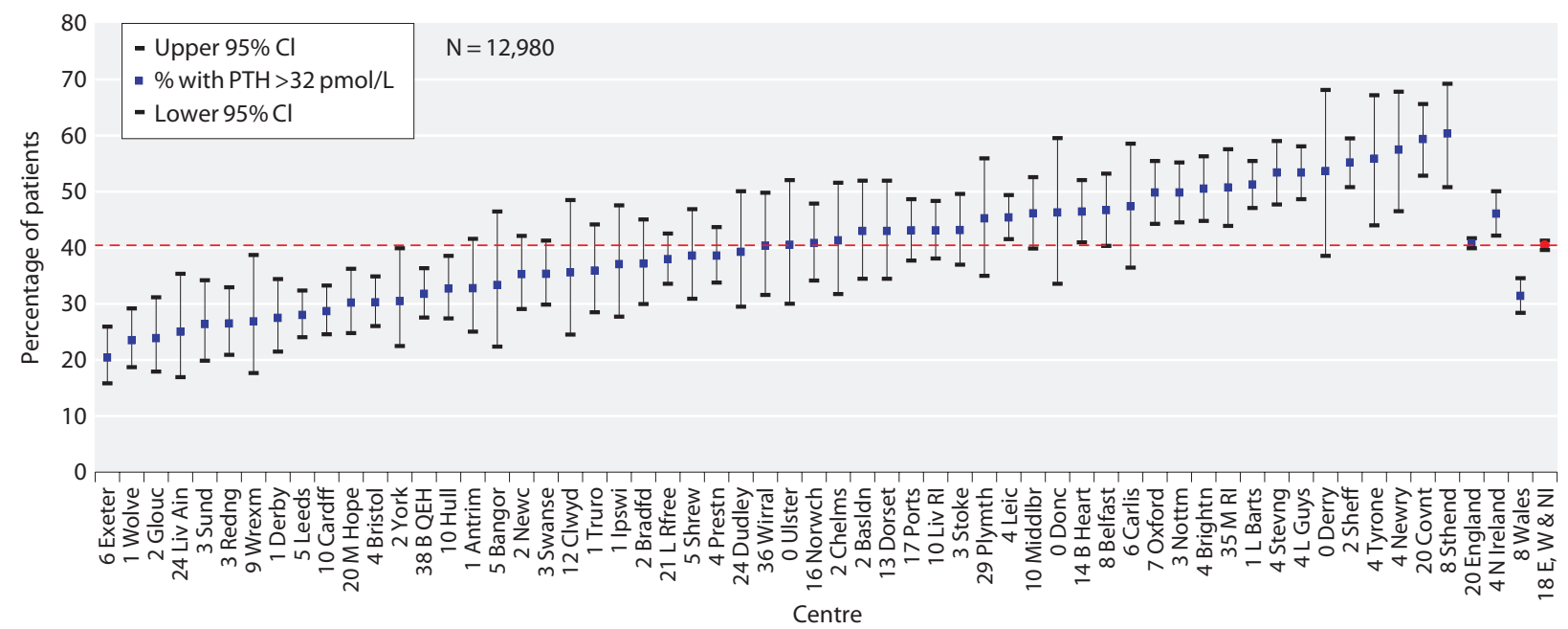

Fig. 10.31. Percentage of haemodialysis patients with PTH $>32 \mathrm{pmol} / \mathrm{L}$ by centre in 2007

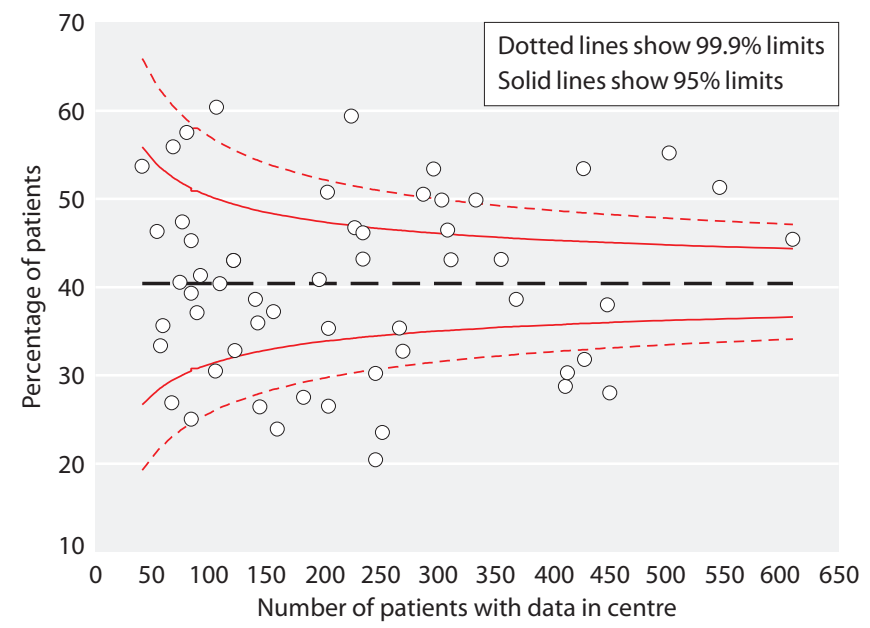

c210
Fig. 10.32. Funnel plot of percentage of haemodialysis patients with $\mathrm{PTH}>32 \mathrm{pmol} / \mathrm{L}$ by centre in 2007 
Table 10.12. Summary statistics for PTH in peritoneal dialysis patients in 2007

\begin{tabular}{|c|c|c|c|c|c|c|c|}
\hline Centre & $\begin{array}{c}\% \\
\text { completeness }\end{array}$ & $\begin{array}{c}\text { Number of } \\
\text { patients with data }\end{array}$ & Mean & SD & Median & $\begin{array}{l}\text { Lower } \\
\text { quartile }\end{array}$ & $\begin{array}{l}\text { Upper } \\
\text { quartile }\end{array}$ \\
\hline Antrim & 94 & 15 & & & & & \\
\hline B QEH & 73 & 86 & 22.1 & 16.3 & 18.9 & 8.2 & 36.2 \\
\hline Bangor & 100 & 31 & 27.5 & 32.0 & 16.8 & 7.4 & 28.6 \\
\hline Basldn & 100 & 26 & 43.3 & 28.3 & 34.6 & 21.9 & 65.7 \\
\hline Belfast & 93 & 53 & 54.6 & 36.7 & 47.4 & 22.4 & 79.7 \\
\hline Bristol & 96 & 69 & 44.6 & 48.7 & 24.2 & 10.5 & 56.2 \\
\hline Camb & 96 & 45 & 34.0 & 30.4 & 25.5 & 15.3 & 39.7 \\
\hline Cardff & 97 & 143 & 51.9 & 41.4 & 40.4 & 21.5 & 67.2 \\
\hline Carlis & 100 & 11 & & & & & \\
\hline Carsh & 7 & 8 & & & & & \\
\hline Chelms & 94 & 34 & 35.9 & 27.4 & 33.2 & 20.2 & 40.9 \\
\hline Clwyd & 77 & 10 & & & & & \\
\hline Dudley & 74 & 40 & 46.3 & 43.0 & 31.9 & 15.7 & 66.9 \\
\hline Exeter & 99 & 69 & 24.8 & 20.6 & 19.9 & 9.0 & 30.3 \\
\hline Glouc & 87 & 26 & 22.6 & 18.4 & 20.1 & 12.1 & 28.0 \\
\hline Hull & 69 & 57 & 29.4 & 41.9 & 19.1 & 8.7 & 30.8 \\
\hline Ipswi & 96 & 43 & 41.9 & 37.1 & 32.2 & 19.5 & 53.2 \\
\hline L Barts & 89 & 193 & 32.7 & 36.6 & 19.5 & 9.0 & 41.0 \\
\hline L Guys & 93 & 56 & 38.1 & 37.0 & 25.1 & 13.7 & 51.5 \\
\hline L Kings & 1 & 1 & & & & & \\
\hline L Rfree & 94 & 113 & 26.8 & 21.1 & 22.0 & 12.0 & 34.0 \\
\hline L West & 56 & 36 & 41.5 & 31.6 & 26.7 & 18.1 & 69.6 \\
\hline Leeds & 98 & 97 & 34.7 & 33.7 & 26.4 & 13.1 & 47.4 \\
\hline Leic & 93 & 167 & 41.0 & 38.1 & 35.9 & 15.8 & 53.9 \\
\hline Liv Ain & $\mathrm{n} / \mathrm{a}$ & 0 & & & & & \\
\hline Liv RI & 85 & 78 & 34.8 & 31.1 & 23.0 & 13.0 & 50.0 \\
\hline M Hope & 86 & 100 & 25.0 & 22.9 & 19.8 & 7.0 & 31.4 \\
\hline Prestn & 97 & 75 & 44.4 & 31.7 & 35.7 & 23.4 & 62.7 \\
\hline Redng & 98 & 84 & 25.0 & 21.1 & 20.1 & 13.2 & 29.6 \\
\hline Sheff & 85 & 75 & 56.1 & 44.5 & 49.6 & 25.8 & 69.8 \\
\hline Shrew & 97 & 32 & 25.8 & 26.2 & 16.6 & 8.5 & 29.2 \\
\hline Stevng & 87 & 33 & 54.5 & 45.1 & 38.0 & 28.5 & 66.5 \\
\hline Sthend & 72 & 13 & & & & & \\
\hline Stoke & 92 & 83 & 52.5 & 50.8 & 39.7 & 14.5 & 69.1 \\
\hline Sund & 90 & 9 & & & & & \\
\hline Swanse & 95 & 70 & 36.8 & 28.0 & 29.3 & 15.8 & 53.9 \\
\hline Truro & 96 & 22 & 36.2 & 55.9 & 20.0 & 7.1 & 51.2 \\
\hline Tyrone & 100 & 5 & & & & & \\
\hline Ulster & 100 & 2 & & & & & \\
\hline Wirral & 64 & 18 & & & & & \\
\hline Wolve & 92 & 49 & 27.4 & 40.0 & 17.7 & 9.8 & 25.7 \\
\hline Wrexm & 77 & 23 & 36.7 & 46.6 & 20.5 & 7.1 & 43.3 \\
\hline York & 96 & 22 & 26.2 & 25.1 & 20.1 & 7.3 & 31.6 \\
\hline England & 83 & 2,731 & 35.2 & 35.8 & 24.1 & 11.9 & 46.9 \\
\hline N Ireland & 93 & 90 & 44.3 & 34.8 & 32.2 & 19.9 & 64.7 \\
\hline Wales & 94 & 277 & 44.5 & 41.1 & 33.5 & 15.3 & 58.7 \\
\hline E, W \& NI & 84 & 3,098 & 36.3 & 36.4 & 25.0 & 12.2 & 48.0 \\
\hline
\end{tabular}

Blank cells denote centres excluded from analyses due to low patient numbers or poor data completeness n/a not applicable 
Table 10.13. Percentage of peritoneal dialysis patients within, below and above the range for PTH (16-32 pmol/L) in 2007

\begin{tabular}{|c|c|c|c|c|c|c|c|c|c|c|}
\hline Centre & $\mathrm{N}$ & $\begin{array}{c}\% \text { PTH } \\
16-32 \\
\mathrm{pmol} / \mathrm{L}\end{array}$ & $\begin{array}{l}\text { Lower } \\
5 \% \text { CI }\end{array}$ & $\begin{array}{l}\text { Upper } \\
95 \% \text { CI }\end{array}$ & $\begin{array}{c}\% \mathrm{PTH} \\
<16 \\
\mathrm{pmol} / \mathrm{L}\end{array}$ & $\begin{array}{l}\text { Lower } \\
95 \% \text { CI }\end{array}$ & $\begin{array}{l}\text { Upper } \\
95 \% \text { CI }\end{array}$ & $\begin{array}{c}\% \mathrm{PTH} \\
>32 \\
\mathrm{pmol} / \mathrm{L}\end{array}$ & $\begin{array}{l}\text { Lower } \\
95 \% \text { CI }\end{array}$ & $\begin{array}{l}\text { Upper } \\
95 \% \text { CI }\end{array}$ \\
\hline B QEH & 86 & 26.7 & 18.5 & 37.1 & 45.4 & 35.2 & 55.9 & 27.9 & 19.5 & 38.3 \\
\hline Bangor & 31 & 29.0 & 15.9 & 47.1 & 48.4 & 31.7 & 65.5 & 22.6 & 11.2 & 40.4 \\
\hline Basldn & 26 & 30.8 & 16.2 & 50.6 & 15.4 & 5.9 & 34.5 & 53.9 & 35.1 & 71.6 \\
\hline Bradfd & 32 & 18.8 & 8.7 & 35.9 & 28.1 & 15.3 & 45.8 & 53.1 & 36.1 & 69.4 \\
\hline Brightn & 76 & 39.5 & 29.2 & 50.8 & 26.3 & 17.7 & 37.3 & 34.2 & 24.5 & 45.5 \\
\hline Bristol & 69 & 18.8 & 11.3 & 29.8 & 37.7 & 27.1 & 49.6 & 43.5 & 32.3 & 55.3 \\
\hline Camb & 45 & 37.8 & 24.9 & 52.6 & 26.7 & 15.8 & 41.3 & 35.6 & 23.1 & 50.4 \\
\hline Cardff & 143 & 18.9 & 13.3 & 26.1 & 18.2 & 12.7 & 25.4 & 62.9 & 54.7 & 70.5 \\
\hline Dudley & 40 & 25.0 & 14.0 & 40.5 & 25.0 & 14.0 & 40.5 & 50.0 & 35.0 & 65.0 \\
\hline Exeter & 69 & 34.8 & 24.5 & 46.7 & 40.6 & 29.7 & 52.5 & 24.6 & 15.9 & 36.1 \\
\hline Glouc & 26 & 50.0 & 31.7 & 68.3 & 30.8 & 16.2 & 50.6 & 19.2 & 8.2 & 38.7 \\
\hline Hull & 57 & 31.6 & 20.9 & 44.7 & 43.9 & 31.7 & 56.9 & 24.6 & 15.1 & 37.3 \\
\hline Ipswi & 43 & 27.9 & 16.6 & 43.0 & 20.9 & 11.3 & 35.6 & 51.2 & 36.6 & 65.6 \\
\hline L Barts & 193 & 22.3 & 17.0 & 28.7 & 41.5 & 34.7 & 48.5 & 36.3 & 29.8 & 43.3 \\
\hline L Guys & 56 & 33.9 & 22.8 & 47.2 & 30.4 & 19.8 & 43.5 & 35.7 & 24.3 & 49.0 \\
\hline L Rfree & 113 & 34.5 & 26.3 & 43.7 & 36.3 & 28.0 & 45.5 & 29.2 & 21.6 & 38.2 \\
\hline L West & 36 & 27.8 & 15.7 & 44.4 & 25.0 & 13.6 & 41.5 & 47.2 & 31.7 & 63.3 \\
\hline Leeds & 97 & 24.7 & 17.2 & 34.3 & 32.0 & 23.5 & 41.9 & 43.3 & 33.8 & 53.3 \\
\hline Leic & 167 & 19.8 & 14.4 & 26.5 & 25.2 & 19.2 & 32.3 & 55.1 & 47.5 & 62.5 \\
\hline Plymth & 23 & 52.2 & 32.5 & 71.2 & 30.4 & 15.3 & 51.5 & 17.4 & 6.7 & 38.2 \\
\hline Ports & 52 & 17.3 & 9.3 & 30.0 & 26.9 & 16.6 & 40.5 & 55.8 & 42.2 & 68.6 \\
\hline Prestn & 75 & 28.0 & 19.0 & 39.2 & 14.7 & 8.3 & 24.6 & 57.3 & 46.0 & 68.0 \\
\hline Redng & 84 & 45.2 & 35.0 & 55.9 & 34.5 & 25.2 & 45.3 & 20.2 & 13.0 & 30.2 \\
\hline Sheff & 75 & 17.3 & 10.3 & 27.6 & 14.7 & 8.3 & 24.6 & 68.0 & 56.7 & 77.5 \\
\hline Shrew & 32 & 31.3 & 17.7 & 49.0 & 46.9 & 30.6 & 63.9 & 21.9 & 10.8 & 39.3 \\
\hline Stevng & 33 & 24.2 & 12.6 & 41.5 & 9.1 & 3.0 & 24.7 & 66.7 & 49.2 & 80.5 \\
\hline Stoke & 83 & 18.1 & 11.2 & 27.8 & 25.3 & 17.1 & 35.7 & 56.6 & 45.8 & 66.8 \\
\hline Swanse & 70 & 27.1 & 18.0 & 38.7 & 27.1 & 18.0 & 38.7 & 45.7 & 34.5 & 57.4 \\
\hline Truro & 22 & 22.7 & 9.8 & 44.4 & 40.9 & 22.8 & 61.8 & 36.4 & 19.3 & 57.7 \\
\hline Wolve & 49 & 32.7 & 21.1 & 46.8 & 44.9 & 31.7 & 58.9 & 22.5 & 12.9 & 36.2 \\
\hline Wrexm & 23 & 13.0 & 4.3 & 33.6 & 47.8 & 28.8 & 67.5 & 39.1 & 21.8 & 59.8 \\
\hline York & 22 & 36.4 & 19.3 & 57.7 & 40.9 & 22.8 & 61.8 & 22.7 & 9.8 & 44.4 \\
\hline England & 2,731 & 27.4 & 25.8 & 29.1 & 33.9 & 32.1 & 35.7 & 38.7 & 36.9 & 40.6 \\
\hline N Ireland & 90 & 34.4 & 25.4 & 44.8 & 15.6 & 9.4 & 24.6 & 50.0 & 39.8 & 60.2 \\
\hline Wales & 277 & 21.3 & 16.9 & 26.5 & 26.7 & 21.8 & 32.2 & 52.0 & 46.1 & 57.8 \\
\hline $\mathrm{E}, \mathrm{W} \& \mathrm{NI}$ & 3,098 & 27.1 & 25.5 & 28.6 & 32.7 & 31.1 & 34.4 & 40.3 & 38.5 & 42.0 \\
\hline
\end{tabular}




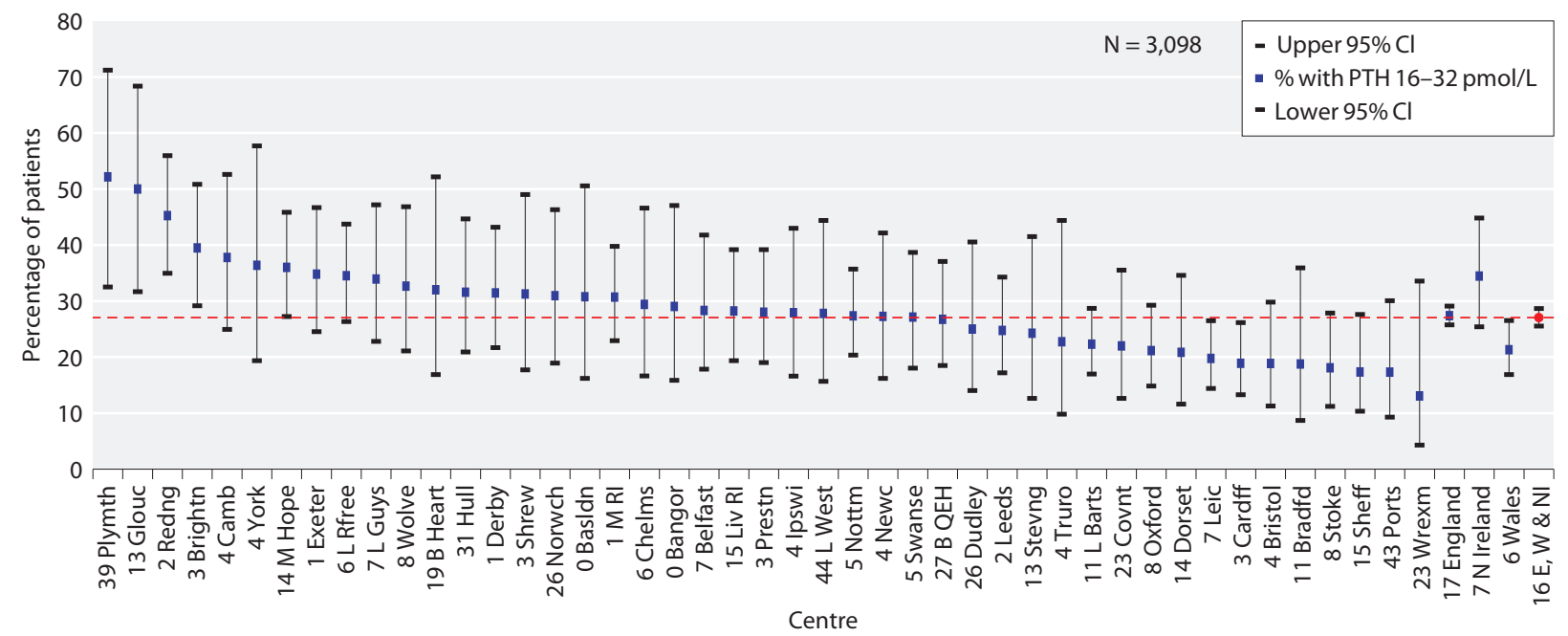

Fig. 10.33. Percentage of peritoneal dialysis patients with PTH 16-32 pmol/L by centre in 2007

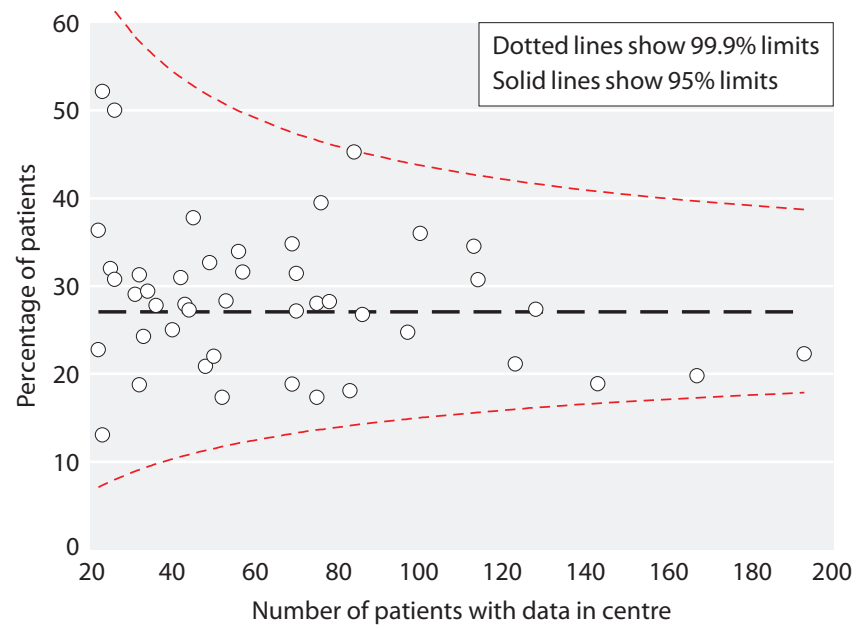

Fig. 10.34. Funnel plot of percentage of peritoneal dialysis patients with PTH 16-32 pmol/L by centre in 2007

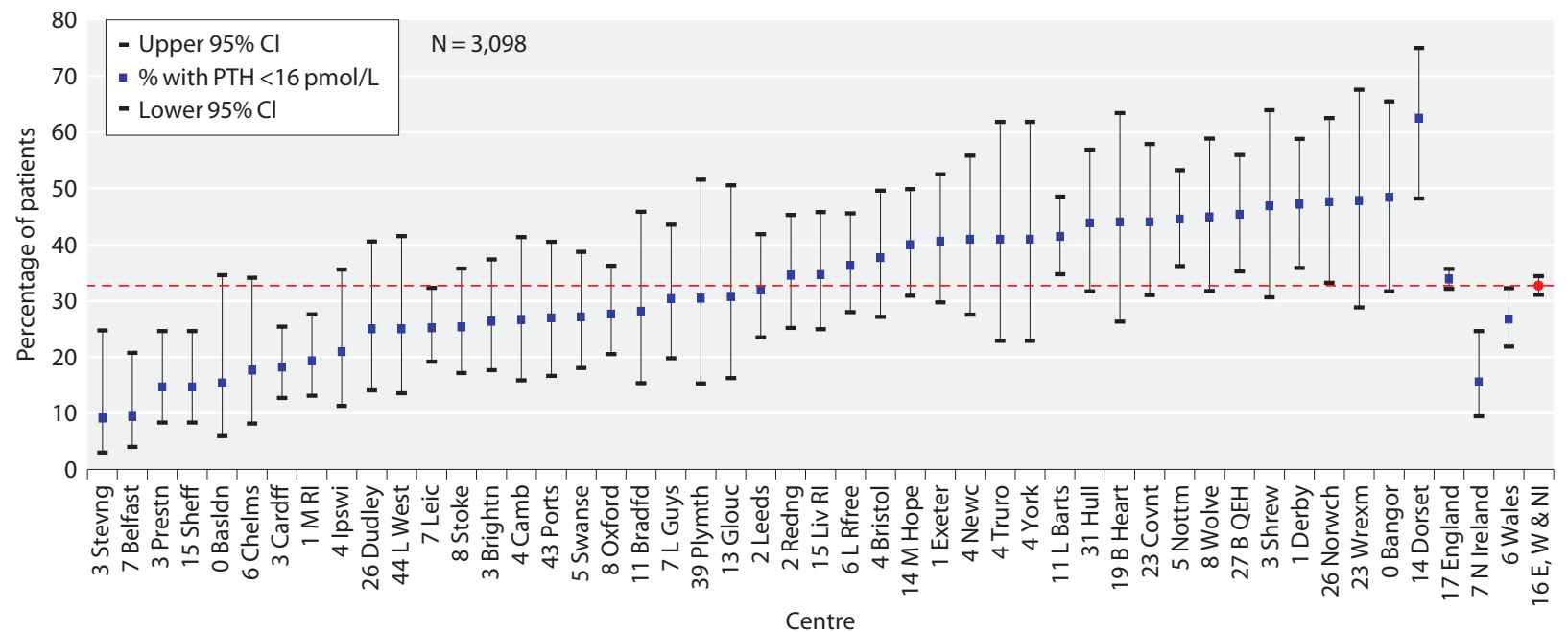

Fig. 10.35. Percentage of peritoneal dialysis patients with $\mathrm{PTH}<16 \mathrm{pmol} / \mathrm{L}$ by centre in 2007 


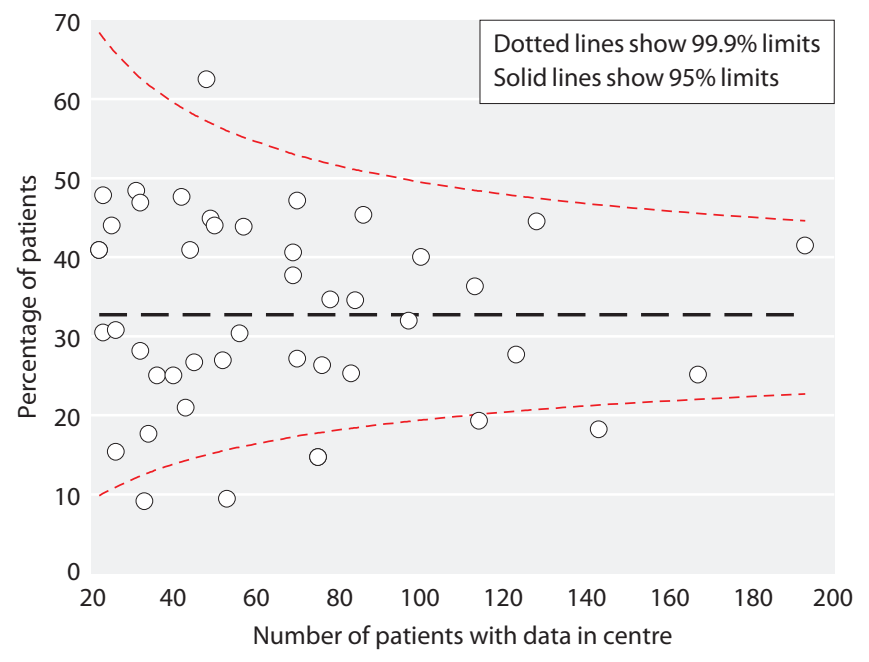

Fig. 10.36. Funnel plot of percentage of peritoneal dialysis patients with PTH $<16 \mathrm{pmol} / \mathrm{L}$ by centre in 2007

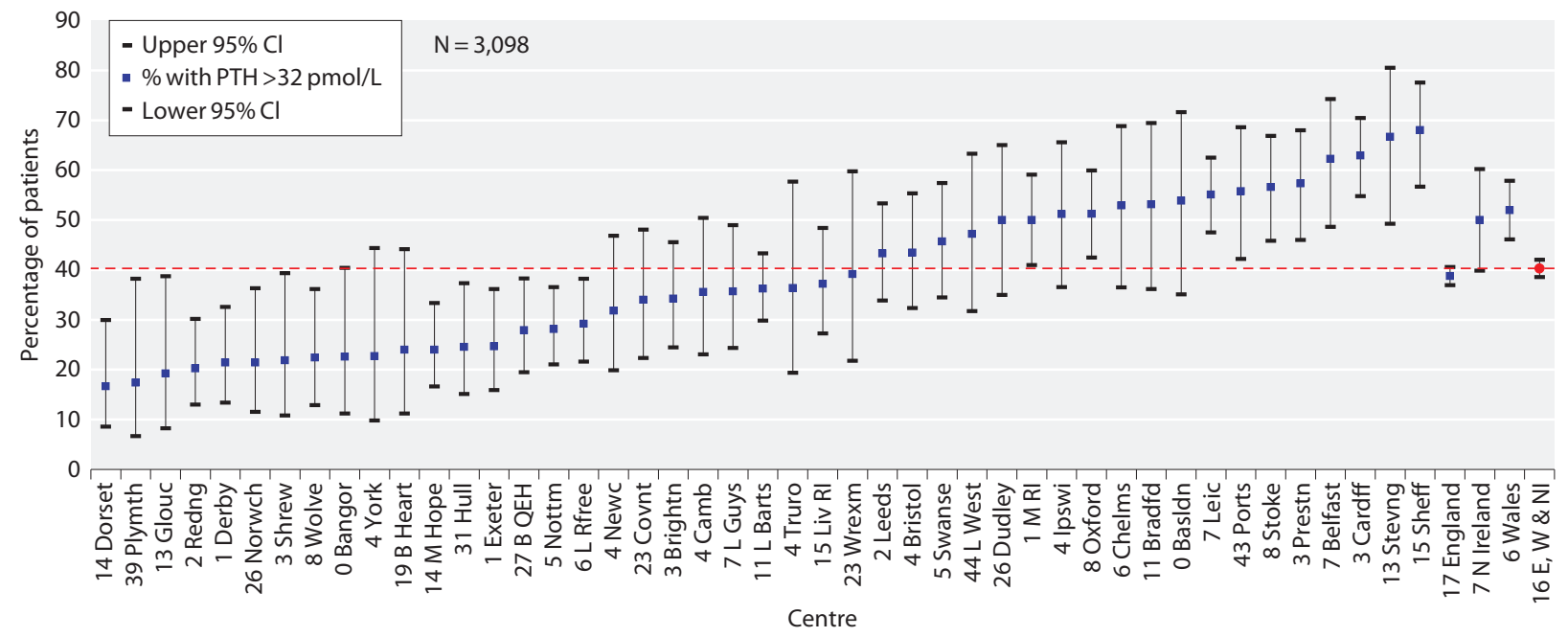

Fig. 10.37. Percentage of peritoneal dialysis patients with PTH $>32 \mathrm{pmol} / \mathrm{L}$ by centre in 2007

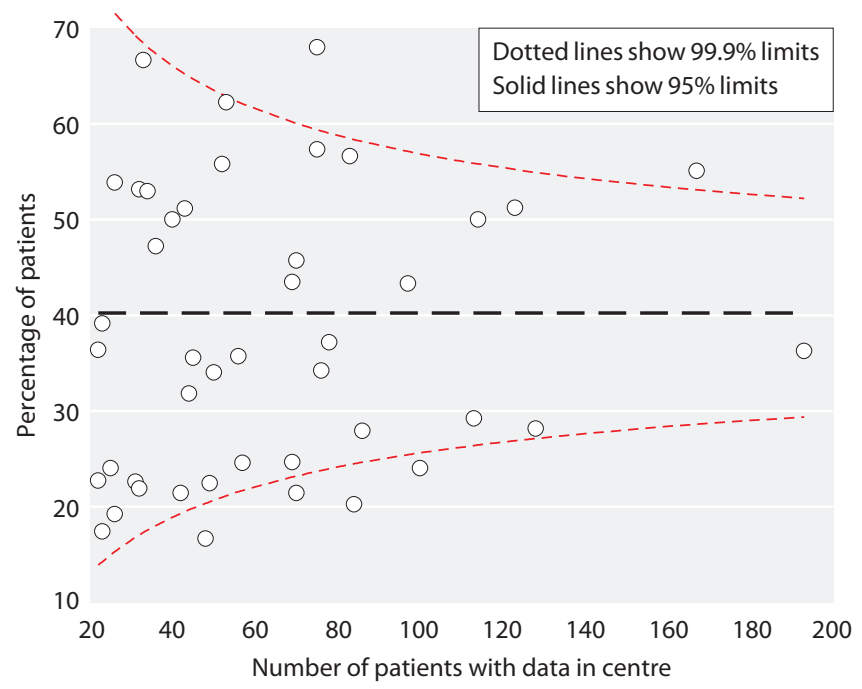

Fig. 10.38. Funnel plot of percentage of peritoneal dialysis patients with $\mathrm{PTH}>32 \mathrm{pmol} / \mathrm{L}$ by centre in 2007 
Discussion - Mineral and bone parameters

There were convincing observational data that hyperphosphataemia was associated with increased mortality in dialysis patients but the data linking calcium and parathyroid hormone to patient survival were less clear [7-11]. A recent cohort study has demonstrated that simultaneous achievement of all three audit measures does appear to be associated with better outcomes [12].

The UKRR has consistently demonstrated between centre variation in achievement of audit measures for bone and mineral parameters but little is understood about the causes of this 'centre effect'. The complexity of the clinical processes required to manage mineral and bone disorders is probably further confounded by case mix. Finally it is important to consider data quality and the potential for measurement bias particularly in light of the variability in assay methods across the UK for calcium and parathyroid hormone. However, detecting these centre level differences is an important step in understanding the factors associated with exceptional performance.

\section{Bicarbonate}

The 4th edition of the Renal Association Clinical Practice Guidelines state:
'For HD patients pre-dialysis serum bicarbonate concentrations measured with minimum delay after venepuncture and before a 'short gap' dialysis session should be between 20 and $26 \mathrm{mmol} / \mathrm{L}$ (Module 3a: Haemodialysis)

For PD patients, Plasma bicarbonate should be maintained within the normal range.' (Module 3b: Peritoneal dialysis) [1]

\section{Results and discussion}

Bicarbonate data were $82 \%$ complete for HD patients and $81 \%$ complete for PD patients (tables 10.14 and 10.16). Seventy one percent (CI 70-72\%) of HD patients and $50 \%$ (CI 49-52\%) of PD patients achieved the audit measure for bicarbonate and there was inter-centre variation for both HD and PD (tables 10.15 and 10.17, figures 10.39 and 10.40). There was even greater between centre variation in the proportion of patients with bicarbonate values above and below the specified range for the audit measure (tables 10.15 and 10.17). The UKRR previously conducted a limited survey into the possible underlying causes of this variation. The study predominantly looked at measures of sample processing and of dialysis treatment. It did not adjust for case mix

Table 10.14. Summary statistics for bicarbonate in haemodialysis patients in 2007

\begin{tabular}{|c|c|c|c|c|c|c|c|}
\hline Centre & $\begin{array}{c}\% \\
\text { completeness }\end{array}$ & $\begin{array}{c}\text { Number of } \\
\text { patients } \\
\text { with data }\end{array}$ & Mean & SD & Median & $\begin{array}{c}\text { Lower } \\
\text { quartile }\end{array}$ & $\begin{array}{c}\text { Upper } \\
\text { quartile }\end{array}$ \\
\hline B Heart & 93 & 317 & 25 & 2.7 & 25 & 23 & 26 \\
\hline $\mathrm{B} \mathrm{QEH}$ & 93 & 630 & 24 & 3.4 & 24 & 22 & 26 \\
\hline Bangor & 96 & 53 & 23 & 2.3 & 23 & 22 & 24 \\
\hline Bradfd & 99 & 157 & 22 & 2.9 & 22 & 20 & 24 \\
\hline Brightn & 100 & 274 & 23 & 2.7 & 23 & 21 & 25 \\
\hline Bristol & 100 & 398 & 23 & 2.5 & 23 & 22 & 25 \\
\hline Camb & 52 & 169 & 24 & 3.4 & 24 & 22 & 26 \\
\hline Cardff & 76 & 346 & 20 & 3.4 & 20 & 18 & 23 \\
\hline Carlis & 95 & 77 & 23 & 2.2 & 23 & 22 & 24 \\
\hline Carsh & 83 & 436 & 26 & 4.0 & 26 & 23 & 29 \\
\hline Derry & 100 & 41 & 21 & 1.9 & 22 & 20 & 22 \\
\hline Donc & 100 & 54 & 22 & 2.7 & 22 & 21 & 24 \\
\hline Dorset & 100 & 137 & 26 & 3.1 & 26 & 24 & 27 \\
\hline Dudley & 88 & 95 & 25 & 3.3 & 25 & 23 & 27 \\
\hline Exeter & 99 & 258 & 22 & 2.5 & 23 & 21 & 24 \\
\hline Glouc & 100 & 162 & 25 & 2.4 & 25 & 24 & 26 \\
\hline Hull & 97 & 278 & 22 & 2.9 & 22 & 20 & 24 \\
\hline Ipswi & 100 & 86 & 21 & 3.0 & 21 & 18 & 23 \\
\hline L Barts & 100 & 540 & 24 & 2.9 & 24 & 22 & 26 \\
\hline
\end{tabular}


Table 10.14. Continued

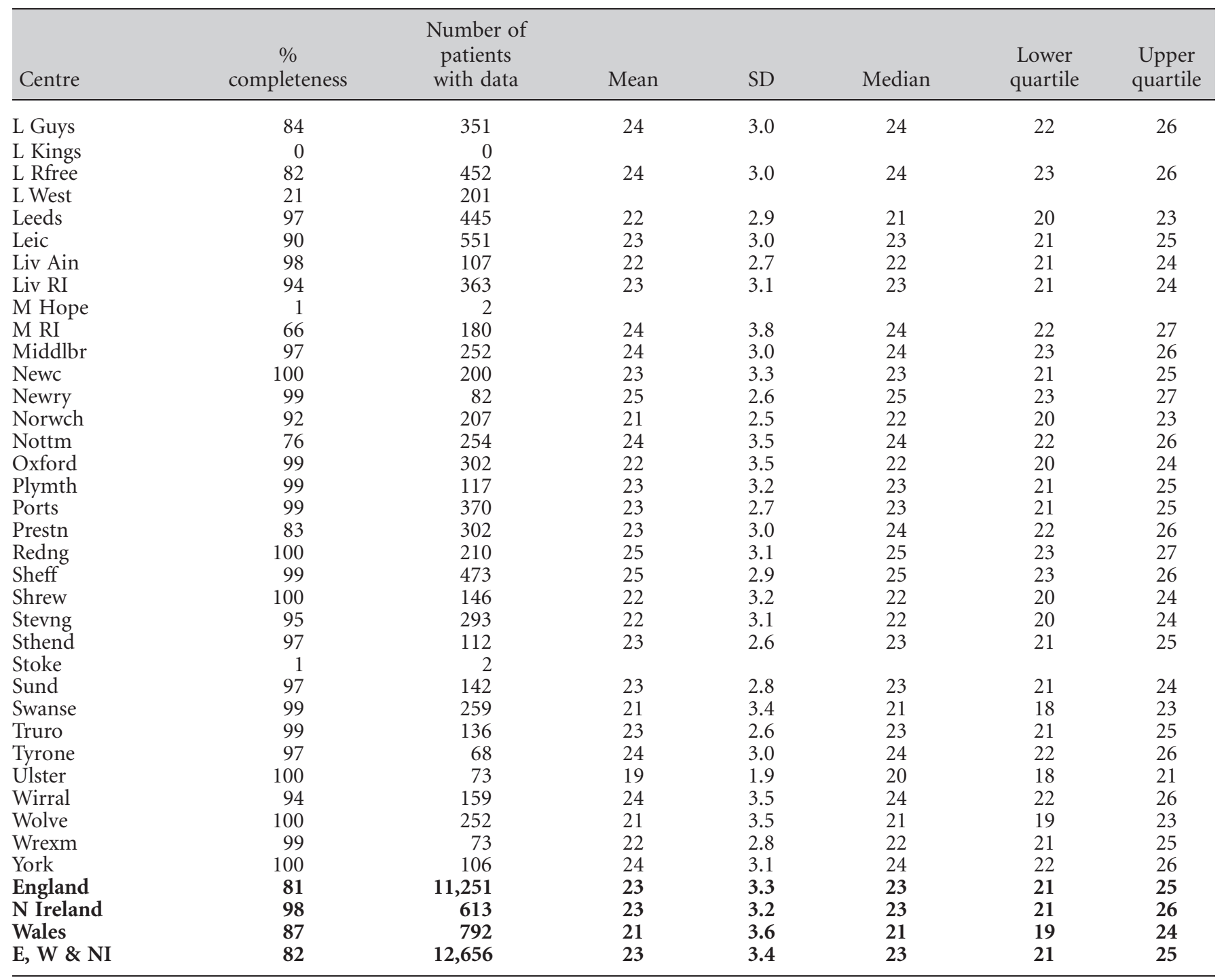

Blank cells denote centres excluded from analyses due to low patient numbers or poor data completeness

Table 10.15. Percentage of haemodialysis patients within, below and above the range for bicarbonate (20-26 mmol/L) in 2007

\begin{tabular}{|c|c|c|c|c|c|c|c|c|c|c|}
\hline Centre & $\mathrm{N}$ & $\begin{array}{c}\% \text { bicarb } \\
20-26 \\
\mathrm{mmol} / \mathrm{L}\end{array}$ & $\begin{array}{l}\text { Lower } \\
95 \% \text { CI }\end{array}$ & $\begin{array}{c}\text { Upper } \\
95 \% \text { CI }\end{array}$ & $\begin{array}{c}\% \text { bicarb } \\
<20 \\
\mathrm{mmol} / \mathrm{L}\end{array}$ & $\begin{array}{l}\text { Lower } \\
95 \% \text { CI }\end{array}$ & $\begin{array}{l}\text { Upper } \\
95 \% \text { CI }\end{array}$ & $\begin{array}{c}\% \text { bicarb } \\
>26 \\
\mathrm{mmol} / \mathrm{L}\end{array}$ & $\begin{array}{l}\text { Lower } \\
95 \% \text { CI }\end{array}$ & $\begin{array}{l}\text { Upper } \\
95 \% \text { CI }\end{array}$ \\
\hline B Heart & 317 & 66.9 & 61.5 & 71.8 & 5.4 & 3.4 & 8.5 & 27.8 & 23.1 & 33.0 \\
\hline B QEH & 630 & 69.5 & 65.8 & 73.0 & 9.5 & 7.5 & 12.1 & 21.0 & 18.0 & 24.3 \\
\hline Bangor & 53 & 77.4 & 64.2 & 86.7 & 9.4 & 4.0 & 20.7 & 13.2 & 6.4 & 25.2 \\
\hline Bradfd & 157 & 80.3 & 73.3 & 85.8 & 12.7 & 8.4 & 18.9 & 7.0 & 3.9 & 12.2 \\
\hline Brightn & 274 & 77.4 & 72.0 & 81.9 & 11.0 & 7.8 & 15.2 & 11.7 & 8.4 & 16.1 \\
\hline Bristol & 398 & 84.2 & 80.3 & 87.4 & 7.5 & 5.3 & 10.6 & 8.3 & 6.0 & 11.4 \\
\hline Camb & 169 & 66.9 & 59.4 & 73.5 & 8.9 & 5.4 & 14.2 & 24.3 & 18.4 & 31.3 \\
\hline
\end{tabular}


Table 10.15. Continued

\begin{tabular}{|c|c|c|c|c|c|c|c|c|c|c|}
\hline Centre & $\mathrm{N}$ & $\begin{array}{c}\% \text { bicarb } \\
20-26 \\
\mathrm{mmol} / \mathrm{L}\end{array}$ & $\begin{array}{l}\text { Lower } \\
95 \% \text { CI }\end{array}$ & $\begin{array}{c}\text { Upper } \\
95 \% \text { CI }\end{array}$ & $\begin{array}{c}\% \text { bicarb } \\
<20 \\
\mathrm{mmol} / \mathrm{L}\end{array}$ & $\begin{array}{l}\text { Lower } \\
95 \% \text { CI }\end{array}$ & $\begin{array}{c}\text { Upper } \\
95 \% \text { CI }\end{array}$ & $\begin{array}{c}\% \text { bicarb } \\
>26 \\
\mathrm{mmol} / \mathrm{L}\end{array}$ & $\begin{array}{l}\text { Lower } \\
95 \% \text { CI }\end{array}$ & $\begin{array}{l}\text { Upper } \\
95 \% \text { CI }\end{array}$ \\
\hline Cardff & 346 & 50.0 & 44.8 & 55.3 & 45.7 & 40.5 & 50.9 & 4.3 & 2.6 & 7.1 \\
\hline Carlis & 77 & 85.7 & 76.0 & 91.9 & 6.5 & 2.7 & 14.7 & 7.8 & 3.5 & 16.3 \\
\hline Carsh & 436 & 51.4 & 46.7 & 56.0 & 3.4 & 2.1 & 5.6 & 45.2 & 40.6 & 49.9 \\
\hline Chelms & 94 & 62.8 & 52.6 & 71.9 & 3.2 & 1.0 & 9.4 & 34.0 & 25.2 & 44.2 \\
\hline Clwyd & 61 & 73.8 & 61.4 & 83.3 & 3.3 & 0.8 & 12.2 & 23.0 & 14.1 & 35.1 \\
\hline Derby & 172 & 77.3 & 70.5 & 83.0 & 10.5 & 6.7 & 16.0 & 12.2 & 8.1 & 18.0 \\
\hline Derry & 41 & 78.1 & 62.9 & 88.2 & 22.0 & 11.8 & 37.1 & 0.0 & 0.0 & 0.0 \\
\hline Donc & 54 & 79.6 & 66.8 & 88.4 & 11.1 & 5.1 & 22.6 & 9.3 & 3.9 & 20.4 \\
\hline Dorset & 137 & 59.9 & 51.4 & 67.7 & 3.7 & 1.5 & 8.5 & 36.5 & 28.9 & 44.9 \\
\hline Dudley & 95 & 60.0 & 49.9 & 69.3 & 2.1 & 0.5 & 8.0 & 37.9 & 28.7 & 48.0 \\
\hline Exeter & 258 & 87.6 & 83.0 & 91.1 & 10.5 & 7.3 & 14.8 & 1.9 & 0.8 & 4.6 \\
\hline Glouc & 162 & 75.9 & 68.8 & 81.9 & 1.2 & 0.3 & 4.8 & 22.8 & 17.0 & 29.9 \\
\hline Hull & 278 & 76.6 & 71.3 & 81.2 & 20.5 & 16.2 & 25.7 & 2.9 & 1.5 & 5.7 \\
\hline Ipswi & 86 & 59.3 & 48.7 & 69.1 & 38.4 & 28.7 & 49.0 & 2.3 & 0.6 & 8.8 \\
\hline L Barts & 540 & 76.7 & 72.9 & 80.0 & 7.0 & 5.2 & 9.5 & 16.3 & 13.4 & 19.7 \\
\hline L Guys & 351 & 75.5 & 70.7 & 79.7 & 8.3 & 5.8 & 11.6 & 16.2 & 12.7 & 20.5 \\
\hline L Rfree & 452 & 70.6 & 66.2 & 74.6 & 5.5 & 3.8 & 8.1 & 23.9 & 20.2 & 28.0 \\
\hline Leeds & 445 & 74.6 & 70.4 & 78.4 & 20.0 & 16.5 & 24.0 & 5.4 & 3.6 & 7.9 \\
\hline Leic & 551 & 74.4 & 70.6 & 77.9 & 12.0 & 9.5 & 15.0 & 13.6 & 11.0 & 16.7 \\
\hline Liv Ain & 107 & 76.6 & 67.7 & 83.7 & 14.0 & 8.6 & 22.0 & 9.4 & 5.1 & 16.5 \\
\hline Liv RI & 363 & 75.8 & 71.1 & 79.9 & 13.8 & 10.6 & 17.7 & 10.5 & 7.7 & 14.1 \\
\hline M RI & 180 & 63.9 & 56.6 & 70.6 & 8.3 & 5.1 & 13.4 & 27.8 & 21.7 & 34.8 \\
\hline Middlbr & 252 & 75.4 & 69.7 & 80.3 & 4.4 & 2.4 & 7.7 & 20.2 & 15.7 & 25.7 \\
\hline Newc & 200 & 70.0 & 63.3 & 76.0 & 14.0 & 9.8 & 19.5 & 16.0 & 11.5 & 21.8 \\
\hline Newry & 82 & 64.6 & 53.8 & 74.2 & 2.4 & 0.6 & 9.2 & 32.9 & 23.7 & 43.8 \\
\hline Norwch & 207 & 77.3 & 71.1 & 82.5 & 21.3 & 16.2 & 27.4 & 1.5 & 0.5 & 4.4 \\
\hline Nottm & 254 & 71.3 & 65.4 & 76.5 & 8.7 & 5.8 & 12.8 & 20.1 & 15.6 & 25.5 \\
\hline Oxford & 302 & 66.6 & 61.0 & 71.7 & 23.2 & 18.8 & 28.3 & 10.3 & 7.3 & 14.2 \\
\hline Plymth & 117 & 72.7 & 63.9 & 80.0 & 17.1 & 11.3 & 25.0 & 10.3 & 5.9 & 17.2 \\
\hline Ports & 370 & 78.7 & 74.2 & 82.5 & 11.9 & 9.0 & 15.6 & 9.5 & 6.9 & 12.9 \\
\hline Prestn & 302 & 72.2 & 66.9 & 77.0 & 10.9 & 7.9 & 15.0 & 16.9 & 13.1 & 21.5 \\
\hline Redng & 210 & 69.5 & 63.0 & 75.4 & 4.3 & 2.2 & 8.0 & 26.2 & 20.7 & 32.6 \\
\hline Sheff & 473 & 72.5 & 68.3 & 76.4 & 3.2 & 1.9 & 5.2 & 24.3 & 20.7 & 28.4 \\
\hline Shrew & 146 & 70.6 & 62.7 & 77.4 & 23.3 & 17.1 & 30.8 & 6.2 & 3.2 & 11.4 \\
\hline Stevng & 293 & 73.4 & 68.0 & 78.1 & 19.5 & 15.3 & 24.4 & 7.2 & 4.7 & 10.7 \\
\hline Sthend & 112 & 81.3 & 73.0 & 87.4 & 9.8 & 5.5 & 16.9 & 8.9 & 4.9 & 15.8 \\
\hline Sund & 142 & 82.4 & 75.2 & 87.8 & 11.3 & 7.0 & 17.6 & 6.3 & 3.3 & 11.7 \\
\hline Swanse & 259 & 56.8 & 50.7 & 62.7 & 38.6 & 32.9 & 44.7 & 4.6 & 2.7 & 8.0 \\
\hline Truro & 136 & 84.6 & 77.5 & 89.7 & 6.6 & 3.5 & 12.2 & 8.8 & 5.1 & 14.9 \\
\hline Tyrone & 68 & 72.1 & 60.3 & 81.4 & 8.8 & 4.0 & 18.3 & 19.1 & 11.4 & 30.2 \\
\hline Ulster & 73 & 54.8 & 43.3 & 65.8 & 45.2 & 34.2 & 56.7 & 0.0 & 0.0 & 0.0 \\
\hline Wirral & 159 & 69.2 & 61.6 & 75.9 & 9.4 & 5.8 & 15.1 & 21.4 & 15.7 & 28.4 \\
\hline Wolve & 252 & 59.5 & 53.4 & 65.4 & 35.3 & 29.7 & 41.4 & 5.2 & 3.0 & 8.7 \\
\hline Wrexm & 73 & 84.9 & 74.8 & 91.5 & 9.6 & 4.6 & 18.8 & 5.5 & 2.1 & 13.7 \\
\hline York & 106 & 73.6 & 64.4 & 81.1 & 5.7 & 2.6 & 12.0 & 20.8 & 14.1 & 29.5 \\
\hline England & 11,251 & 72.1 & 71.2 & 72.9 & 12.1 & 11.5 & 12.7 & 15.9 & 15.2 & 16.6 \\
\hline $\mathrm{N}$ Ireland & 613 & 71.5 & 67.8 & 74.9 & 11.8 & 9.4 & 14.5 & 16.8 & 14.1 & 20.0 \\
\hline Wales & 792 & 59.1 & 55.6 & 62.5 & 34.3 & 31.1 & 37.7 & 6.6 & 5.0 & 8.5 \\
\hline E, W \& NI & 12,656 & 71.2 & 70.4 & 72.0 & 13.4 & 12.9 & 14.1 & 15.3 & 14.7 & 16.0 \\
\hline
\end{tabular}




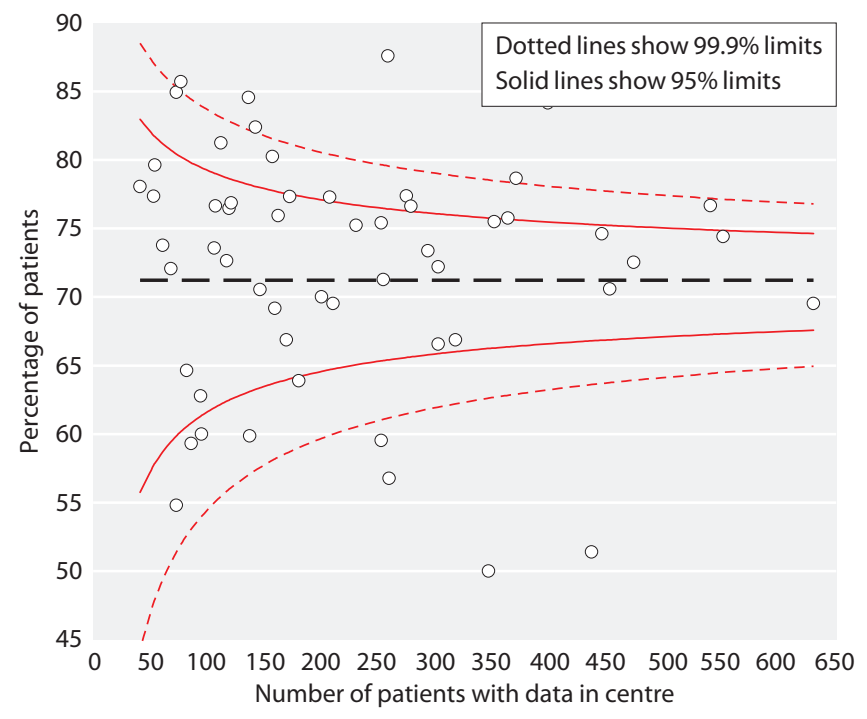

Fig. 10.39. Funnel plot of percentage of haemodialysis patients with bicarbonate $20-26 \mathrm{mmol} / \mathrm{L}$ by centre in 2007

Table 10.16. Summary statistics for serum bicarbonate in peritoneal dialysis patients in 2007

\begin{tabular}{|c|c|c|c|c|c|c|c|}
\hline Centre & $\begin{array}{c}\% \\
\text { completeness }\end{array}$ & $\begin{array}{l}\text { Number of } \\
\text { patients } \\
\text { with data }\end{array}$ & Mean & SD & Median & $\begin{array}{l}\text { Lower } \\
\text { quartile }\end{array}$ & $\begin{array}{l}\text { Upper } \\
\text { quartile }\end{array}$ \\
\hline Antrim & 94 & 15 & & & & & \\
\hline B Heart & 97 & 30 & 26 & 2.44 & 26 & 25 & 27 \\
\hline B QEH & 81 & 95 & 26 & 3.14 & 26 & 24 & 28 \\
\hline Bangor & 97 & 30 & 26 & 3.11 & 26 & 23 & 29 \\
\hline Basldn & 100 & 26 & 26 & 2.96 & 26 & 24 & 27 \\
\hline Belfast & 96 & 55 & 27 & 3.21 & 27 & 24 & 28 \\
\hline Bradfd & 100 & 36 & 26 & 2.75 & 26 & 24 & 28 \\
\hline Brightn & 97 & 76 & 24 & 2.81 & 24 & 23 & 25 \\
\hline Bristol & 100 & 72 & 25 & 2.78 & 26 & 24 & 27 \\
\hline Camb & 100 & 47 & 28 & 4.38 & 28 & 25 & 32 \\
\hline Cardff & 97 & 142 & 22 & 3.54 & 22 & 20 & 24 \\
\hline Carlis & 100 & 11 & & & & & \\
\hline Carsh & 94 & 106 & 31 & 3.64 & 32 & 29 & 34 \\
\hline Chelms & 97 & 35 & 28 & 2.46 & 28 & 26 & 30 \\
\hline Clwyd & 92 & 12 & & & & & \\
\hline Covnt & 54 & 35 & 25 & 2.59 & 25 & 24 & 27 \\
\hline Derby & 100 & 71 & 27 & 3.57 & 27 & 24 & 29 \\
\hline Derry & 100 & 4 & & & & & \\
\hline Donc & 39 & 13 & & & & & \\
\hline Dorset & 98 & 55 & 25 & 2.91 & 26 & 23 & 27 \\
\hline Dudley & 91 & 49 & 26 & 3.00 & 26 & 24 & 28 \\
\hline Exeter & 100 & 70 & 24 & 3.36 & 24 & 22 & 27 \\
\hline Glouc & 100 & 30 & 27 & 2.37 & 27 & 26 & 28 \\
\hline Hull & 95 & 79 & 26 & 2.77 & 26 & 24 & 28 \\
\hline Ipswi & 96 & 43 & 25 & 2.77 & 25 & 22 & 27 \\
\hline L Barts & 100 & 217 & 27 & 3.01 & 26 & 25 & 28 \\
\hline L Guys & 97 & 58 & 24 & 2.87 & 23 & 22 & 26 \\
\hline L Kings & 1 & 1 & & & & & \\
\hline L Rfree & 95 & 114 & 26 & 3.36 & 26 & 24 & 28 \\
\hline L West & 0 & 0 & & & & & \\
\hline Leeds & 99 & 98 & 25 & 3.07 & 25 & 23 & 28 \\
\hline Leic & 92 & 166 & 25 & 3.31 & 26 & 23 & 28 \\
\hline Liv RI & 92 & 85 & 24 & 3.04 & 24 & 22 & 26 \\
\hline
\end{tabular}


Table 10.16. Continued

\begin{tabular}{|c|c|c|c|c|c|c|c|}
\hline Centre & $\begin{array}{c}\% \\
\text { completeness }\end{array}$ & $\begin{array}{c}\text { Number of } \\
\text { patients } \\
\text { with data }\end{array}$ & Mean & SD & Median & $\begin{array}{c}\text { Lower } \\
\text { quartile }\end{array}$ & $\begin{array}{l}\text { Upper } \\
\text { quartile }\end{array}$ \\
\hline M Hope & 0 & 0 & & & & & \\
\hline M RI & 100 & 115 & 26 & 2.69 & 26 & 24 & 27 \\
\hline Middlbr & 92 & 23 & 28 & 2.74 & 27 & 26 & 29 \\
\hline Norwch & 96 & 55 & 21 & 2.35 & 21 & 20 & 23 \\
\hline Nottm & 18 & 24 & & & & & \\
\hline Oxford & 77 & 103 & 26 & 3.65 & 25 & 23 & 28 \\
\hline Plymth & 100 & 38 & 25 & 4.02 & 25 & 23 & 27 \\
\hline Ports & 68 & 63 & 25 & 2.78 & 25 & 24 & 27 \\
\hline Prestn & 83 & 64 & 26 & 3.13 & 25 & 23 & 28 \\
\hline Sthend & 94 & 17 & & & & & \\
\hline Stoke & 0 & 0 & & & & & \\
\hline Sund & 100 & 10 & & & & & \\
\hline Swanse & 96 & 71 & 25 & 3.78 & 25 & 23 & 27 \\
\hline Truro & 96 & 22 & 26 & 3.46 & 27 & 26 & 29 \\
\hline Tyrone & 100 & 5 & & & & & \\
\hline Ulster & 100 & 2 & & & & & \\
\hline Wirral & 68 & 19 & & & & & \\
\hline Wolve & 98 & 52 & 26 & 2.92 & 27 & 24 & 28 \\
\hline Wrexm & 90 & 27 & 24 & 2.47 & 25 & 23 & 27 \\
\hline York & 100 & 23 & 26 & 2.92 & 26 & 23 & 28 \\
\hline England & 80 & 2,635 & 26 & 3.45 & 26 & 24 & 28 \\
\hline
\end{tabular}

Blank cells denote centres excluded from analyses due to low patient numbers or poor data completeness n/a not applicable

Table 10.17. Percentage of peritoneal dialysis patients within, below and above the range for bicarbonate (25-29 $\mathrm{mmol} / \mathrm{L})$ in 2007

\begin{tabular}{|c|c|c|c|c|c|c|c|c|c|c|}
\hline Centre & $\mathrm{N}$ & $\begin{array}{c}\text { \% bicarb } \\
25-29 \\
\mathrm{mmol} / \mathrm{L}\end{array}$ & $\begin{array}{l}\text { Lower } \\
95 \% \text { CI }\end{array}$ & $\begin{array}{c}\text { Upper } \\
95 \% \text { CI }\end{array}$ & $\begin{array}{c}\% \text { bicarb } \\
<25 \\
\mathrm{mmol} / \mathrm{L}\end{array}$ & $\begin{array}{l}\text { Lower } \\
95 \% \text { CI }\end{array}$ & $\begin{array}{c}\text { Upper } \\
95 \% \text { CI }\end{array}$ & $\begin{array}{c}\% \text { bicarb } \\
>29 \\
\mathrm{mmol} / \mathrm{L}\end{array}$ & $\begin{array}{l}\text { Lower } \\
95 \% \text { CI }\end{array}$ & $\begin{array}{l}\text { Upper } \\
95 \% \text { CI }\end{array}$ \\
\hline B Heart & 30 & 56.7 & 38.8 & 72.9 & 26.7 & 13.9 & 45.0 & 16.7 & 7.1 & 34.3 \\
\hline B QEH & 95 & 50.5 & 40.6 & 60.4 & 37.9 & 28.7 & 48.0 & 11.6 & 6.5 & 19.7 \\
\hline Bangor & 30 & 46.7 & 29.9 & 64.2 & 43.3 & 27.1 & 61.2 & 10.0 & 3.3 & 26.8 \\
\hline Basldn & 26 & 57.7 & 38.5 & 74.8 & 26.9 & 13.4 & 46.7 & 15.4 & 5.9 & 34.5 \\
\hline Belfast & 55 & 58.2 & 44.9 & 70.4 & 25.5 & 15.7 & 38.5 & 16.4 & 8.7 & 28.6 \\
\hline Bradfd & 36 & 69.4 & 52.8 & 82.2 & 27.8 & 15.7 & 44.4 & 2.8 & 0.4 & 17.3 \\
\hline Brightn & 76 & 25.0 & 16.6 & 35.9 & 68.4 & 57.2 & 77.9 & 6.6 & 2.8 & 14.9 \\
\hline Bristol & 72 & 62.5 & 50.8 & 72.9 & 34.7 & 24.7 & 46.4 & 2.8 & 0.7 & 10.4 \\
\hline Camb & 47 & 48.9 & 35.1 & 62.9 & 17.0 & 8.8 & 30.5 & 34.0 & 22.0 & 48.6 \\
\hline Cardff & 142 & 21.8 & 15.8 & 29.4 & 76.1 & 68.4 & 82.4 & 2.1 & 0.7 & 6.3 \\
\hline Carsh & 106 & 25.5 & 18.1 & 34.6 & 4.7 & 2.0 & 10.8 & 69.8 & 60.4 & 77.8 \\
\hline Chelms & 35 & 62.9 & 46.0 & 77.1 & 8.6 & 2.8 & 23.4 & 28.6 & 16.1 & 45.4 \\
\hline Covnt & 35 & 57.1 & 40.6 & 72.3 & 40.0 & 25.3 & 56.7 & 2.9 & 0.4 & 17.7 \\
\hline Derby & 71 & 54.9 & 43.3 & 66.1 & 28.2 & 19.0 & 39.7 & 16.9 & 9.9 & 27.5 \\
\hline
\end{tabular}


Table 10.17. Continued

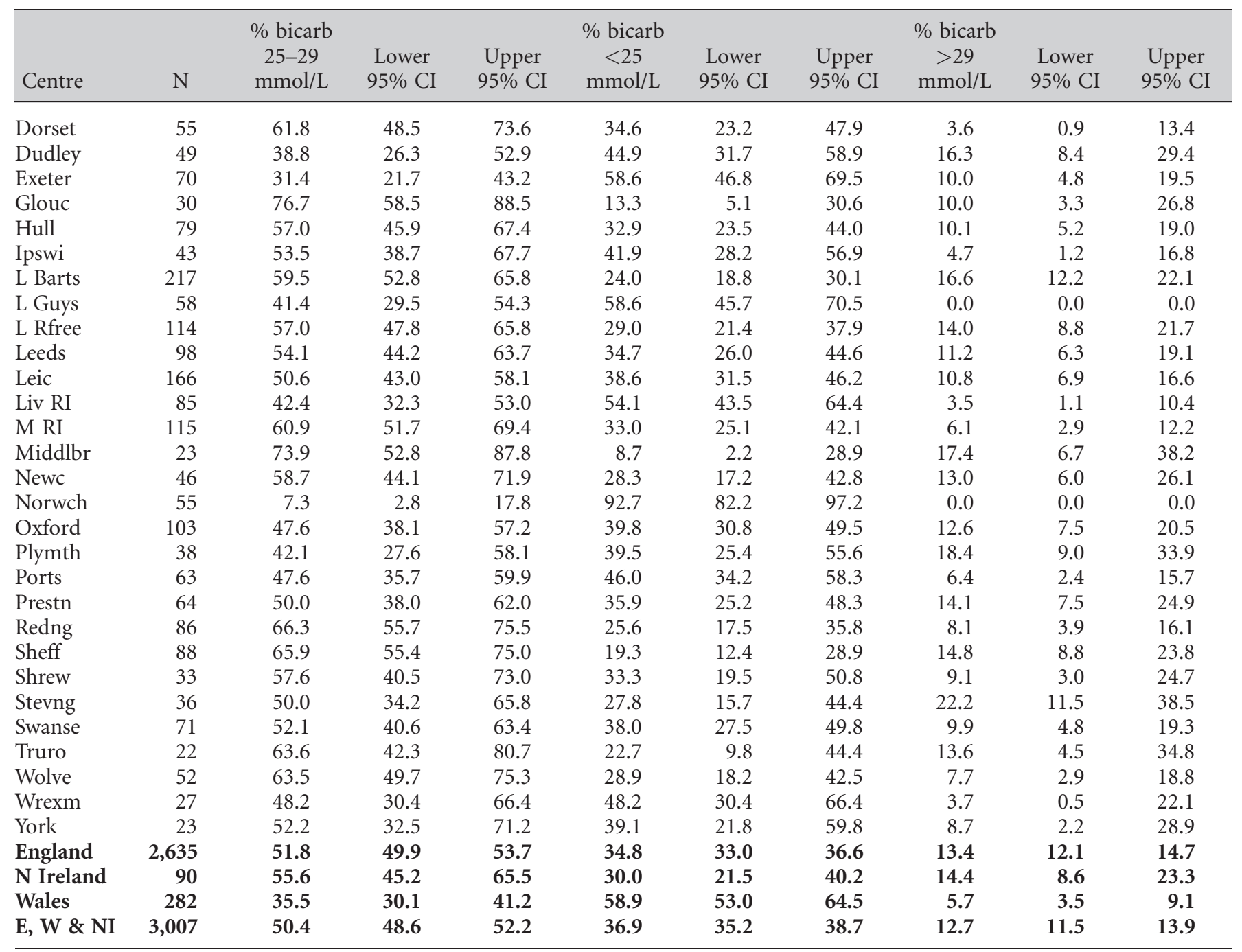

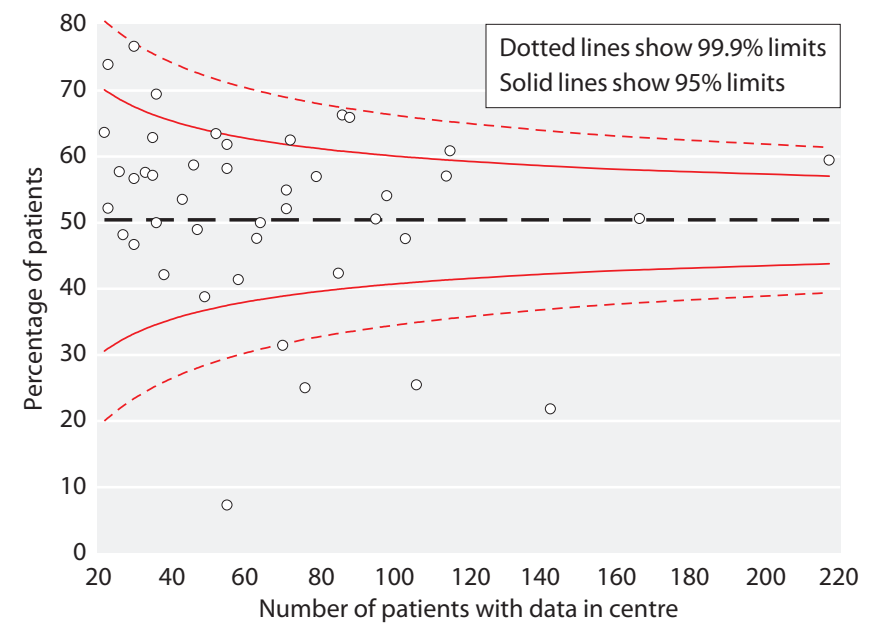

Fig. 10.40. Funnel plot of percentage of peritoneal dialysis patients with bicarbonate $25-29 \mathrm{mmol} / \mathrm{L}$ by centre in 2007 
and was unable to detect any significant differences between centres. However, it was possible that there may be unmeasured processes including dialysis and oral bicarbonate prescription that might account for the variation observed [13].

\section{Total cholesterol}

There is no audit standard for total cholesterol in the 4th edition of the Renal Association Clinical Practice Guidelines. Current guidance on lipid management states:

'Three hydroxy-3 methylglutaryl-Co-enzyme A reductase inhibitors (statins) should be considered for primary prevention in all CKD including dialysis patients with a 10-year risk of cardiovascular disease, calculated as $>20 \%$ according to the Joint British Societies' Guidelines (JBS 2), despite the fact that these calculations have not been validated in patients with renal disease. The target total cholesterol should be $<4 \mathrm{mmol} / \mathrm{l}$ or a $25 \%$ reduction from baseline, and a fasting low density lipoprotein (LDL)-cholesterol of $<2 \mathrm{mmol} / \mathrm{l}$ or a $30 \%$ reduction from baseline, should be achieved, whichever is the greatest reduction in all patients (Evidence in CKD 1-3, Good Practice in CKD 4-5 and dialysis patients). Statins should not be withdrawn from patients in whom they were previously indicated and should continue to be prescribed when such patients start renal replacement therapy (RRT) or change modality. (Good Practice).' (Module 2: Complications) [1]

\section{Results and discussion}

Total cholesterol data were $80 \%$ complete for HD patients and $82 \%$ complete for PD patients. As there were no specific audit measures for total cholesterol, summary data were presented for each dialysis centre (tables 10.18 and 10.19, figures 10.41 and 10.42). There were a

Table 10.18. Summary statistics for total cholesterol in haemodialysis patients in 2007

\begin{tabular}{|c|c|c|c|c|c|c|c|}
\hline Centre & $\begin{array}{c}\% \\
\text { completeness }\end{array}$ & $\begin{array}{c}\text { Number of } \\
\text { patients } \\
\text { with data }\end{array}$ & Mean & $\mathrm{SD}$ & Median & $\begin{array}{c}\text { Lower } \\
\text { quartile }\end{array}$ & $\begin{array}{l}\text { Upper } \\
\text { quartile }\end{array}$ \\
\hline Antrim & 99 & 122 & 3.7 & 1.0 & 3.6 & 3.1 & 4.1 \\
\hline B Heart & 49 & 174 & & & & & \\
\hline B QEH & 91 & 630 & 3.9 & 1.1 & 3.7 & 3.2 & 4.4 \\
\hline Bangor & 83 & 50 & 3.9 & 1.1 & 3.8 & 3.1 & 4.7 \\
\hline Basldn & 98 & 121 & 4.1 & 1.0 & 4.0 & 3.5 & 4.7 \\
\hline Belfast & 85 & 210 & 3.9 & 1.1 & 3.8 & 3.1 & 4.4 \\
\hline Bradfd & 78 & 124 & 4.2 & 1.0 & 4.1 & 3.5 & 4.9 \\
\hline Brightn & 24 & 72 & & & & & \\
\hline Bristol & 93 & 397 & 4.1 & 1.1 & 4.0 & 3.3 & 4.7 \\
\hline Camb & 51 & 169 & 3.7 & 1.0 & 3.5 & 3.1 & 4.2 \\
\hline Cardff & 89 & 405 & 3.9 & 1.0 & 3.8 & 3.1 & 4.5 \\
\hline Carlis & 94 & 76 & 4.1 & 1.0 & 4.1 & 3.4 & 4.7 \\
\hline Carsh & 64 & 334 & 4.2 & 1.1 & 4.1 & 3.4 & 4.8 \\
\hline Chelms & 98 & 92 & 3.5 & 1.0 & 3.4 & 2.8 & 4.3 \\
\hline Clwyd & 31 & 21 & & & & & \\
\hline Covnt & 0 & 0 & & & & & \\
\hline Derby & 90 & 165 & 3.9 & 1.1 & 3.7 & 3.1 & 4.4 \\
\hline Derry & 100 & 41 & 3.9 & 0.9 & 3.7 & 3.4 & 4.2 \\
\hline Donc & 83 & 45 & 3.8 & 0.8 & 3.7 & 3.3 & 4.1 \\
\hline Dorset & 91 & 126 & 4.1 & 1.0 & 4.0 & 3.4 & 4.7 \\
\hline Dudley & 97 & 107 & 3.7 & 1.0 & 3.5 & 3.0 & 4.4 \\
\hline Exeter & 90 & 235 & 4.1 & 1.2 & 4.0 & 3.2 & 4.7 \\
\hline Glouc & 83 & 135 & 4.0 & 1.0 & 3.9 & 3.2 & 4.4 \\
\hline Hull & 86 & 257 & 4.2 & 1.1 & 4.0 & 3.5 & 4.9 \\
\hline Ipswi & 89 & 80 & 3.9 & 1.1 & 3.8 & 3.1 & 4.7 \\
\hline L Barts & 99 & 548 & 3.9 & 1.0 & 3.7 & 3.1 & 4.5 \\
\hline L Guys & 96 & 425 & 3.8 & 1.1 & 3.7 & 3.1 & 4.3 \\
\hline L Kings & 95 & 293 & 3.9 & 0.9 & 3.8 & 3.3 & 4.4 \\
\hline L Rfree & 84 & 478 & 3.9 & 1.0 & 3.8 & 3.2 & 4.4 \\
\hline L West & 78 & 768 & 4.4 & 2.9 & 3.7 & 3.1 & 4.5 \\
\hline Leeds & 83 & 393 & 3.8 & 1.0 & 3.7 & 3.2 & 4.3 \\
\hline
\end{tabular}


Table 10.18. Continued

\begin{tabular}{|c|c|c|c|c|c|c|c|}
\hline Centre & $\begin{array}{c}\% \\
\text { completeness }\end{array}$ & $\begin{array}{c}\text { Number of } \\
\text { patients } \\
\text { with data }\end{array}$ & Mean & $\mathrm{SD}$ & Median & $\begin{array}{c}\text { Lower } \\
\text { quartile }\end{array}$ & $\begin{array}{c}\text { Upper } \\
\text { quartile }\end{array}$ \\
\hline Liv Ain & 60 & 67 & 3.8 & 1.0 & 3.7 & 3.0 & 4.6 \\
\hline Liv RI & 8 & 33 & & & & & \\
\hline M Hope & 72 & 220 & 3.6 & 1.0 & 3.5 & 3.0 & 4.2 \\
\hline Newc & 90 & 187 & 3.8 & 1.1 & 3.6 & 3.1 & 4.4 \\
\hline Newry & 99 & 82 & 3.9 & 1.0 & 3.7 & 3.3 & 4.5 \\
\hline Norwch & 88 & 205 & 4.1 & 1.0 & 4.0 & 3.4 & 4.8 \\
\hline Nottm & 84 & 291 & 3.8 & 1.0 & 3.6 & 3.1 & 4.3 \\
\hline Oxford & 90 & 293 & 3.8 & 1.1 & 3.7 & 3.1 & 4.4 \\
\hline Plymth & 83 & 99 & 3.9 & 0.8 & 3.8 & 3.3 & 4.5 \\
\hline Shrew & 99 & 146 & 3.9 & 1.0 & 3.8 & 3.2 & 4.5 \\
\hline Stevng & 40 & 124 & & & & & \\
\hline Sthend & 93 & 107 & 4.1 & 1.0 & 4.0 & 3.3 & 4.6 \\
\hline Stoke & 97 & 235 & 3.7 & 0.9 & 3.6 & 3.0 & 4.3 \\
\hline Sund & 97 & 143 & 3.8 & 1.0 & 3.7 & 3.1 & 4.4 \\
\hline Swanse & 98 & 270 & 3.8 & 1.0 & 3.6 & 3.0 & 4.3 \\
\hline Truro & 99 & 141 & 3.9 & 1.1 & 3.8 & 3.2 & 4.4 \\
\hline Tyrone & 97 & 69 & 4.0 & 0.9 & 3.8 & 3.4 & 4.4 \\
\hline Ulster & 100 & 74 & 4.1 & 1.0 & 4.0 & 3.4 & 4.7 \\
\hline Wirral & 86 & 147 & 3.7 & 1.1 & 3.5 & 2.9 & 4.1 \\
\hline Wolve & 96 & 244 & 3.8 & 1.0 & 3.8 & 3.1 & 4.5 \\
\hline Wrexm & 62 & 46 & 3.9 & 1.0 & 3.8 & 3.3 & 4.4 \\
\hline
\end{tabular}

Blank cells denote centres excluded from analyses due to low patient numbers or poor data completeness

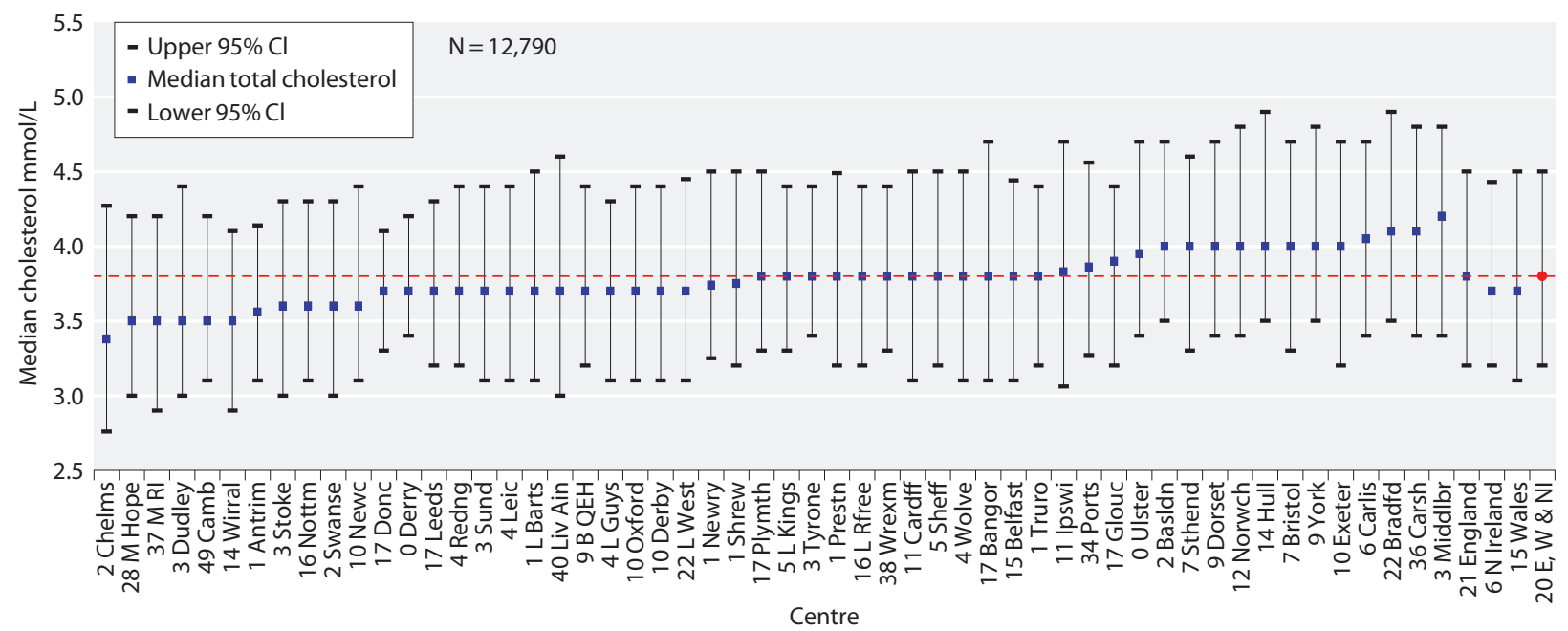

Fig. 10.41. Median total cholesterol in haemodialysis patients by centre in 2007 
Table 10.19. Summary statistics for total cholesterol in peritoneal dialysis patients in 2007

\begin{tabular}{|c|c|c|c|c|c|c|c|}
\hline Centre & $\begin{array}{c}\% \\
\text { completeness }\end{array}$ & $\begin{array}{l}\text { Number of } \\
\text { patients } \\
\text { with data }\end{array}$ & Mean & $\mathrm{SD}$ & Median & $\begin{array}{c}\text { Lower } \\
\text { quartile }\end{array}$ & $\begin{array}{c}\text { Upper } \\
\text { quartile }\end{array}$ \\
\hline B Heart & 90 & 28 & 4.5 & 1.1 & 4.3 & 3.9 & 5.3 \\
\hline B QEH & 83 & 98 & 4.2 & 1.1 & 4.2 & 3.5 & 4.7 \\
\hline Bangor & 87 & 27 & 4.8 & 1.2 & 4.8 & 3.9 & 5.5 \\
\hline Bradfd & 94 & 34 & 4.9 & 1.3 & 4.6 & 3.8 & 5.5 \\
\hline Brightn & 62 & 48 & 4.4 & 1.2 & 4.1 & 3.6 & 5.4 \\
\hline Bristol & 85 & 61 & 4.8 & 1.6 & 4.6 & 3.9 & 5.5 \\
\hline Camb & 100 & 47 & 4.2 & 1.2 & 4.2 & 3.2 & 4.8 \\
\hline Cardff & 99 & 145 & 4.6 & 1.3 & 4.5 & 3.7 & 5.3 \\
\hline Covnt & 0 & 0 & & & & & \\
\hline Derby & 49 & 35 & & & & & \\
\hline Derry & 100 & 4 & & & & & \\
\hline Donc & 24 & 8 & & & & & \\
\hline Dorset & 89 & 50 & 4.5 & 1.1 & 4.4 & 3.6 & 5.3 \\
\hline Dudley & 76 & 41 & 4.0 & 1.2 & 3.9 & 3.2 & 4.6 \\
\hline Exeter & 84 & 59 & 4.5 & 1.3 & 4.4 & 3.5 & 5.3 \\
\hline Glouc & 93 & 28 & 4.9 & 1.5 & 4.8 & 3.8 & 5.6 \\
\hline Hull & 77 & 64 & 4.9 & 1.1 & 4.8 & 4.1 & 5.7 \\
\hline Ipswi & 96 & 43 & 4.1 & 0.7 & 4.0 & 3.6 & 4.5 \\
\hline L Barts & 98 & 214 & 4.4 & 1.1 & 4.3 & 3.6 & 5.1 \\
\hline L Guys & 98 & 59 & 4.7 & 1.3 & 4.7 & 3.8 & 5.3 \\
\hline M RI & 94 & 108 & 4.1 & 1.1 & 4.2 & 3.3 & 4.8 \\
\hline Middlbr & 88 & 22 & 5.3 & 2.0 & 4.8 & 4.1 & 5.6 \\
\hline Newc & 100 & 46 & 4.4 & 1.1 & 4.3 & 3.7 & 5.2 \\
\hline Newry & 100 & 13 & & & & & \\
\hline Norwch & 96 & 55 & 4.8 & 1.3 & 4.5 & 3.8 & 5.7 \\
\hline Nottm & 93 & 126 & 4.2 & 1.0 & 4.1 & 3.5 & 4.9 \\
\hline Oxford & 86 & 115 & 4.7 & 1.2 & 4.7 & 4.0 & 5.4 \\
\hline Plymth & 84 & 32 & 4.3 & 1.1 & 4.1 & 3.6 & 4.8 \\
\hline Ports & 37 & 34 & & & & & \\
\hline Prestn & 99 & 76 & 4.5 & 1.3 & 4.2 & 3.7 & 5.1 \\
\hline Redng & 99 & 85 & 4.4 & 1.1 & 4.0 & 3.7 & 4.8 \\
\hline Sheff & 72 & 63 & 4.2 & $\begin{array}{l}1.1 \\
1.2\end{array}$ & 4.0 & 3.3 & 5.1 \\
\hline Shrew & 100 & 33 & 4.6 & 1.4 & 4.3 & 3.4 & 5.4 \\
\hline Stevng & 58 & 22 & 4.6 & 1.4 & 4.3 & 3.4 & 5.8 \\
\hline Sthend & 72 & 13 & & & & & \\
\hline Stoke & 100 & 90 & 3.7 & 1.4 & 3.7 & 2.6 & 4.6 \\
\hline Sund & 60 & 6 & & & & & \\
\hline Swanse & 97 & 72 & 4.2 & 1.2 & 4.3 & 3.5 & 4.7 \\
\hline Truro & 96 & 22 & 4.3 & 1.3 & 3.8 & 3.4 & 5.1 \\
\hline
\end{tabular}


Table 10.19. Continued

\begin{tabular}{|c|c|c|c|c|c|c|c|}
\hline Centre & $\begin{array}{c}\% \\
\text { completeness }\end{array}$ & $\begin{array}{c}\text { Number of } \\
\text { patients } \\
\text { with data }\end{array}$ & Mean & $\mathrm{SD}$ & Median & $\begin{array}{c}\text { Lower } \\
\text { quartile }\end{array}$ & $\begin{array}{c}\text { Upper } \\
\text { quartile }\end{array}$ \\
\hline Tyrone & 100 & 5 & & & & & \\
\hline Ulster & 100 & 2 & & & & & \\
\hline Wirral & 68 & 19 & & & & & \\
\hline Wolve & 79 & 42 & 4.4 & 1.2 & 4.3 & 3.7 & 5.1 \\
\hline Wrexm & 80 & 24 & 4.3 & 1.3 & 3.9 & 3.5 & 5.2 \\
\hline York & 83 & 19 & & & & & \\
\hline England & 80 & 2,661 & 4.4 & 1.2 & 4.3 & 3.6 & 5.1 \\
\hline N Ireland & 97 & 94 & 4.5 & 1.2 & 4.1 & 3.7 & 5.0 \\
\hline Wales & 94 & 276 & 4.5 & 1.2 & 4.4 & 3.6 & 5.2 \\
\hline $\mathrm{E}, \mathrm{W} \& \mathrm{NI}$ & 82 & 3,031 & 4.4 & 1.2 & 4.3 & 3.6 & 5.1 \\
\hline
\end{tabular}

Blank cells denote centres excluded from analyses due to low patient numbers or poor data completeness n/a not applicable

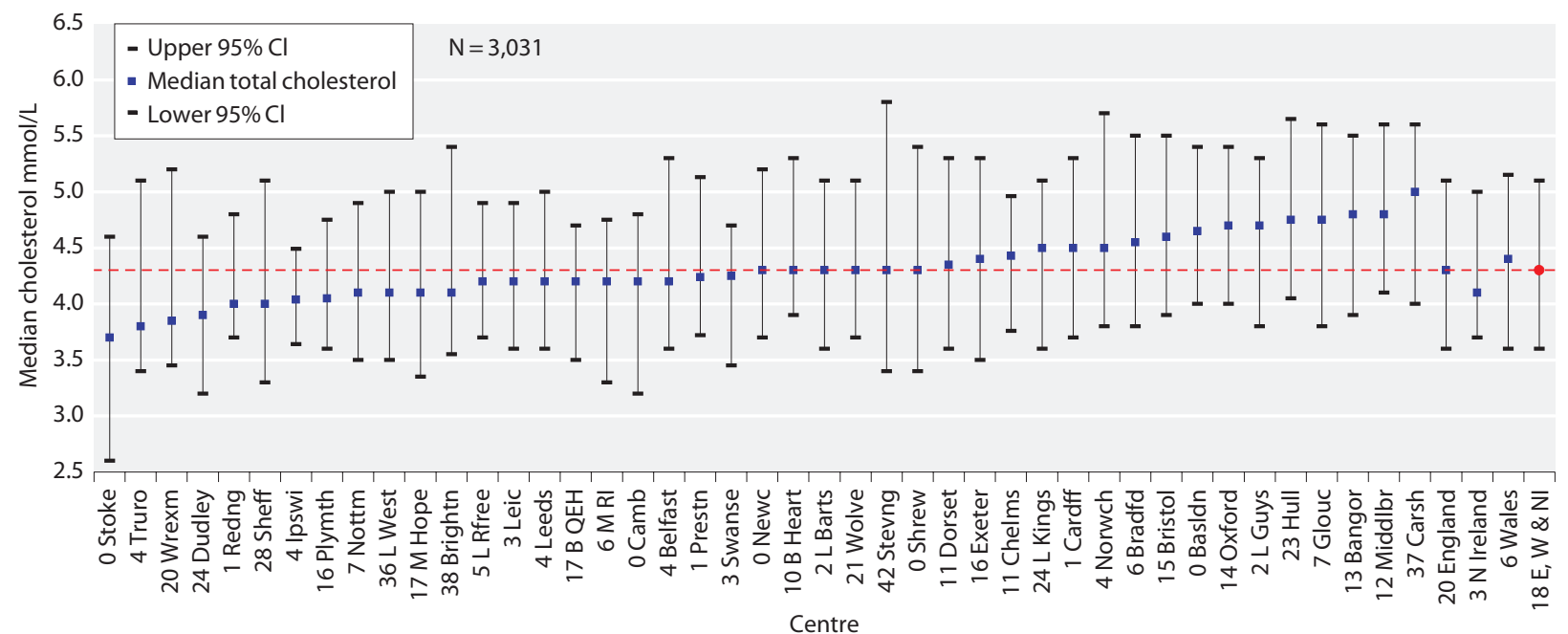

Fig. 10.42. Median total cholesterol in peritoneal dialysis patients by centre in 2007

number of case mix factors (comorbidity, inflammation, malnutrition) which may account for any inter centre variation in addition to differences in prescription of lipid lowering medication and other therapies known to influence lipid level e.g. steroids, sevelamer etc. The UKRR is planning to collect an enhanced dataset with more detailed lipid profiles and prescribing data. In conjunction with the awaited results from the SHARP trial [6] this should provide further information about optimal lipid management in UK dialysis patients.

Conflict of interest: none

\section{References}

1 Renal Association Clinical practice guidelines. 4th edition. Module 2, complications. www.renal.org/guidelines. 2007.

2 Ansell, D.F., J. Feest, T.G. Tomson, C. Williams, A.J. Warwick, G., UK Registry Report. Chapter 9 Management of biochemical variables. 2007, UK Renal Registry: Bristol UK.

3 Ansell, D.B., C. Feest, T.G., UK Renal Registry Report. Chapter 3. 2002.

4 Lamb, E.J., S. Vickery, and A.R. Ellis, Parathyroid hormone, kidney disease, evidence and guidelines. Ann Clin Biochem, 2007.44(Pt1):p.1-4.
5 National Kidney Foundation KDOQI (TM) Clinical Practice Guidelines. Available from: http://www.kidney.org/professionals/KDOQI.

6 Spiegelhalter, D.J., Funnel plots for comparing institutional performance. Stat Med, 2005.24(8):p.1185-202.

7 Kalantar-Zadeh, K., et al., Survival predictability of time-varying indicators of bone disease in maintenance hemodialysis patients. Kidney Int, 2006.70(4):p.771-80.

8 Melamed, M.L., et al., Changes in serum calcium, phosphate, and PTH 
and the risk of death in incident dialysis patients: a longitudinal study. Kidney Int, 2006.70(2):p.351-7.

9 Noordzij, M., et al., The Kidney Disease Outcomes Quality Initiative (K/DOQI) Guideline for Bone Metabolism and Disease in CKD: association with mortality in dialysis patients. Am J Kidney Dis, 2005.46(5): p.925-32.

10 Stevens, L.A., et al., Calcium, phosphate, and parathyroid hormone levels in combination and as a function of dialysis duration predict mortality: evidence for the complexity of the association between mineral metabolism and outcomes. J Am Soc Nephrol, 2004.15(3):p.770-9.

11 Block, G.A., et al., Mineral metabolism, mortality, and morbidity in maintenance hemodialysis. J Am Soc Nephrol, 2004.15(8):p.2208-18.

12 Danese, M.D., et al., Consistent Control of Mineral and Bone Disorder in Incident Hemodialysis Patients. Clin J Am Soc Nephrol, 2008.2:p.2.

13 Ansell, D.F., T.G. (eds), Renal Registry 7th Annual Report. In chapter 6: Adequacy of haemodialysis and serum bicarbonate. 2004.p.59-86. 
